\title{
Large Mining Blasts from the Kursk Mining Region, Russia
}

W. Leith

V. Adushkin

A. Spivak

January 1997

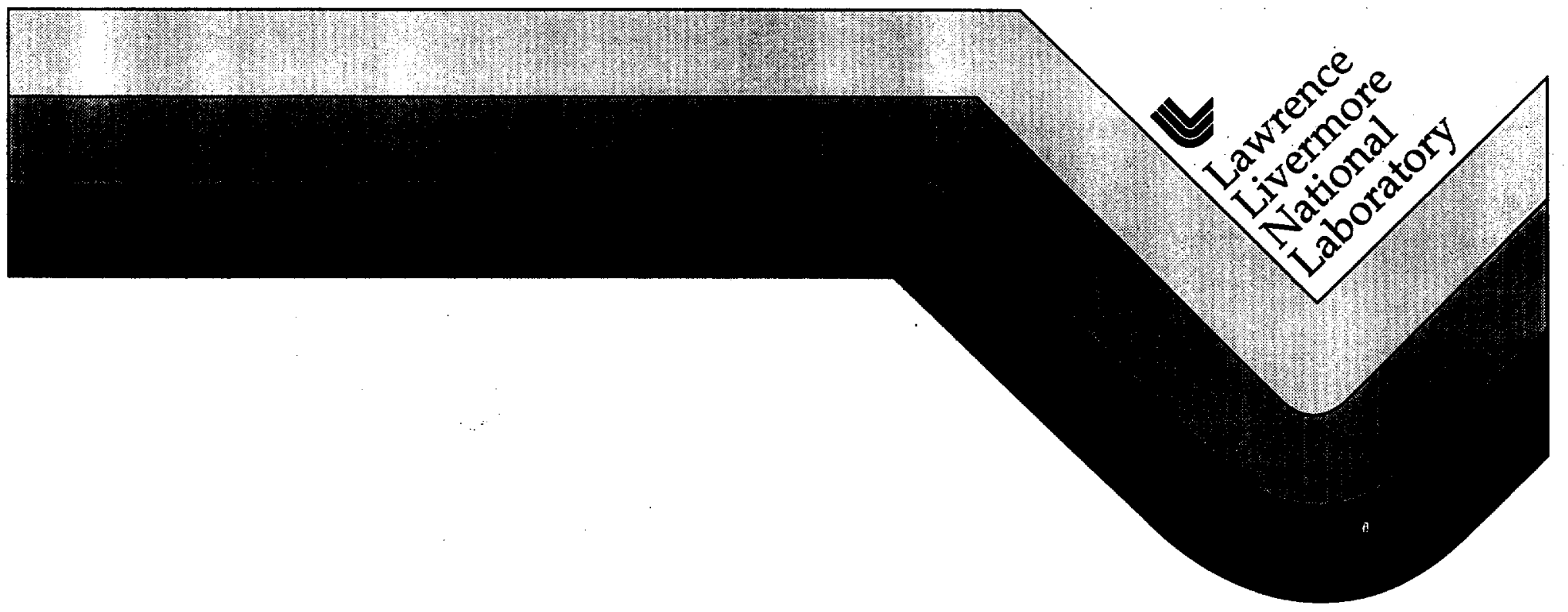




\section{DISCLAIMER}

This document was prepared as an account of work sponsored by an agency of the United States Government. Neither the United States Government nor the University of California nor any of their employees, makes any warranty, express or implied, or assumes any legal liability or responsibility for the accuracy, completeness, or usefulness of any information, apparatus, product, or process

disclosed, or represents that its use would not infringe privately owned rights. Reference herein to any specific commercial product, process, or service by trade name, trademark, manufacturer, or otherwise, does not necessarily constitute or imply its endorsement, recommendation, or favoring by the United States Government or the University of California. The views and opinions of authors expressed herein do not necessarily state or reflect those of the United States Government or the University of California, and shall not be used for advertising or product endorsement purposes. 


\title{
Large Mining Blasts from the Kursk Mining Region, Russia
}

\author{
William Leith \\ U.S. Geological Survey \\ Reston VA 22092 \\ Vitaliy Adushkin and Alexander Spivak \\ Institute of the Dynamics of Geospheres \\ Moscow, Russia
}

\section{Table of Contents}

Introduction: Mining Blasts as Seismic Events under a CTBT $\ldots \ldots \ldots \ldots \ldots \ldots$

Blasting in the Former Soviet Union $\ldots \ldots \ldots \ldots \ldots \ldots \ldots \ldots \ldots \ldots \ldots$

Mining in the Kursk Magnetic Anomaly $\ldots \ldots \ldots \ldots \ldots \ldots \ldots \ldots \ldots \ldots$

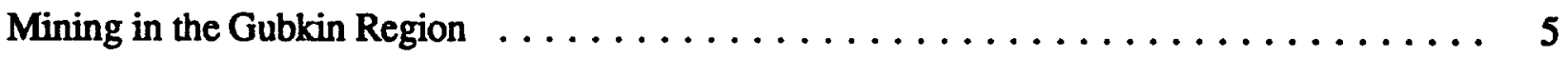

Geologic Setting of the Mines at Gubkin $\ldots \ldots \ldots \ldots \ldots \ldots \ldots \ldots \ldots \ldots$

Blasting Practices at the Kursk Mines $\ldots \ldots \ldots \ldots \ldots \ldots \ldots \ldots \ldots \ldots \ldots, 10$

Large Blasts at the Lebedinsky Combine in $1992 \quad \ldots \ldots \ldots \ldots \ldots \ldots \ldots \ldots$

Two types of Blasting $\ldots \ldots \ldots \ldots \ldots \ldots \ldots \ldots \ldots \ldots, 12$

Detailed Example of a Blast from $1994 \ldots \ldots \ldots \ldots \ldots \ldots \ldots \ldots \ldots \ldots, 12$

Charge-time Data $\ldots \ldots \ldots \ldots \ldots \ldots \ldots \ldots \ldots \ldots \ldots \ldots \ldots \ldots, 14$

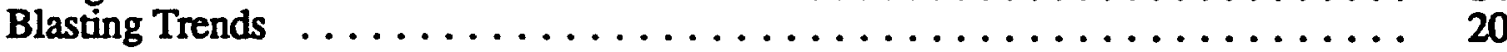

Seismic Recordings of Blasts, August-September, $1995 \ldots \ldots \ldots \ldots \ldots \ldots \ldots 20$

Mine Blast Sources, Stations and Instrumentation $\ldots \ldots \ldots \ldots \ldots \ldots \ldots, 20$

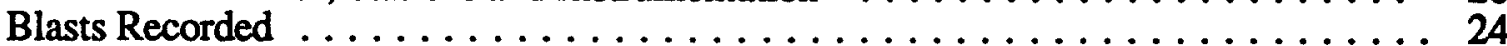

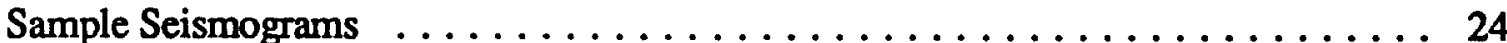

Magnitude Determinations $\ldots \ldots \ldots \ldots \ldots \ldots \ldots \ldots \ldots \ldots \ldots \ldots \ldots \ldots \ldots, 24$

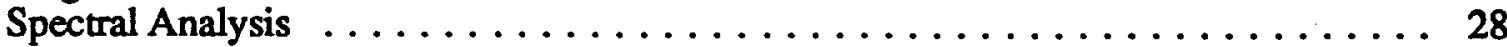

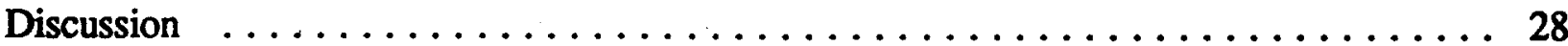

Acknowledgements $\ldots \ldots \ldots \ldots \ldots \ldots \ldots \ldots \ldots \ldots \ldots \ldots \ldots \ldots \ldots \ldots \ldots \ldots \ldots$

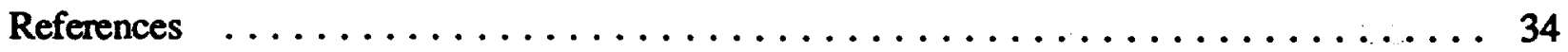

Appendix 1: Catalog of Mining Explosions at Lebedinsky GOK, 1992-1995 . . . A1-1

Appendix 2: Explosives Commonly Used in Russia and the former Soviet Union A2-1

Appendix 3: Charge-time data for blasts at Lebedinsky and Gubkin. . . . . . . A3-1

Appendix 4: Video/movie of the detonation of a single block from the blast of

September 7, 1995, at Lebedinsky GOK. ................. A4-1

Appendix 5: Seismograms for blasts recorded in Aug.-Sep., 1995. . . . . . . . A5-1

Appendix 6: Nomogram used for determining the magnitudes of the Kursk

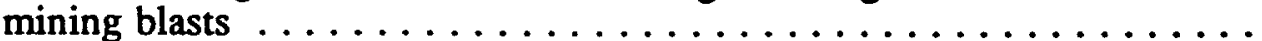




\section{Introduction: Mining Blasts as Seismic Events under a CTBT}

Monitoring the Comprehensive Nuclear Test Ban Treaty (CTBT) by seismic means will require identification of seismic sources at magnitude levels where industrial explosions (primarily, mining blasts) may comprise a significant fraction of the total number of events recorded, and may for some countries dominate the seismicity. Thus, data on blasting practice have both political significance for the negotiation of treaties involving seismic monitoring of nuclear tests, and operational applications in terms of establishing monitoring and inspection needs on a mine-by-mine basis.

While it is generally accepted that mining explosions contribute to seismicity at lower seismic magnitudes (less than about magnitude 3.5), the rate of mining seismicity as a function of seismic magnitude is unknown for most countries outside the U.S. This results in a large uncertainty when estimating the task of discriminating nuclear explosions from chemical explosions and earthquakes, by seismic means, under a comprehensive nuclear test ban. This uncertainty directly affects estimates of seismic network enhancements required to achieve treaty verification requirements at magnitudes less than about 3.5.

\section{Blasting in the Former Soviet Union}

Before its breakup in 1991, the former Soviet Union (FSU) conducted most of the largest known chemical explosive blasts (for a review of blasting in the former Soviet Union, see Leith and Bruk, 1995a). While the largest of those blasts (up to 13kt) were rare explosions for excavation projects (principally dam building), the mining industry of the FSU routinely detonated blasts in excess of $1 \mathrm{kt}$. The FSU is a leading producer of many commodities mined with explosives, including iron ore. The principal mining regions in the FSU are shown on the map of Figure 1. The Kursk region was, in 1987, the second largest iron ore producing region in the former Soviet Union (next to Krivoy Rog, Ukraine), and accounted for about $10 \%$ of world iron ore production and $20 \%$ of Soviet iron ore production.

Table 1 lists the major, non-coal mining districts in the former Soviet Union that conducted very large blasts (those with total charge exceeding 300 tons). The numbers of large blasts are significantly larger than is estimated for the United States (see data for US explosions in 1987 in Richards and others, 1992), including the US coal-mining industry, which detonates the most of the largest blasts in terms of total charge size. Note that the Kursk mining combines (see below) are prominent on this list, reflecting the large production of iron ores from the Kursk region.

\section{Mining in the Kursk Magnetic Anomaly}

The city of Kursk is located in the center of a broad belt of banded iron ore deposits in European Russia, some $400 \mathrm{~km}$ south of Moscow (Figure 2). The region is known geologically as the Kursk Magnetic Anomalies (or KMA), because of the strong magnetic anomaly pattern generated by the magnetized iron ore deposits. While the 


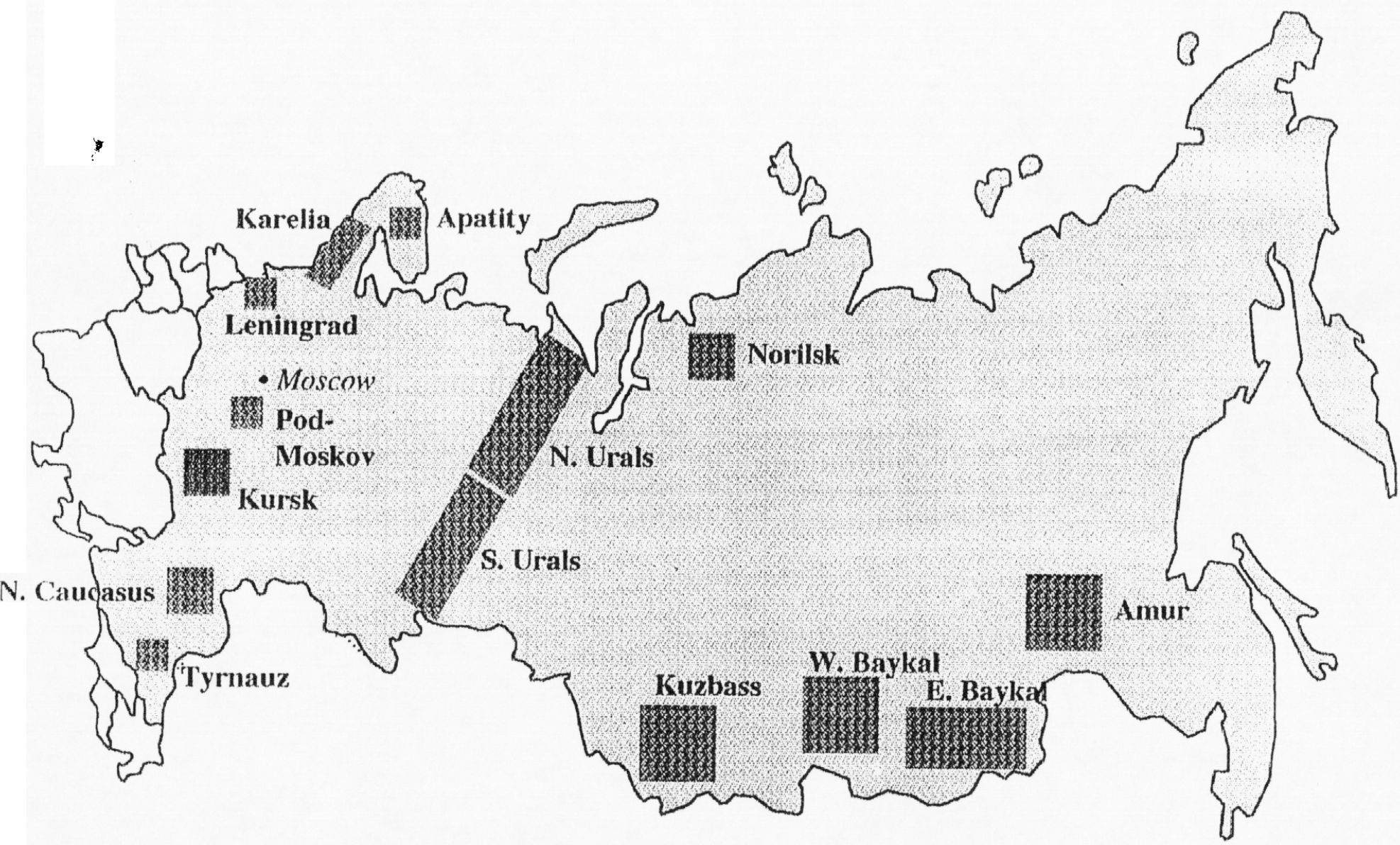

Figure 1. Map of the Russian Federation, showing the principal regions using "strong" more than 300 ton) mining blasts in Russia in 1993. Within each of these regions operate several mining-metallurgical combines, or GOKs. Thur Kursk mining region is located south of Moscow, near the Ukranian border. 


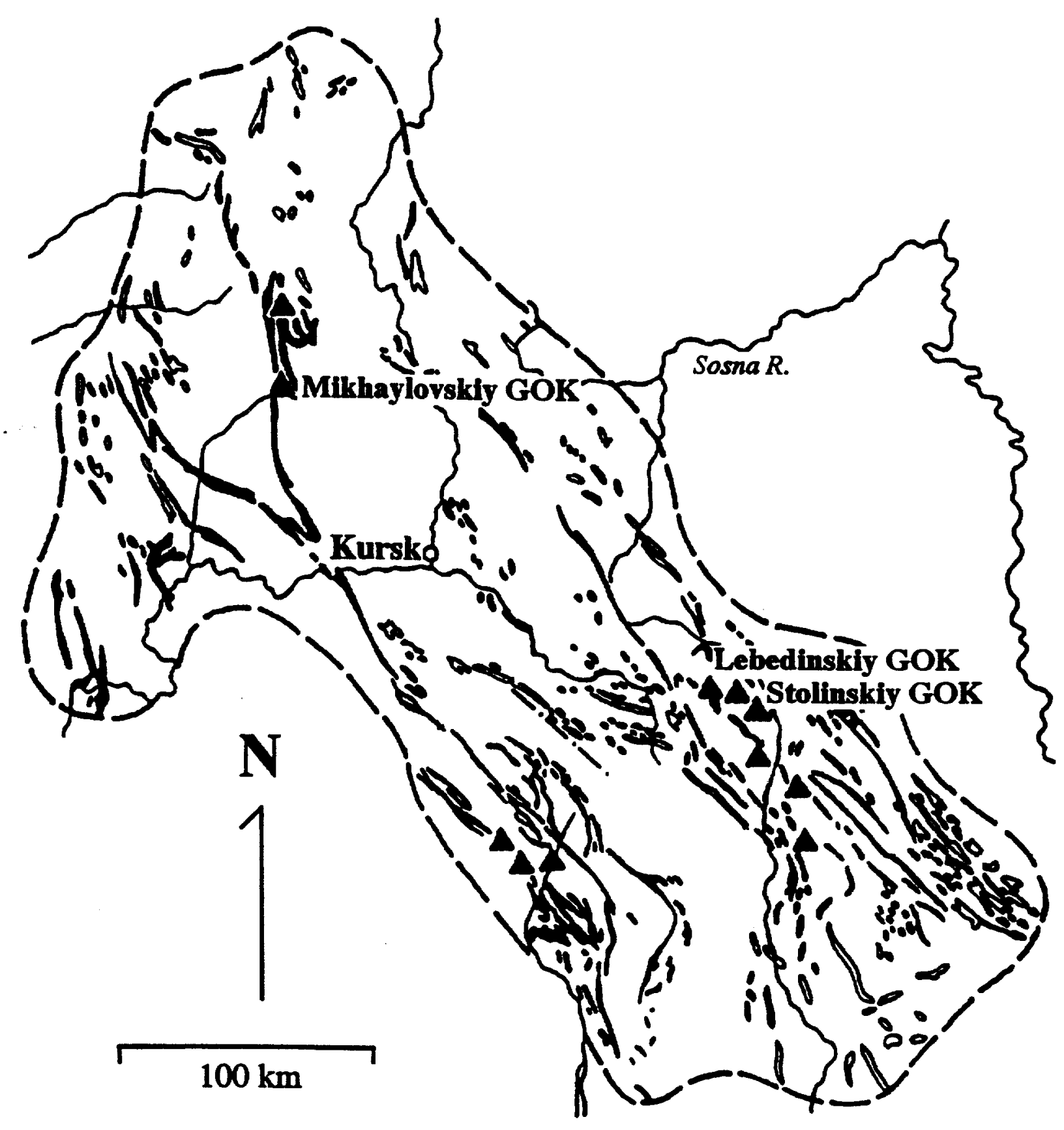

Figure 2. Map of the Kursk region, showing the distribution of banded iron formation (filled bands are higher grade iron ore; unfilled bodies are lower grade ore) and the locations of the principal mining combines (triangles). Note the locations of the Lebedinsky, Mikhaylovsky, and Stolylensky mining/metallurgical combines (GOKs). 
KMA were discovered in 1778, the iron ore deposits were completely covered by sediments ranging from 37 to 500 meters thick. Geophysical studies began in 1883, and the first cores of banded iron formation were recovered in 1923 (Alexandrov, 1973).

Table 1. Preliminary Data on Large Mining Blasts in the Former Soviet Union. Data are for the year 1988.

\begin{tabular}{|c|c|c|c|}
\hline Mining Region & $\begin{array}{l}\text { largest group } \\
\text { tot. charge size }(t)\end{array}$ & $\begin{array}{l}\text { approximate no. } \\
\text { no. per year }\end{array}$ & commodity (note) \\
\hline Norilsk & up to 1500 & rare & $\mathrm{Cu}, \mathrm{Ni}$ \\
\hline Kursk (L)* & $300-1500$ & 50 & $\mathrm{Fe}$ \\
\hline Udachnaya & $>1000$ & 50 & Diamond \\
\hline Krivoy Rog & $>1000$ & N/A & $\mathrm{Fe}$ \\
\hline Tyrniauz & $<1000$ & N/A & Mo \\
\hline Dzhezkazgan & $500-600$ & 50 & $\mathrm{Cu}$ \\
\hline Kursk (M)* & $100-500$ & 50 & $\mathrm{Fe}$ \\
\hline Apatity & $>400$ & $0-10$ & Apatite \\
\hline Kursk (S)* & $50-500$ & 50 & $\mathrm{Fe}$ \\
\hline Aykhal & N/A & $25-30$ & Diamond \\
\hline
\end{tabular}

* M, Mikhaylovsky combine; L, Lebedinsky combine; S, Stolylensky combine.

The KMA cover an area of about 170,000 square kilometers. There are two principal belts of banded iron formation; one to the southwest of the city of Kursk, the Belgorod belt; the other to the northeast of Kursk, the Oskol' belt. Several of the ore bodies have enormous dimensions: for example, the Yakovlevo deposit, in the Belgorod region, has been traced more than 50 kilometers along strike, ranging in width from 200 to 400 meters in thickness. The reserves of iron in the KMA are estimated to be 13 times that of Krivoy Rog, the next largest iron reserve of the former Soviet Union (in Ukraine), and almost 17 times larger than those of the Lake Superior region in the U.S. and Canada (Alexandrov, 1973).

\section{Mining in the Gubkin Region}

Mines conducting "strong" blasts (over 300 tons) in the region of the Kursk Magnetic Anomaly are limited to the surface mines at the Lebedinsky, Mikhaylovsky 
and Stolylensky Mining and Metallurgical Combines (see Table 1). Blasting at these mines is carried out in the open cast method, in deep surface excavations 1. As seen in Table 1, the Lebedinsky and Mikhaylovsky mines have dominated the largest charge sizes of Soviet blasts, and are therefore of interest as targets for seismic monitoring research.

\section{Geologic Setting of the Mines at Gubkin}

Iron-bearing quartzites in the region of Gubkin (a.k.a. Stariy Oskol) form an elongated massif, extending up to $3 \mathrm{~km}$ in length in a southwest-northeast direction. Within this massif, there are three areas of minerals exploitation, known as Central, Southern and Stoylo-Lebedinsky. The iron ores are reached by removing a cover of sedimentary rocks (as at the Lebedinsky and Stoylensky mines) or by constructing a shaft through the cover rocks (as a Gubkin/Stariy Oskol). A Russian, 1:200,000-scale map of the Gubkin-Stariy Oskol' region is shown in Figure 3.

Detailed geologic information is available for the Lebedinsky open-pit mine (see photograph in Figure 4). At Lebedinsky, cover rocks are represented by (from top to bottom):

$\begin{array}{ll}\text { loam and clay } & 1-20 \mathrm{~m} \\ \text { marly-chalky strata } & 0-60 \mathrm{~m} \\ \text { sand layers (Cenomanian-Albian) } & 25-30 \mathrm{~m} \\ \text { sandy-clayey deposits (Jurassic) } & \begin{array}{l}2.5-27 \mathrm{~m} \\ \text { clays and ore-bearing breccias }\end{array} \\ \begin{array}{r}\text { (Devonian) in depressions } \\ \text { in the Precambrian surface }\end{array} & \text { variable } \\ \end{array}$

The iron-bearing quartzites consist of quartz, alkaline amphibole, and cummingtonite. The ore-bearing minerals are magnetite and specularite (specular iron); secondary minerals include carbonates, biotite, feldspar, aegerine, garnet, pyrite, and apatite. The amount of non-ore-bearing shales within the layers of iron-quartzites is $1.2 \%$, with thicknesses ranging from 0.1 to 3.0 meters; their vertical thickness can reach 5-10 meters in steeply-dipping beds. Low-iron quartzites comprise $1.85 \%$.

The deposits of iron quartzites are characterized by a complex alternation of rocks of varying petrography and structure; this complexity results in a large water flow into boreholes that are drilled for loading explosives. The hardness of the quartzites in the apex of the folds is more than 20 on the Schmidt scale; the axial compressive strength on laboratory samples exceeds $200 \mathrm{MPa}$.

A geological cross-section is shown in Figure 5.

1 Underground mines also exist at throughout the KMA, for instance at Gubkin and Stariy Oskol (see Figure 3). Blast data from these mines is also presented in this report. 
FINAL REPORT--USGS/UC-LLL MOA B291532

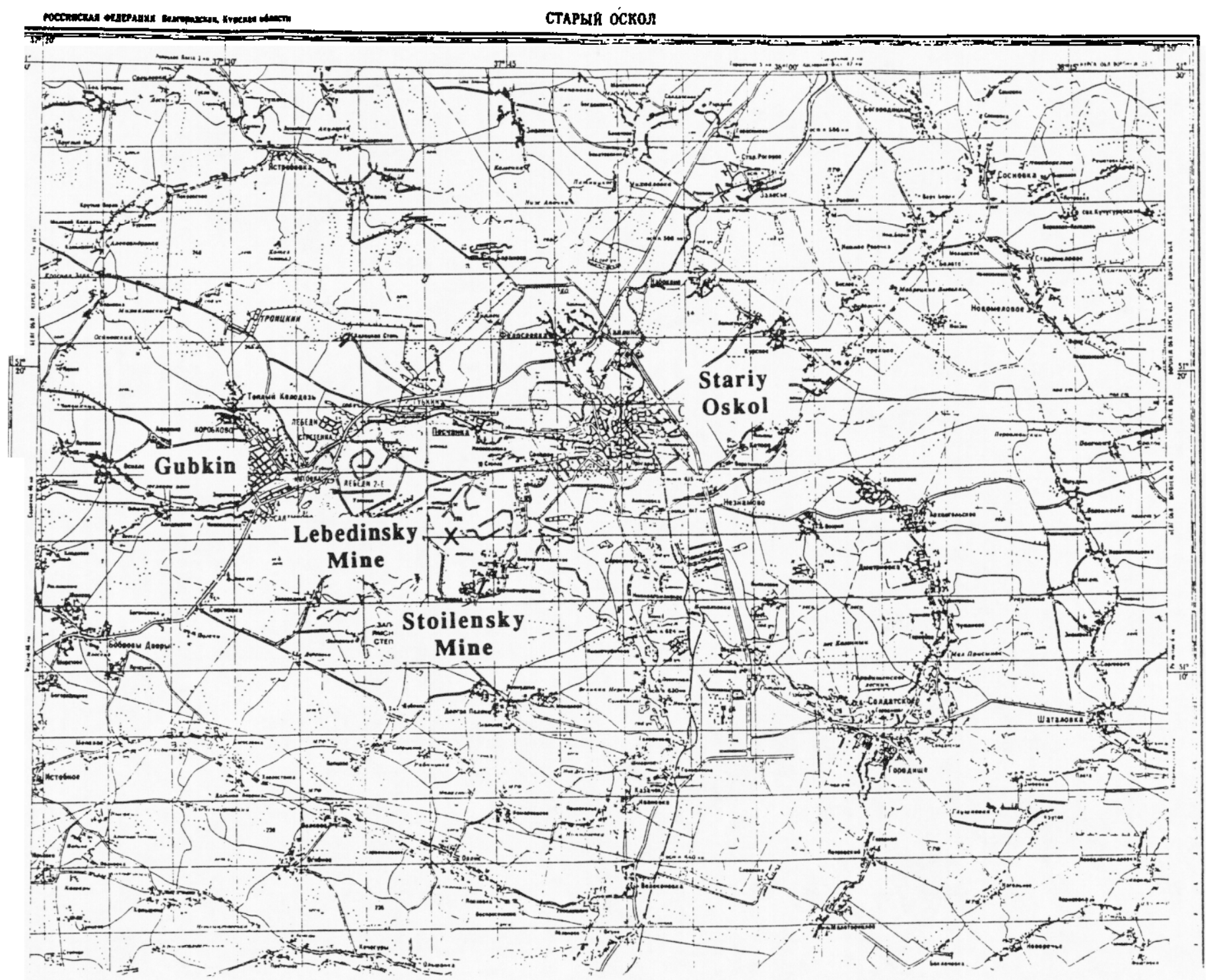

Figure 3. Map of the Gubkin (Stariy Oskol) region (portion of the Russian, 1:200,000 topographic map), showing the locations of the Lebedinsky and Stoylensky open-pit mines and the towns of Gubkin and Stariy Oskol, where underground mining is conducted. 


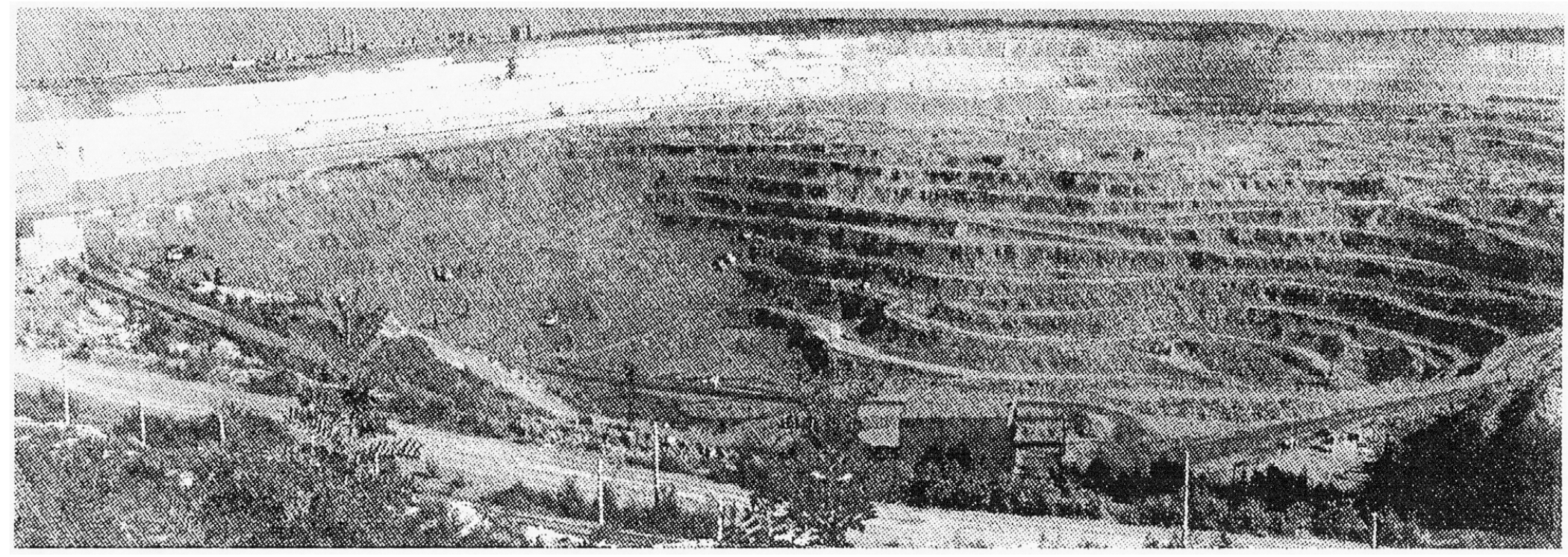

Figure 4. Photo-mosaic of the open pit mine at Lebedinsky. The light-colored, upper layers are a cover of Quaternary and Cretaceous sedimentary rocks (see text), overlying the iron ore-bearing quartzites of banded iron formation. The cover rocks are about 100 meters thick. 


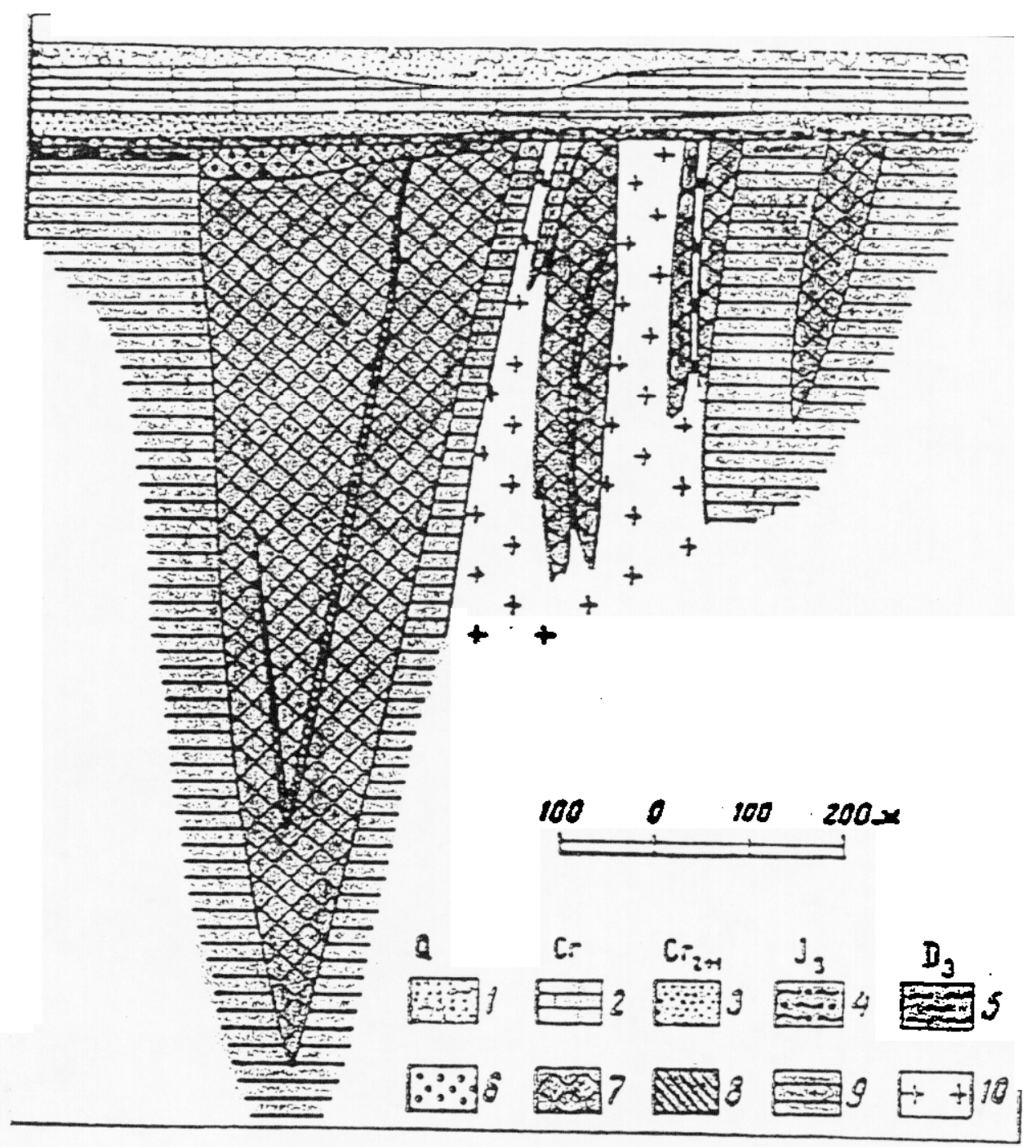

Figure 5. Geological cross-section of the Lebedinsky iron ore deposit, Kursk mining , region (from Laznika, 1993). The thick cover layers have been stripped back to expose the iron ores for surface mining. These deposits are also mined nearby in underground workings, at significant depths. Key as follows: 1) soils; 2) marl; 3) sandtone; 4) clay with sandstone interbeds; 5) claystone with sandstone interbeds; 6) iron ores in the weathered layer; 7) banded iron formation (Proterozoic); 8) schists; 9) schist, meta-quartzite and gneiss; 10) diorite porphyrite. 


\section{Blasting Practices at the Kursk Mines}

Table 2 gives statistics for strong blasts at the Kursk mines in 1993. It is not known how much variability there is in blasting practices at these mines over periods of years, but comparison with Table 1 indicates that blast size and frequency have dropped since the 1980s. Blasting has been further diminished at Kursk in the last few years as a result of deteriorating economic conditions. This has resulted in both lower total charge sizes and some weeks or months passing without blasts.

Table 2. Total numbers of blasts and "strong" blasts (those with total charges of 300 tons or more) at Kursk in 1993.

\begin{tabular}{llcc} 
mining combine & total charge & total blasts & blasts $\geq 300 \mathrm{t}$ \\
\cline { 3 - 4 } Lebedinsky & $250-1400 \mathrm{t}$ & 34 & 30 \\
Mikhaylovsky & $200-500 \mathrm{t}$ & 50 & 40 \\
Stolylensky & $100-700 \mathrm{t}$ & 25 & 12
\end{tabular}

\section{Large Blasts at the Lebedinsky Combine in 1992}

In recent years, the Lebedinsky combine has detonated the largest blasts in the Kursk region. As noted above, blasting here is conducted in surface mines by the open cast method, in mines cut relatively deep through the surface deposits. Note that this mine is also located in close proximity to active, deep underground mine workings at Gubkin, and is therefore an ideal target for a seismological mine monitoring experiment.

The blasts are composed of a series of blocks, spatially separated across the open pit mine. These blocks are ripple-fired (discussed below), with delays of one or more seconds between them. The principal explosives used are granulotol and grammonite; a list of explosives commonly used in Russia and the former Soviet Union, and their TNT equivalents, is given in Appendix 2. Figure 6 is a map of the Lebedinsky mine, showing the blocks detonated in series on September 7,1995. Block maps for other blasts at Gubkin are given in Appendix 3. The video/movie of Appendix 4 shows the detonation of a single block of the blast of September 7,1995, at the Lebedinsky mine.

Table 3 lists large blasts detonated at the Lebedinsky Combine during the first six months of 1992. Several features of these blasts are worth noting. First, most of the blasts were detonated on alternate Thursdays, and all but two were detonated at 12:00 or 12:30pm, local time. This pattern of regular blast timing at a single mining combine is typical of Russian blasting practice, and has been noted at several of the largest Russian mines (e.g., Apatity, Tyrnauz, Kuzbass, and others). 
Figure 6. Sketch map of the pit at Lebedinsky mine, showing the distribution of charge blocks for the blast of September 7,1995.




Table 3. Blasts at Lebedinsky mining combine, Feb-Jun, 1992

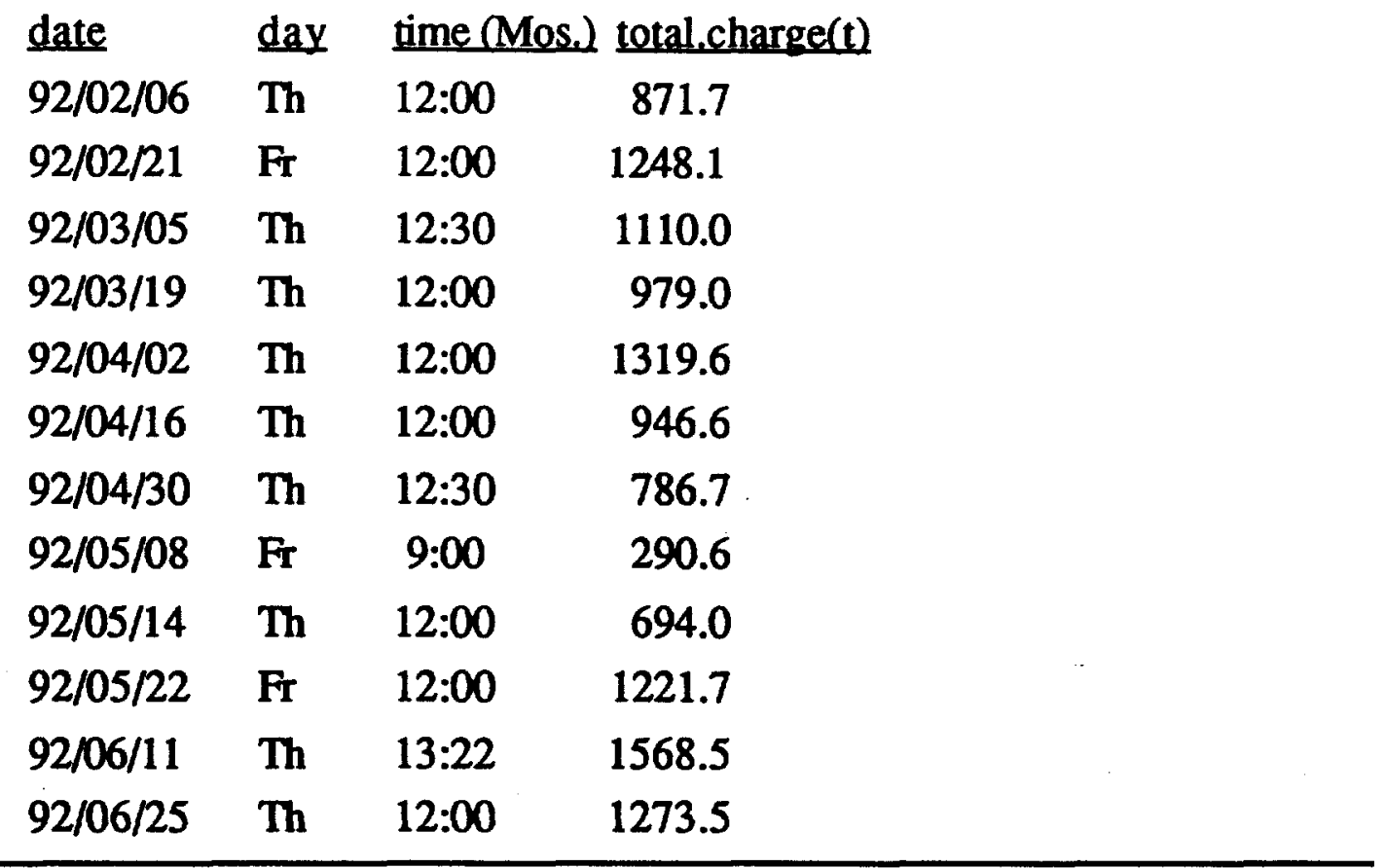

\section{Two types of blasting}

Blasts at Kursk have traditionally been conducted using a "conventional" geometry, in which an entire row of spaced charges is detonated at once (Figure 7a). This method, which is very efficient at crushing and displacing the rock but results in large amplitude ground motion near the source, has dominated the blasting at Kursk for decades. This type of blasting is now apparently only rarely used in the United States because of damage to structures near mines as a result of the near-source ground motion. Detailed blasting data for mines in the Magadan Oblast' of the Russian Far East, for the years 1989-1992 indicate that this blasting pattern was exclusively used for mining in this region, which includes both coal and metal mining (Leith and Bruk, 1995b).

In the last 1-2 years, the Kursk mines have started to use a second method or geometry, which we will call "reduced-shaking", in which individual rows are blasted in a series of charge-delayed holes. In the Russian application of this method at Kursk, charges are fired so that short, diagonally oriented rows are fired sequentially, each consisting of only a few holes (see Figure $7 b$ ). This is similar, but not identical to common U.S. "ripple-fire" blasting practices, and results in a much decreased local ground motion. By 1994, both blasting geometries were being used for mining iron ore at the Kursk mining combines.

\section{Detailed Example of a Blast from 1994}

Table 4 list the blast parameters from a large, complex blast that was detonated at 
$\mathbf{a}$
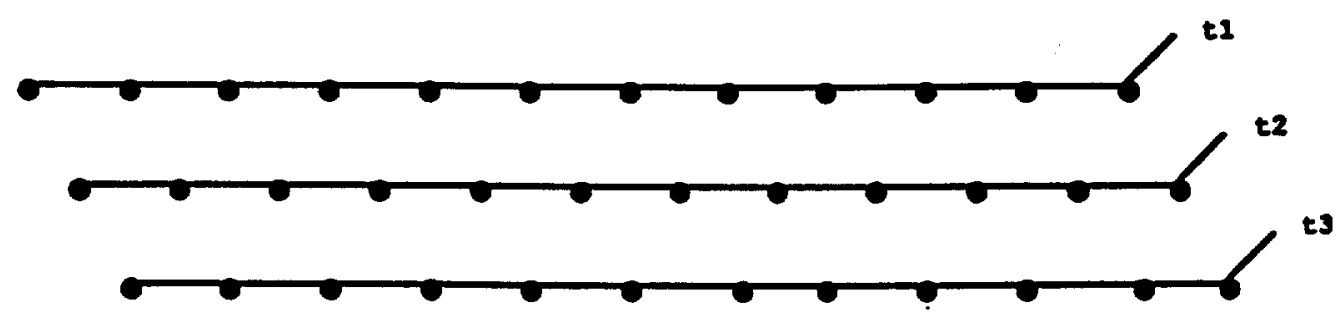

b

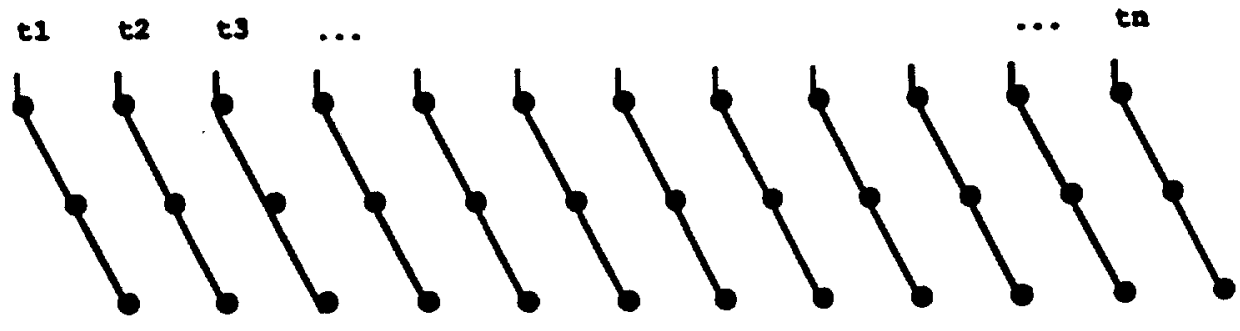

Figure 7. Typical blast geometries: a. Charge/delay geometry of a typical "conventional" mining blast, in which successive charge rows are detonated with no delay along the row. b. Charge/delay geometry of a "reduced shaking" blast, in which charge rows are detonated on the diagonal, down the rock face, with a short (e.g., 10 msec) delay between rows. 
the Lebedinsky mining combine in 1994 . In this blast, which was detonated at $12: 00 \mathrm{pm}$ on Tuesday, 16 August, 1994, 318 tons were detonated in five individual "blocks", separated laterally by 500 to 1000 meters. Each block was blasted in a conventional charge geometry (see above), and there was a delay of about 1 second between each block. A diagram of one block's charge geometry is shown in Figure 8).

Table 4. Charge geometry for a single block of the 18 Aug. 1994, blast at Lebedinsky combine, KMA mining region.

$\begin{array}{ll}\text { charge rows } & 3 \\ \text { hole diameter } & 250 \mathrm{~mm} \\ \text { holes per row } & \sim 38 \\ \text { charge per hole } & 560 \mathrm{~kg} \\ \text { charge per row } & \sim 21 \mathrm{t} \\ \text { hole depth } & 16.5 \mathrm{~m} \\ \text { charge length } & 12 \mathrm{~m} \\ \text { row separation } & 8 \mathrm{~m} \\ \text { hole separation } & 5 \mathrm{~m} \\ \text { delay interval } & 35 \mathrm{msec} \\ \text { delays per block } & 3 \\ \text { charge per block } & \sim 64 \mathrm{t}\end{array}$

\section{Charge-time Data}

Surface blasting. Charge-time data for two blasts at Lebedinsky mine are given in Figures 9 and 10. As described above, the blasts are detonated as a series of blocks, with groups of holes in each block detonated simultaneously, separated by delays of $20-50$ milliseconds. The total charge detonated in a single delay ranges from less than one-half ton to more than 9 tons. The detonation of a single block takes approximately 1-2 seconds, and the entire blast sequence may occur over more than 20 seconds. Data on the total charge per block is available for blasts from July, 1994 through September, 1995, listed in Appendix 1 .

Underground blasting. Charge-time data for six blasts in the underground mines at Gubkin are given in Table 5. The underground blasts are also detonated as groups of holes, separated by delays of $20-25$ msec. While the total charge and the charge per delay are smaller, as expected, it is noted that in the majority of these blasts, some 4 tons or more of explosive is detonated simultaneously --similar to the charges per delay in the surface mines. Figure 11 plots all six underground blasts on the same time scale, so that the variability in their charge-time patterns can be more easily compared. 


\begin{tabular}{rr|}
\hline \multicolumn{2}{|c|}{ 5-Aug-95 } \\
\hline time. msec & $\frac{\text { charge. } \mathrm{kg}}{1634}$ \\
20 & 3311 \\
40 & 2794 \\
60 & 4342 \\
80 & 4257 \\
100 & 4316 \\
125 & 1979 \\
150 & 2313 \\
175 & 163 \\
& 25109 \\
$\mathrm{~kg}$
\end{tabular}

\begin{tabular}{|rr|}
\hline \multicolumn{2}{|c|}{ 12-Aug-95 } \\
\hline ime. msec & charge. kg \\
0 & 413 \\
20 & 1652 \\
40 & 2013 \\
60 & 1248 \\
80 & 1660 \\
100 & 1239 \\
125 & 2082 \\
150 & 1265 \\
175 & 1222 \\
200 & 774 \\
225 & 1396 \\
& $14964 \mathrm{~kg}$
\end{tabular}

\begin{tabular}{|rr|}
\hline \multicolumn{2}{|c|}{ 19-Aug-95 } \\
\hline ime. msec & charge. kg \\
0 & 146 \\
20 & 194 \\
40 & 1445 \\
60 & 1771 \\
80 & 1668 \\
100 & 1669 \\
125 & 1136 \\
150 & 766 \\
175 & 335 \\
& $9130 \mathrm{~kg}$
\end{tabular}

\begin{tabular}{|rr|}
\hline \multicolumn{2}{|c|}{ 26-Aug-95 } \\
\hline ime. msec & charge. kg \\
0 & 129 \\
20 & 636 \\
40 & 2211 \\
60 & 3020 \\
80 & 3557 \\
100 & 4120 \\
125 & 3483 \\
150 & 4464 \\
175 & 4205 \\
200 & 2548 \\
\hline & 28373
\end{tabular}

break of 2-3 minutes

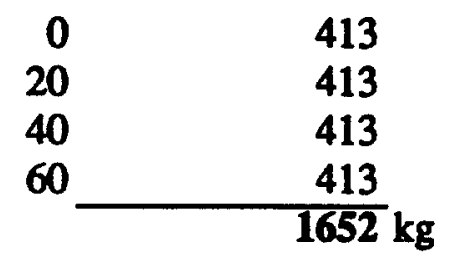

break of 25 minutes

$\begin{array}{rr}0 & 3732 \\ 25 & 1118 \\ 50 & 1945 \\ 75 & 731 \\ 100 & 584 \\ 125 & 197 \\ & \mathbf{8 3 0 7} \mathbf{~ k g}\end{array}$

Table 5. Blasting patterns for six underground blasts conducted at Gubkin in August, 1995 Note that two blasts were conducted on the days of Aug. 19 and Aug. 26 


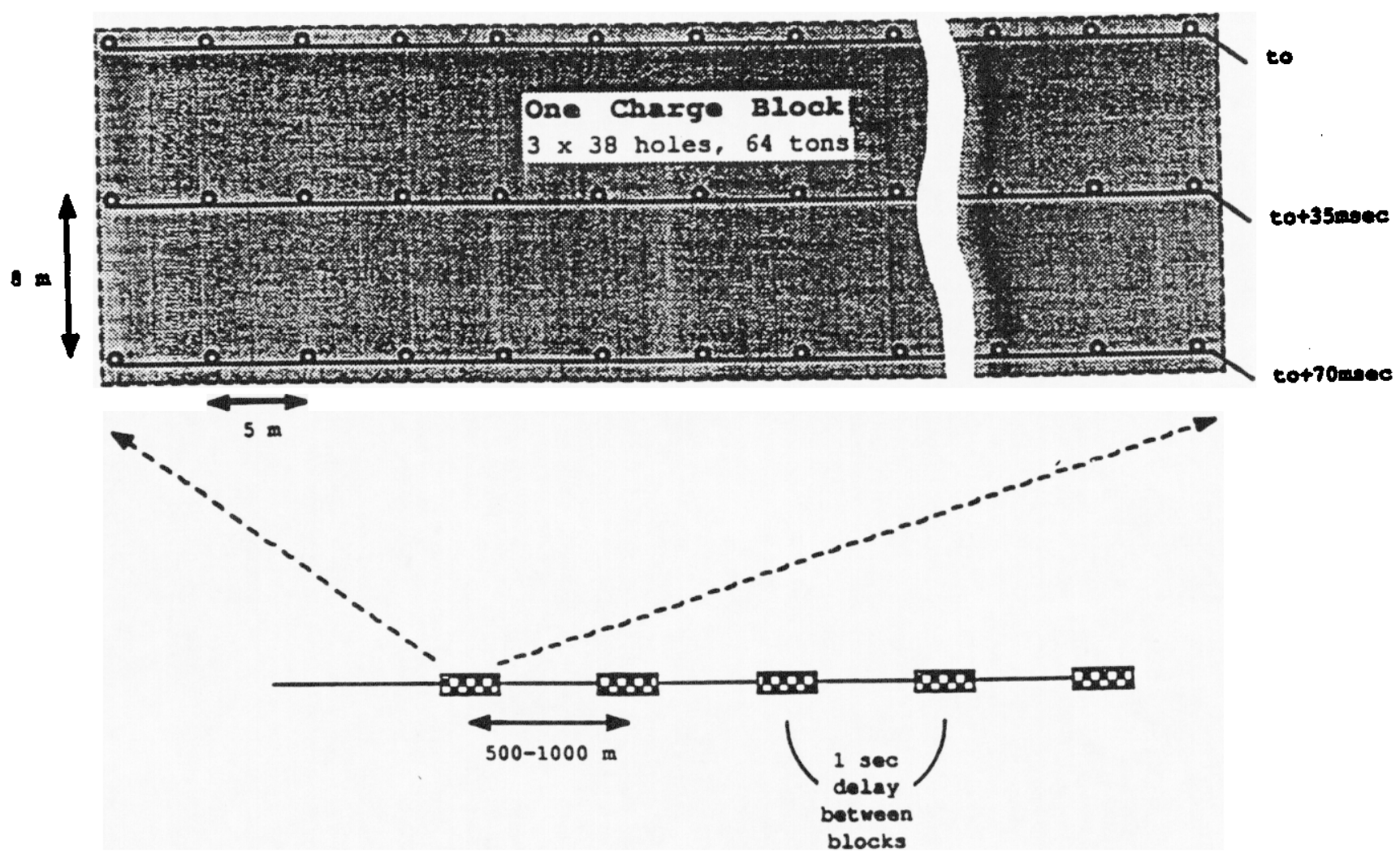

Figure 8. Example of the detailed charge geometry for a single block of the 18 Aug. 1994 blast at Lebedinsky combine, KMA mining region, Russia. This blast was composed of a series of 5 such charge blocks, each separated by 500-1000 meters, and detonated with a delay of about 1 second. 
Lebedinsky Mine, 10 Aug. 1995, 568 tons

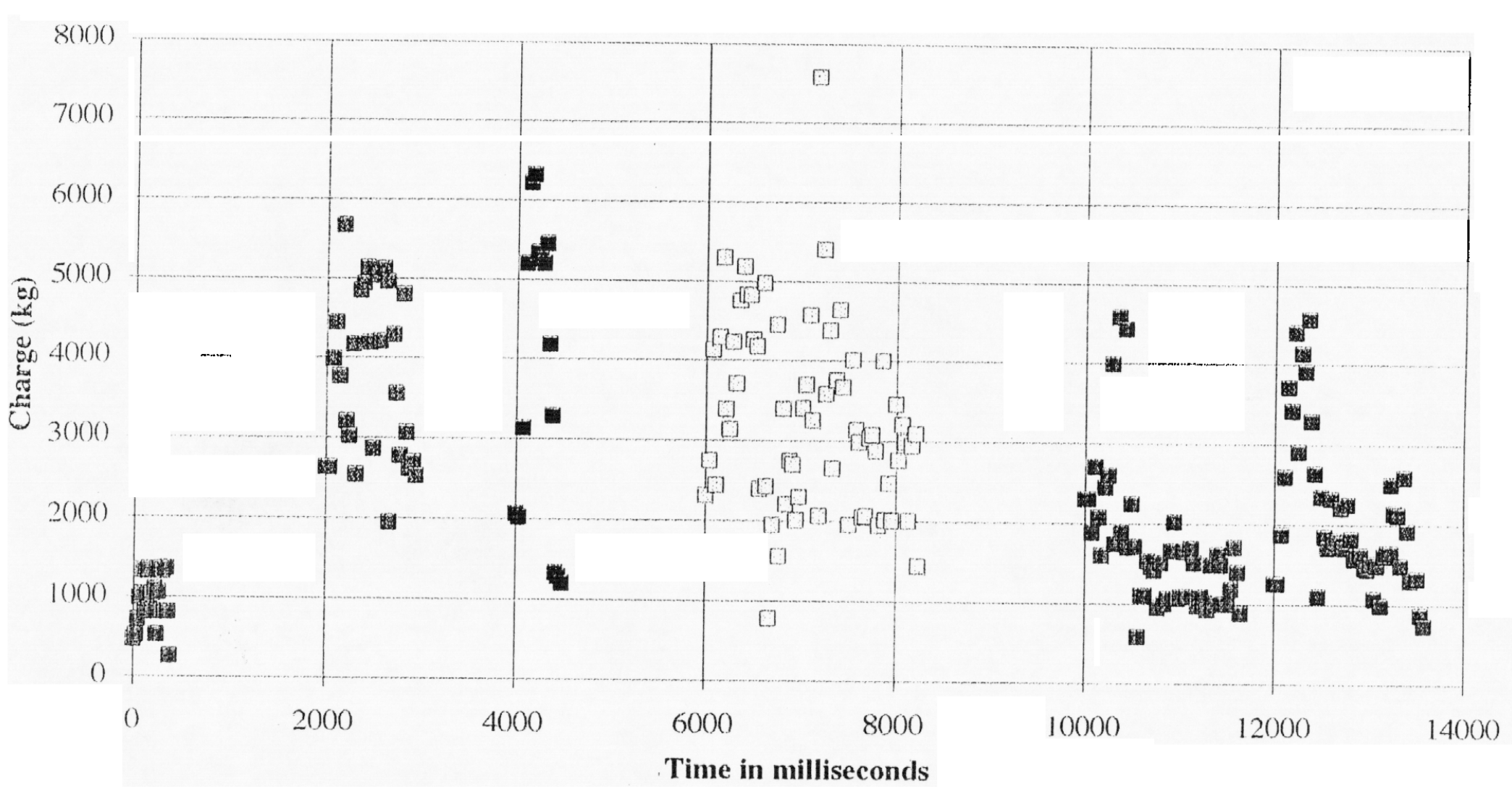

Figure 9. Firing pattern (charge-per-delay) of the blast at Lebedinsky mine on 10 August, 1995. 
Lebedinsky Mine, 24 Aug. 1995, 745 tons

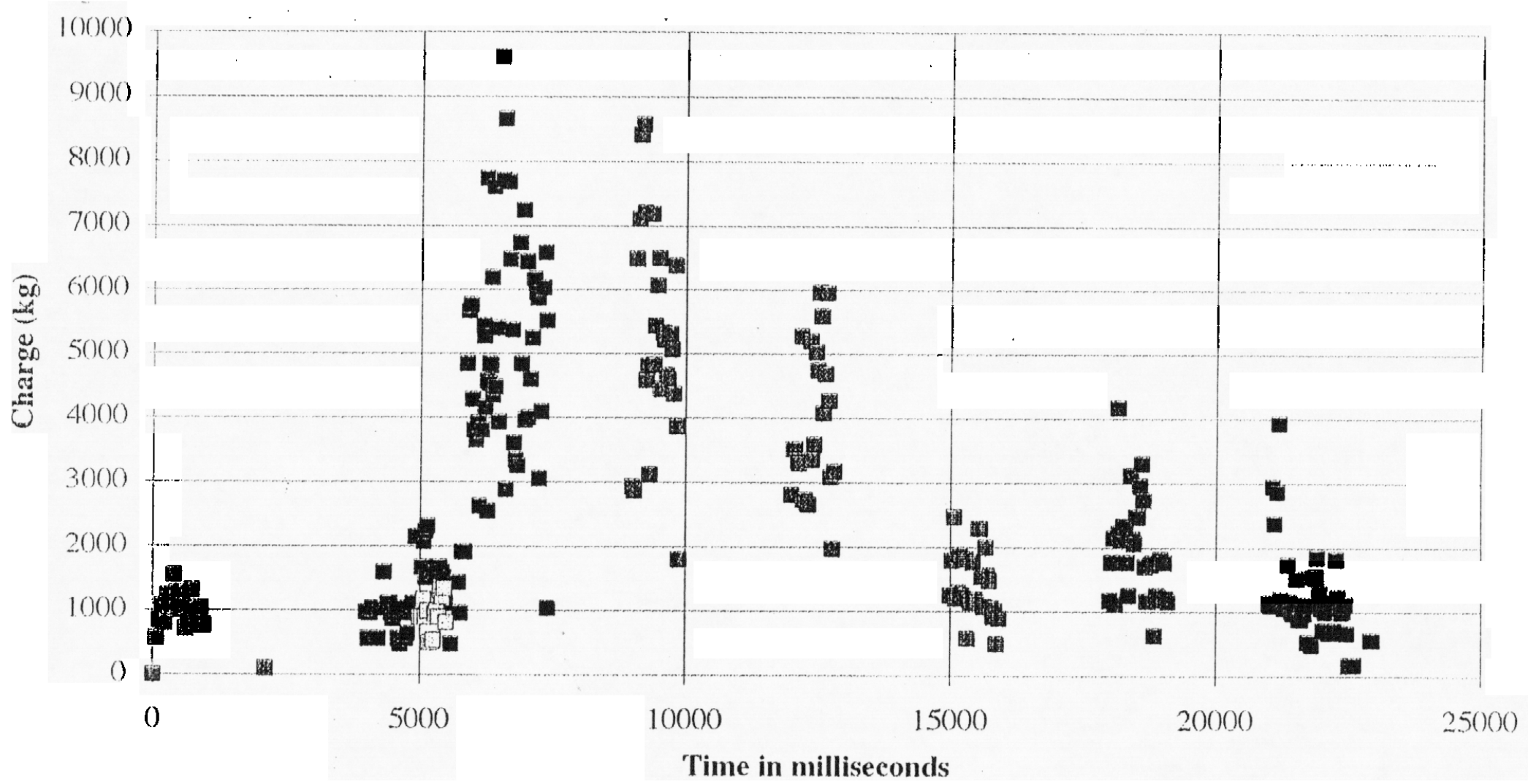

Figure 10. Firing pattern (charge-per-delay) of the blast at Lebedinsky mine on 24 August, 1995. 
Underground Blasts at Gubkin in August, 1995

$\vec{b}$

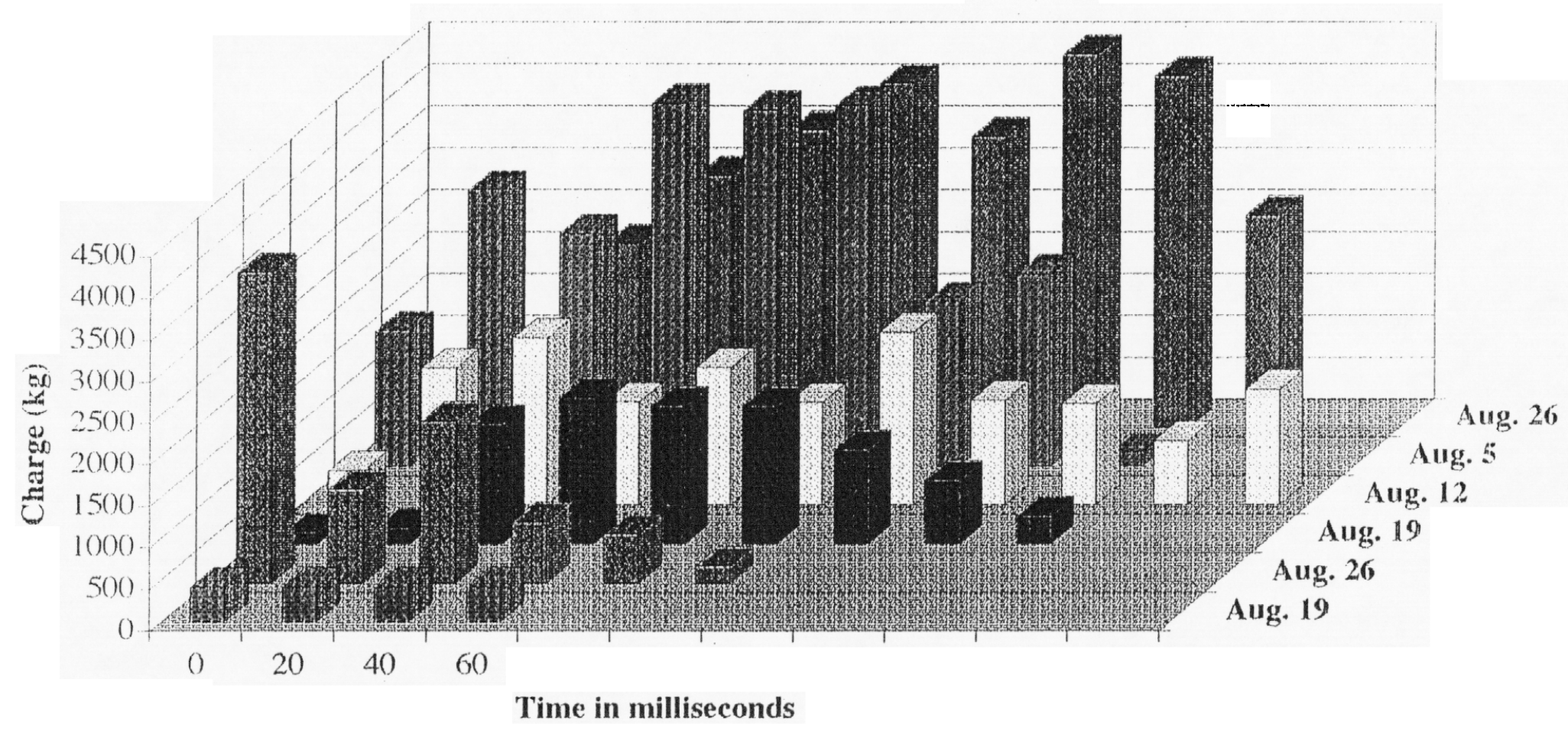

Figure 11. Firing pattern (charge-per-delay) of six blasts detonated at the underground mine at Gubkin. Note that, despite these blasts being detonated underground, there are still trhee to four metric tons of explosives being fired in a single delay, similar to the open pit mines. 


\section{Blasting Trends}

It is well known that, since the breakup of the former Soviet Union, economic conditions have deteriorated, affecting most of the major industries. This has included the mining industry, where production has fallen dramatically since 1990 . Likewise, the consumption of explosives has also fallen: In 1990, approximately 2 million metric tons of explosives were detonated in Russia; by 1994, than number had fallen to about 700,000 metric tons. Economic conditions have affected blasting practices through the unavailability (or high cost) of explosives, and has resulted in both fewer blasts and smaller total charge sizes.

There is also apparently a trend to reduce the local seismic shaking at some mines, as evidenced by the used of the "reduced shaking" blasting geometry for some of the blasts at the Lebedinsky combine. It is not known whether this is becoming more common at other mines, for mining other mineral commodities, and whether its use will soon dominate the mining industry in populated areas of Russia.

\section{Seismic Recordings of Blasts, August-September, 1995}

\section{Mine Blast Sources. Stations and Instrumentation}

Blasts detonated in August and September, 1995, were recorded from the open pit mines at Mikhaylovsky, Lebedinsky and Stoylensky GOKs, and from the underground mines at Gubkin (see map of Figure 12 for mine and station locations). These were recorded at the permanent FDSN station at Mykhnevo (MHV), as well as at an array of portable stations at various regional distances from 60 to $250 \mathrm{~km}$ from the mines. These included a digital seismic recording station at Svoboda, about mid-way between the Mikhaylovsky mine and the three mines near Gubkin (see Figure 1), and five analog seismic recording sites, at Elets, Turdey, Lamskoe, Bolshoye Ogarevo, and Tim. Coordinates of the mines and seismic recording sites are given in Table 6, and plotted on Figure 12.

Blasts were recorded on three-component, Russian, short-period seismometers (No. SM-3KV). A photograph of the seismometers is shown in Figure 13. Examples of the amplitude-frequency response of four of the instruments are given in Figures 14 and 15. Blasts recorded at Svoboda were digitized on a REFTEK Data Acquisition System and recorded to tape. Blasts recorded at the other portable stations were recorded in analog format on TEAC recording systems. Blasts recorded at Mykhnevo were recorded on multiple seismometer and system types, including a broadband digital seismic system operated jointly by the Russian Academy of Sciences and a German institute.

\section{(continues)}

Figure 12 (next page). Map of the region between Moscow and Kursk, Russia, showing the locations of the major iron-ore mines (Mikhaylovsky, Lebedinsky and Stoylensky), the permanent seismic stations at Obninsk (OBN) and Mykhnevo (MHV), and the portable seismic station sites used in this study (red triangles, named). 


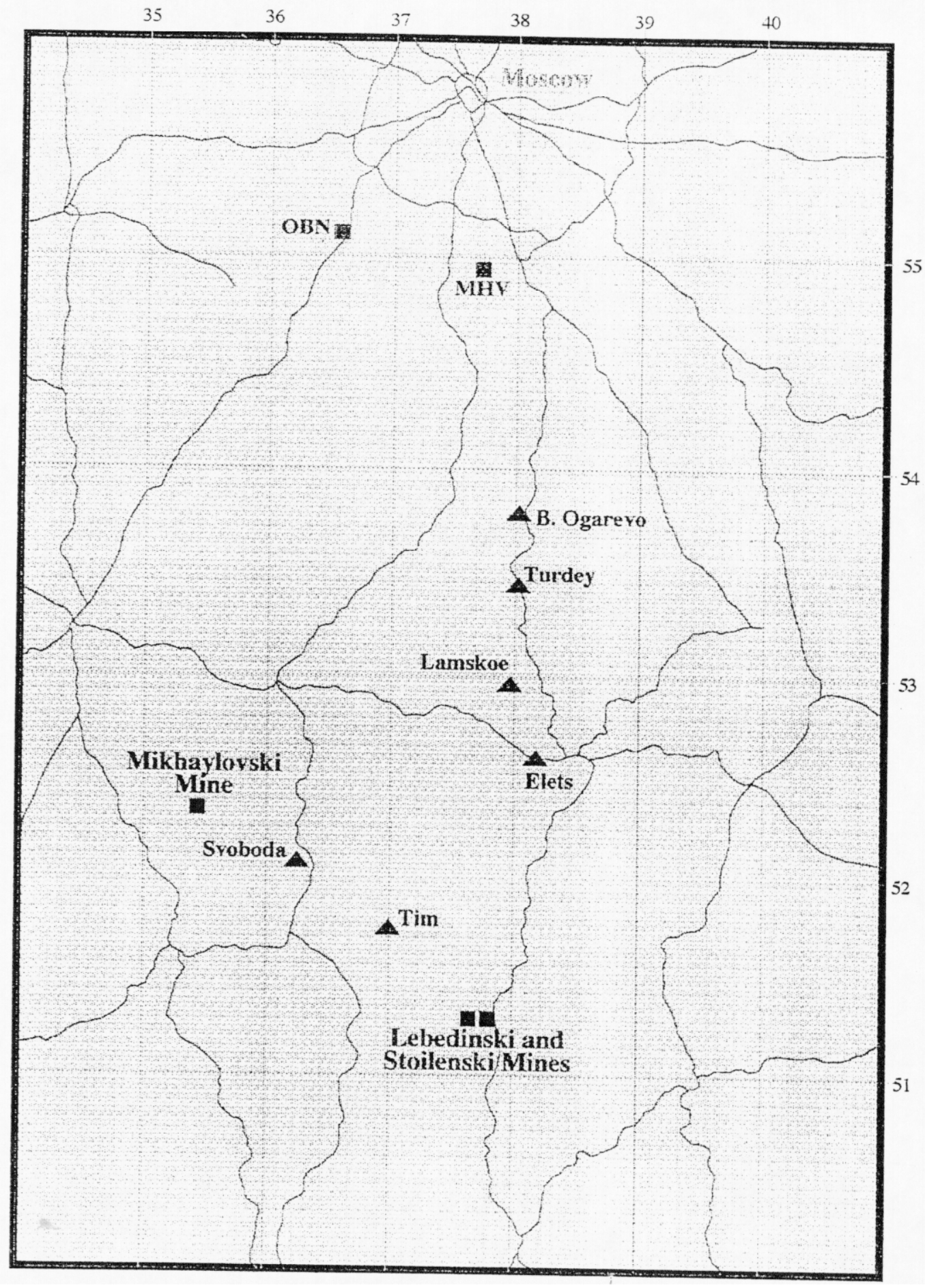

Figure 12 (caption previous page) 
FINAL REPORT--USGS/UC-LLL MOA B291532

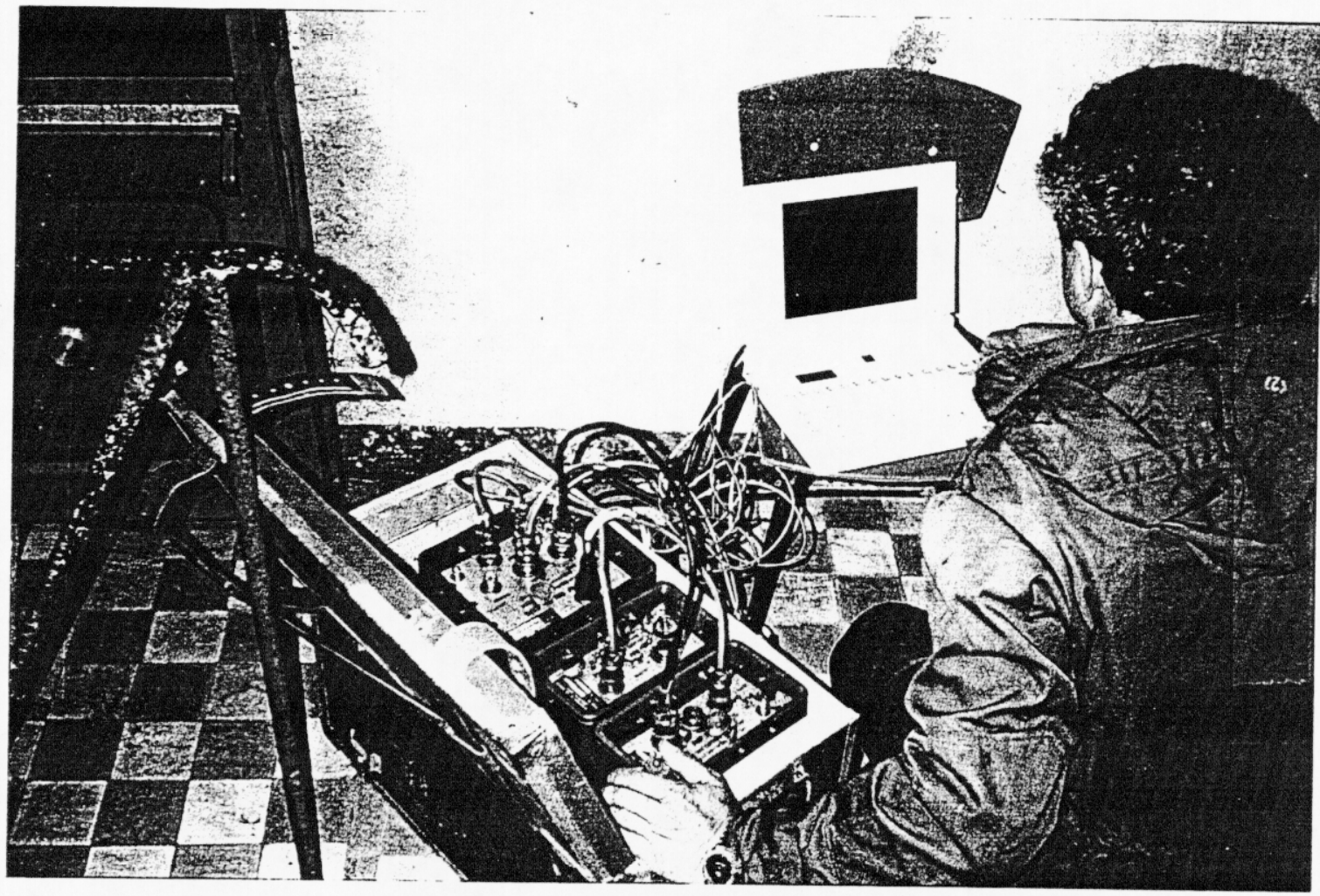

Figure 13. Photograph the REFTEK digital seismic recording system that was deployed at Svoboda, being tested in the vault at Mykhnevo. 
FINAL REPORT--USGS/UC-LLL MOA B291532

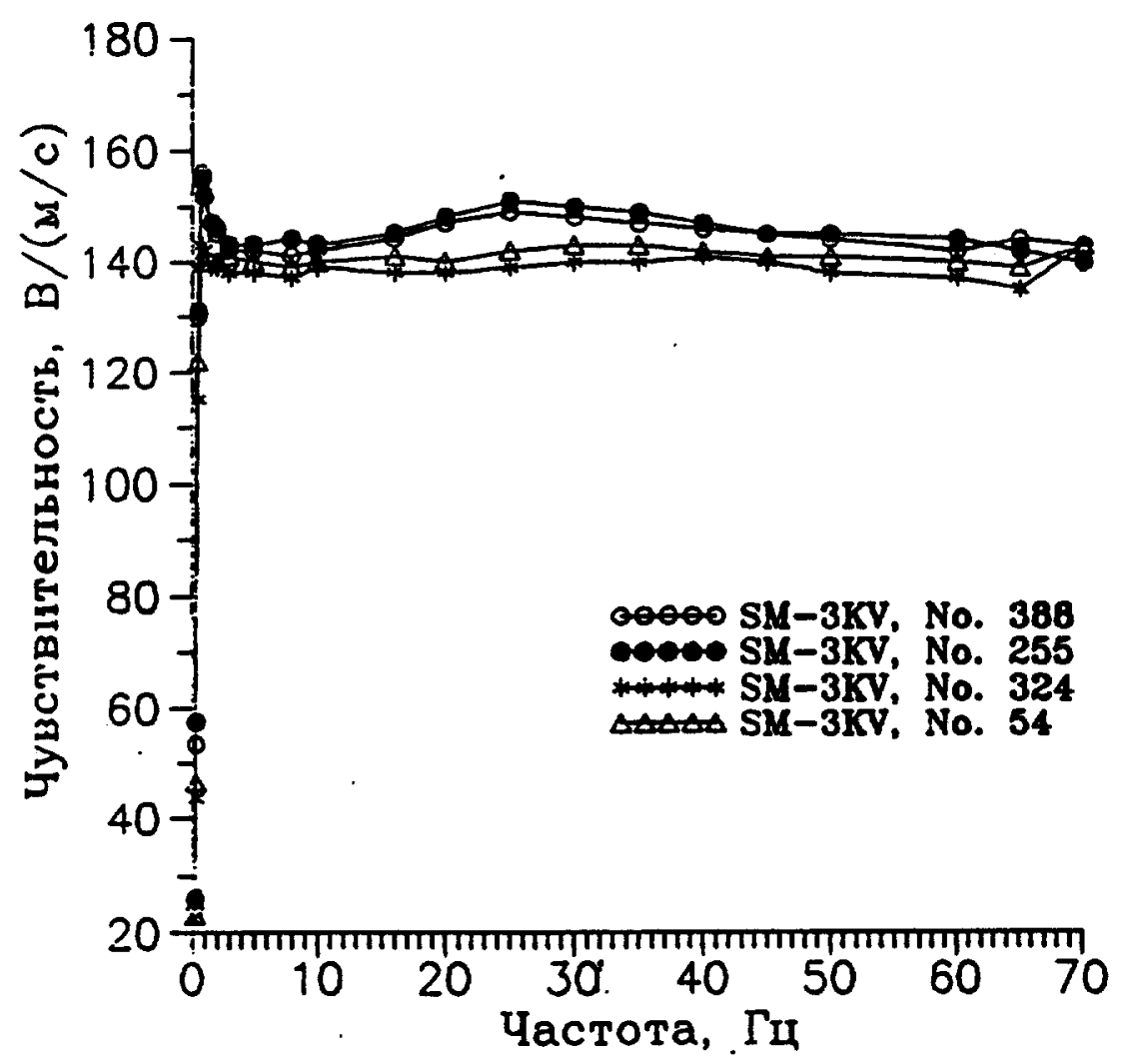

Figure 14. Sample amplitude-frequency characterisitcs of four of the SM3KV seismometers that were deployed at all portable seismic station sites.

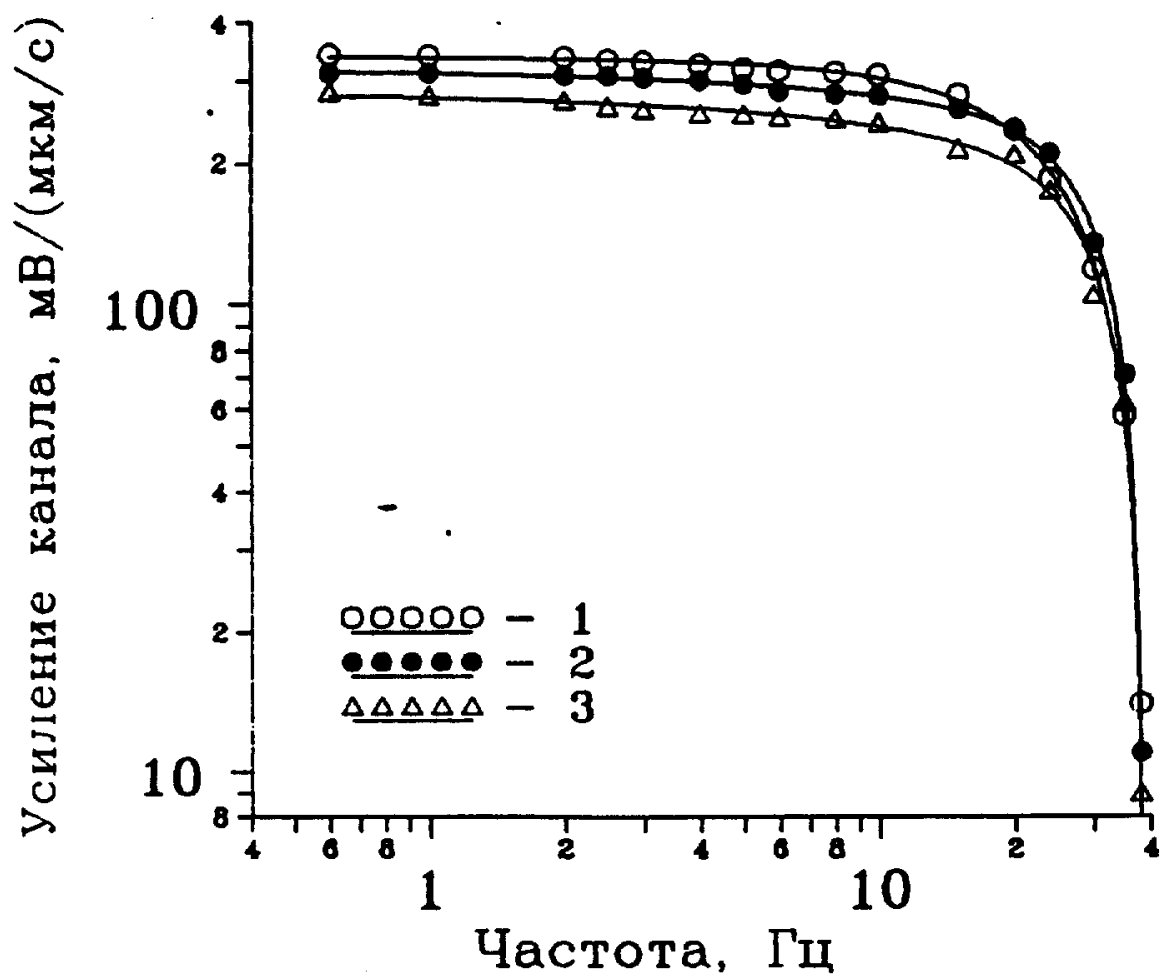

Figure 15. Magnification curves for the for the SM3KV short-period seismometers. 
Table 6. Approximate Mine and Station Coordinates

\begin{tabular}{lllllll} 
Mine Name & $\begin{array}{l}\text { Latitude } \\
\text { deg }\end{array}$ & \multicolumn{2}{l}{$\begin{array}{l}\text { Longitude } \\
\text { deg }\end{array}$} & $\underline{\text { min }}$ & $\begin{array}{l}\text { Source of } \\
\text { Coord. }\end{array}$ \\
Mikhaylovsky & 52 & 22 & & 35 & 27 & $1: 200 k$ map \\
Lebedinsky & 51 & 15 & 37 & 40 & $1: 200 k$ map \\
Stoylensky & 51 & 15 & 37 & 45 & $1: 200 k$ map \\
Gubkin & 51 & 20 & 37 & 50 & $1: 200 k$ map
\end{tabular}

\begin{tabular}{|c|c|c|c|c|c|c|}
\hline \multirow{2}{*}{$\frac{\text { Code }}{\text { OBN }}$} & \multirow{2}{*}{$\begin{array}{l}\text { Station } \\
\text { Location } \\
\text { Obninsk }\end{array}$} & \multicolumn{2}{|c|}{$\begin{array}{l}\text { Latitude } \\
\text { deg min }\end{array}$} & \multicolumn{2}{|c|}{$\begin{array}{l}\text { Longitude } \\
\text { deg min }\end{array}$} & \multirow{2}{*}{$\begin{array}{l}\text { Source of } \\
\text { coord. } \\
\text { station book }\end{array}$} \\
\hline & & 55 & 1820 & 36 & 3412 & \\
\hline MHV & Mykhnevo & 54 & 5749.4 & 37 & 4559.5 & GPS \\
\hline & Elets & 52 & 37 & 38 & 30 & gazetteer \\
\hline & Tm & 51 & 37 & 37 & 07 & gazetteer \\
\hline & Svoboda & 51 & 58 & 36 & 17 & gazetteer \\
\hline & Turdey & 53 & 22 & 38 & 00 & gazetteer \\
\hline & Lamskoe & 52 & 57 & 38 & 02 & gazetteer \\
\hline & Bol. Ogarevo & 53 & 33 & 37 & 43 & gazetteer \\
\hline
\end{tabular}

\section{Blasts Recorded}

Table 7 lists the blasts recorded in August and September, 1995, by date, mine location, blast size, recording station, distance and instrument type. Total charge sizes range from about 10 tons to 935 tons; source-receiver distances range from $60 \mathrm{~km}$ to $500 \mathrm{~km}$. The column labelled, "other information available" indicates the availability of information related to the details of the blasting deployment, such as the timing of individual charges in the ripple-fired blast, maps of the blocks detonated, and videotapes of the blasts. Detailed charge-time data are given in Appendix 3.

\section{Sample Seismograms}

Seismograms of all recorded blasts are given in Appendix 5. An example of seismograms recorded on the REFTEK at Svoboda for a blast from the Mikhaylovsky mine is shown in Figure 16, and an example of a broadband recording of a blast from Lebedinsky mine is shown in Figure 17.

\section{Magnitude Determinations}

Magnitudes of the blasts from the Kursk mines were determined at the seismic station Mykhnevo (MHV) using the formula: 
Table 7. List of blasts from the Kursk mining region recorded during August-September, 1995

\begin{tabular}{|c|c|c|c|c|c|c|c|c|c|c|c|}
\hline date & $\begin{array}{r}\text { Julian } \\
\text { day }\end{array}$ & $\begin{array}{r}\text { time } \\
(\mathrm{GMT}) \\
\end{array}$ & \begin{tabular}{|l} 
source \\
location
\end{tabular} & charge (t) & $\begin{array}{c}\text { magnitude } \\
\text { ML }\end{array}$ & $\begin{array}{l}\text { recording } \\
\text { station }\end{array}$ & $\begin{array}{c}\text { distance } \\
(\mathbf{k m})\end{array}$ & $\begin{array}{l}\text { data a } \\
\text { paper rec. }\end{array}$ & $\begin{array}{l}\text { ISGS } \\
\text { disk rec. }\end{array}$ & \begin{tabular}{|l} 
recording \\
instrument
\end{tabular} & $\begin{array}{l}\text { other info. } \\
\text { available }\end{array}$ \\
\hline 4-Aug-95 & 216 & $10: 08$ & Stoilensky & 299.4 & 2.6 & Mikhnevo & -500 & $\sqrt{ }$ & $\sqrt{ }$ & REFTEK & firing pattern, block map \\
\hline 10-Aug-95 & 222 & $8: 15$ & Lebedinsky & 424.2 & 3.4 & Mikhnevo & $\sim 500$ & & & broadband & firing pattern, block map \\
\hline 18-Aug-95 & 230 & 9:57 & Stoilensky & 195.6 & 2.2 & Svoboda & $\sim 130$ & $\sqrt{ }$ & $\sqrt{ }$ & REFTEK & firing pattern, block map \\
\hline \multirow[t]{5}{*}{ 24-Aug-95 } & \multirow[t]{5}{*}{236} & \multirow[t]{5}{*}{ 8:10 } & \multirow[t]{5}{*}{ Lebedinsky } & \multirow[t]{5}{*}{834.6} & \multirow[t]{5}{*}{3.2} & Svoboda & $\sim 130$ & $\sqrt{ }$ & $\sqrt{ }$ & REFTEK & \multirow[t]{5}{*}{ firing pattern } \\
\hline & & & & & & Elets & -150 & $\sqrt{ }$ & & TEAC & \\
\hline & & & & & & Mykhnevo & -500 & $\sqrt{ }$ & & broadband & \\
\hline & & & & & & $\operatorname{Tim}$ & -65 & & $\sqrt{ }$ & TEAC & \\
\hline & & & & & & Turdey & $\sim 240$ & & $\sqrt{ }$ & TEAC & \\
\hline 26-Aug-95 & 238 & $\sim 20: 00$ & Gubkin & 36.68 & 2.0 & Svoboda & -120 & $\sqrt{ }$ & $\sqrt{ }$ & REFTEK & firing pattern \\
\hline \multirow[t]{2}{*}{ 1-Sep-95 } & \multirow[t]{2}{*}{244} & \multirow[t]{2}{*}{$\sim 8: 00$} & \multirow[t]{2}{*}{ Mikhaylovsky } & \multirow[t]{2}{*}{270} & \multirow[t]{2}{*}{2.6} & Svoboda & -60 & $\sqrt{ }$ & $\sqrt{ }$ & REFTEK & \\
\hline & & & & & & Tim & -130 & $\sqrt{ }$ & & TEAC & \\
\hline \multirow[t]{2}{*}{ 1-Sep-95 } & \multirow[t]{2}{*}{244} & \multirow[t]{2}{*}{$10: 00$} & \multirow[t]{2}{*}{ Stoilensky } & \multirow[t]{2}{*}{221.3} & \multirow[t]{2}{*}{2.5} & Svoboda & $\sim 130$ & $\sqrt{ }$ & $\sqrt{ }$ & REFTEK & \multirow{2}{*}{$\begin{array}{l}\text { video; block map; } \\
\text { block timing }\end{array}$} \\
\hline & & & & & & Tim & -65 & $\sqrt{ }$ & & TEAC & \\
\hline 2-Sep-95 & 245 & $20: 00$ & Gubkin & $10 ?$ & & Svoboda & $\sim 120$ & $\sqrt{ }$ & $\sqrt{ }$ & REFTEK & \\
\hline \multirow[t]{4}{*}{ 7-Sep-95 } & \multirow[t]{4}{*}{250} & \multirow[t]{4}{*}{$8: 31$} & \multirow{4}{*}{ Lebedinsky } & \multirow[t]{4}{*}{633.7} & \multirow[t]{4}{*}{3.0} & Svoboda & -130 & $\sqrt{ }$ & $\sqrt{ }$ & REFTEK & \multirow{4}{*}{$\begin{array}{l}\text { video; } \\
\text { block map; } \\
\text { block timing }\end{array}$} \\
\hline & & & & & & Tim & -65 & $\sqrt{ }$ & & TEAC & \\
\hline & & & & & & Bol. Ogarevo & -270 & $\sqrt{ }$ & & TEAC & \\
\hline & & & & & & Lamskoe & $\sim 180$ & $\sqrt{ }$ & $\sqrt{ }$ & TEAC & \\
\hline \multirow[t]{2}{*}{ 8-Sep-95 } & \multirow[t]{2}{*}{251} & \multirow[t]{2}{*}{$8: 00$} & \multirow[t]{2}{*}{ Mikhaylovsky } & \multirow[t]{2}{*}{320} & 2.8 & Mikhnevo & $\sim 340$ & $\sqrt{ }$ & $\sqrt{ }$ & broadband & \\
\hline & & & & & & Svoboda & -60 & $\sqrt{ }$ & $\sqrt{ }$ & REFTEK & clipped; 2 events \\
\hline $10-$ Sep-95 & 253 & $-8: 00$ & Lebedinsky & N/A & & Mikhnevo & $\sim 500$ & $\sqrt{ }$ & & REFTEK & \\
\hline
\end{tabular}




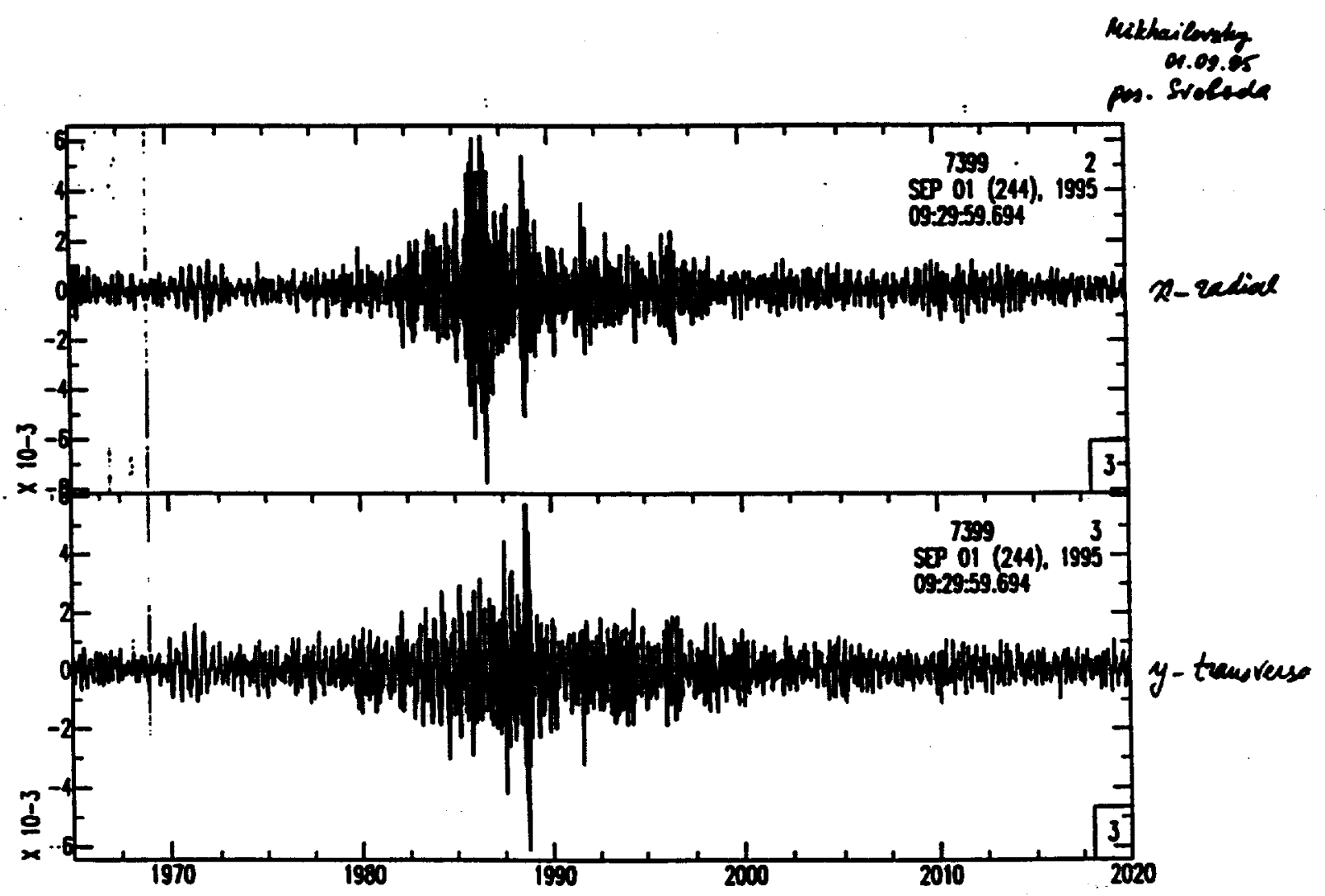

Figure 16. Examples of seismograms recorded on the REFTEK recorder deployed at Svoboda. Shown are the radial and transverse components of records of the blast of September 1, 1995, detonated at the Mikhaylovsky mine. The blast was 270 tons total charge, recorded at a distance of $60 \mathrm{~km}$. A magnitude $M_{L}=2.6$ was calculated for this blast. 


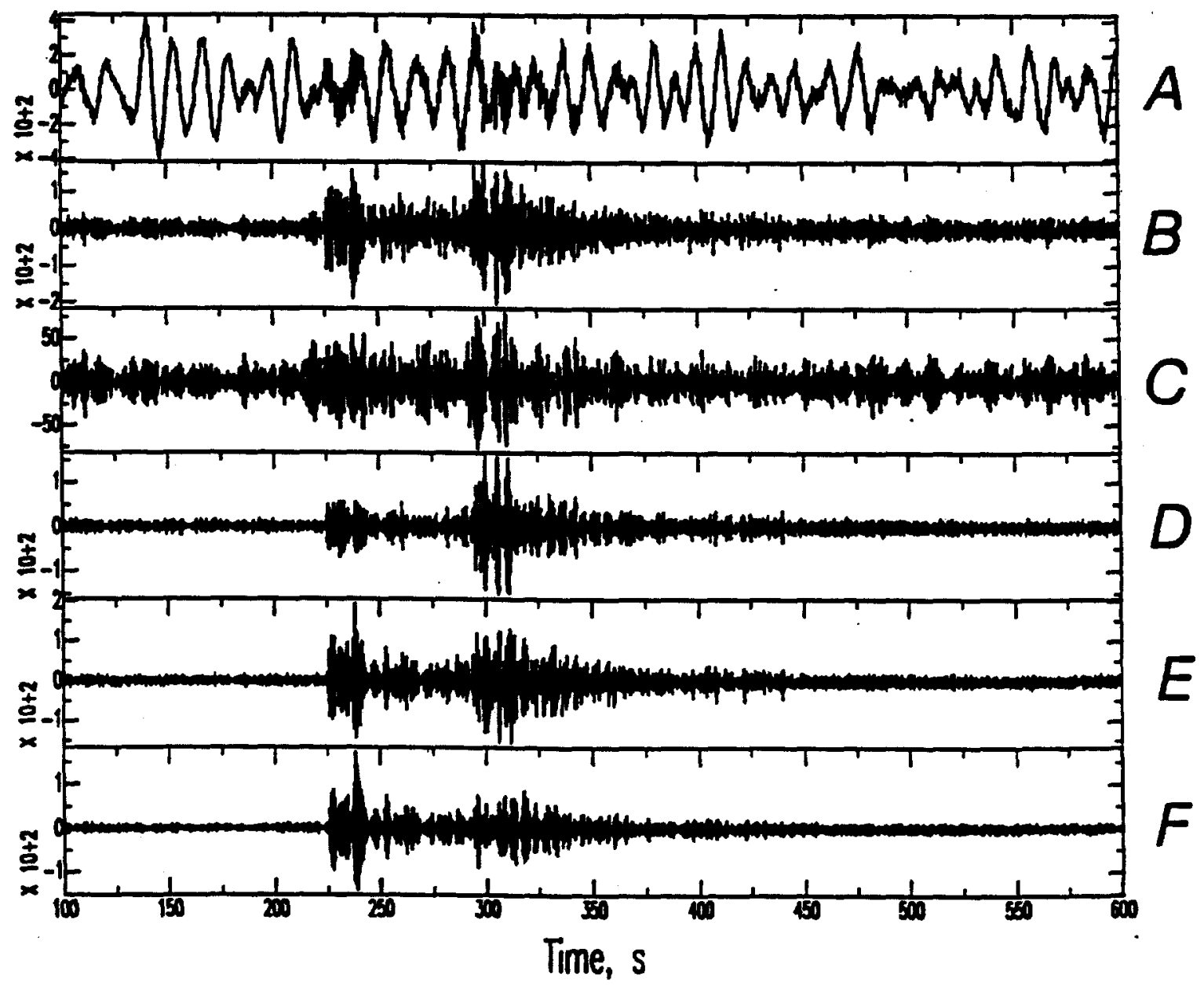

Figure 17. Example of the raw and filtered trace of the broadband recording of the blast of September 8, 1995, recorded at Mykhnevo (MHV), $340 \mathrm{~km}$ to the North. Trace $A$ is unfiltered. Traces $B-F$ are band-passed as follows: $B, 0.7 \mathrm{~Hz}$ to nyquist; $C, 0.7$ $-1.4 \mathrm{~Hz} ; D, 1-2 \mathrm{~Hz} ; E, 1.4-2.8 \mathrm{~Hz} ; F, 2 \mathrm{~Hz}$ to nyquist. 


$$
M_{P V}=\log \left(A_{\max } / T\right)+\sigma(d, h)
$$

where $A_{\max }$ is the maximum amplitude of the p-wave on the vertical component of the short-period seismogram, $T$ is the visible period, $d$ is the epicentral distance, $h$ is the depth of the event (zero, for mining blasts), and $\sigma$ is $\mathrm{n}$ empirical calibration function for the station (Instruktsiya, 1982). The station was calibrated using earthquakes from the Caucasus region, to the south of Kursk (Solov'ev and others, 19-). In practice, magnitudes were graphically picked from a nomogram, which is given in Appendix 6.

In addition, the NORSAR regional bulletins were reviewed to determine if any of the Lebedinsky blasts from 1992-1995 were located events by the Scandinavian seismic arrays. Of the more than 100 blasts listed in Appendix 1, only one appears in the regional bulletins. This blast, which occurred on May 22, 1992 and was 1221.7 tons total charge, was detected by three arrays (NORESS, ARCESS and FINESS), and located approximately $100 \mathrm{~km}$ SW of the mine. The NORSAR magnitude, $m_{b}=2.9$, compares with a Russian-determined $M_{L}=3.6$, calculated from the records at Mykhnevo by the method described above.

\section{Spectral Analysis}

The visible effects of large, surface mining blasts (cratering, deformation of quarry's sides resulting from rock mass drop, gas dust cloud), as well as their controlled periodicity, can assist in their detection and discrimination from other types of seismic events. However, in most cases, this information will not be available, and a detailed analysis of the seismic signal may allow the determination of distinctive indications of mass industrial explosions. In the case of ripple-fired explosions, the high frequency seismic trace has prominent spectral modulation believed to indicate ripple-firing (Baumgardt, Ziegler, 1988). Spectral modulation parameters are determined by the precise time periods between the explosions of groups of boreholes. For a more detailed description of this effect, see, for example, Hedlin and others (1990).

Spectra and sonograms were calculated for two industrial chemical explosions with yields of 834 and 634 metric tons, conducted at Lebedinsky quarry in 1995, and recorded at distances $150 \mathrm{~km}$ and $180 \mathrm{~km}$, respectively, Figures 18 and 19 show the seismograms of these blasts, along with the corresponding spectra. Spectral modulation is seen distinctly in the accompanying sonograms. Additional evidence that these explosions were ripple-fired comes from a calculation of the cepstrum of the seismogram. If the blasting is conducted with the constant delay times between charges, the consequent multiplicity of sources results in cepstral peaks (Hedlin and others, op cit.). This work is incomplete for the blasts recorded at Kursk in 1995.

\section{Discussion}

In this study, we have chararcterized the large mining blasts at Kursk, based both a review of blasting at mines in the Gubkin region over the past 5 years and on a sample of seismically-recorded blasts from August-September, 1995. This work has included compiling information on the spatial and temporal distribution of charges for both 
FINAL REPORT--USGS/UC-LLL MOA B291532
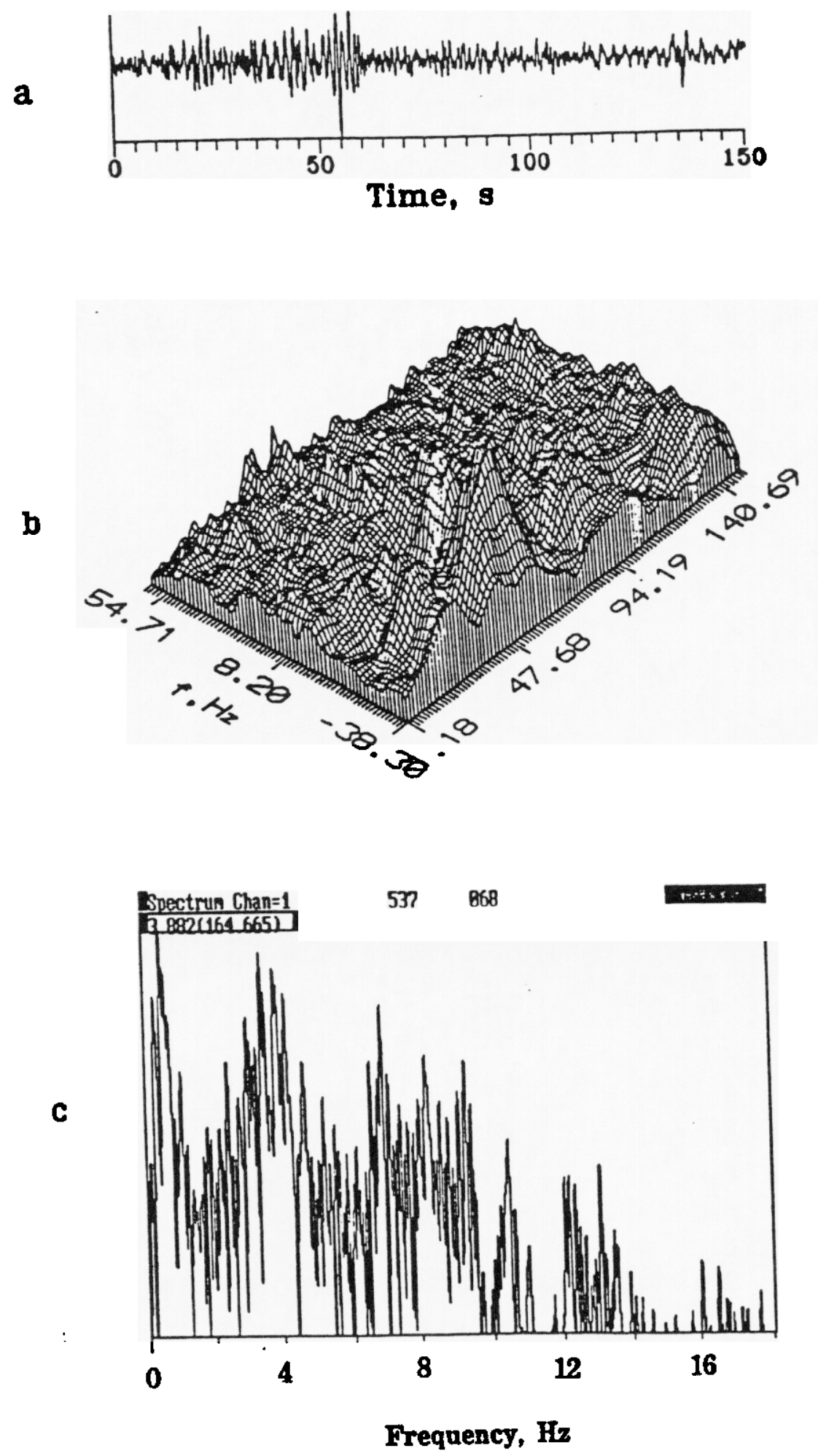

Figure 18. Seismogram, sonogram and log of the spectrum of the blast of August 24, 1995, at Lebedinsky mine (834 tons). 
FINAL REPORT--USGS/UC-LLL MOA B291532
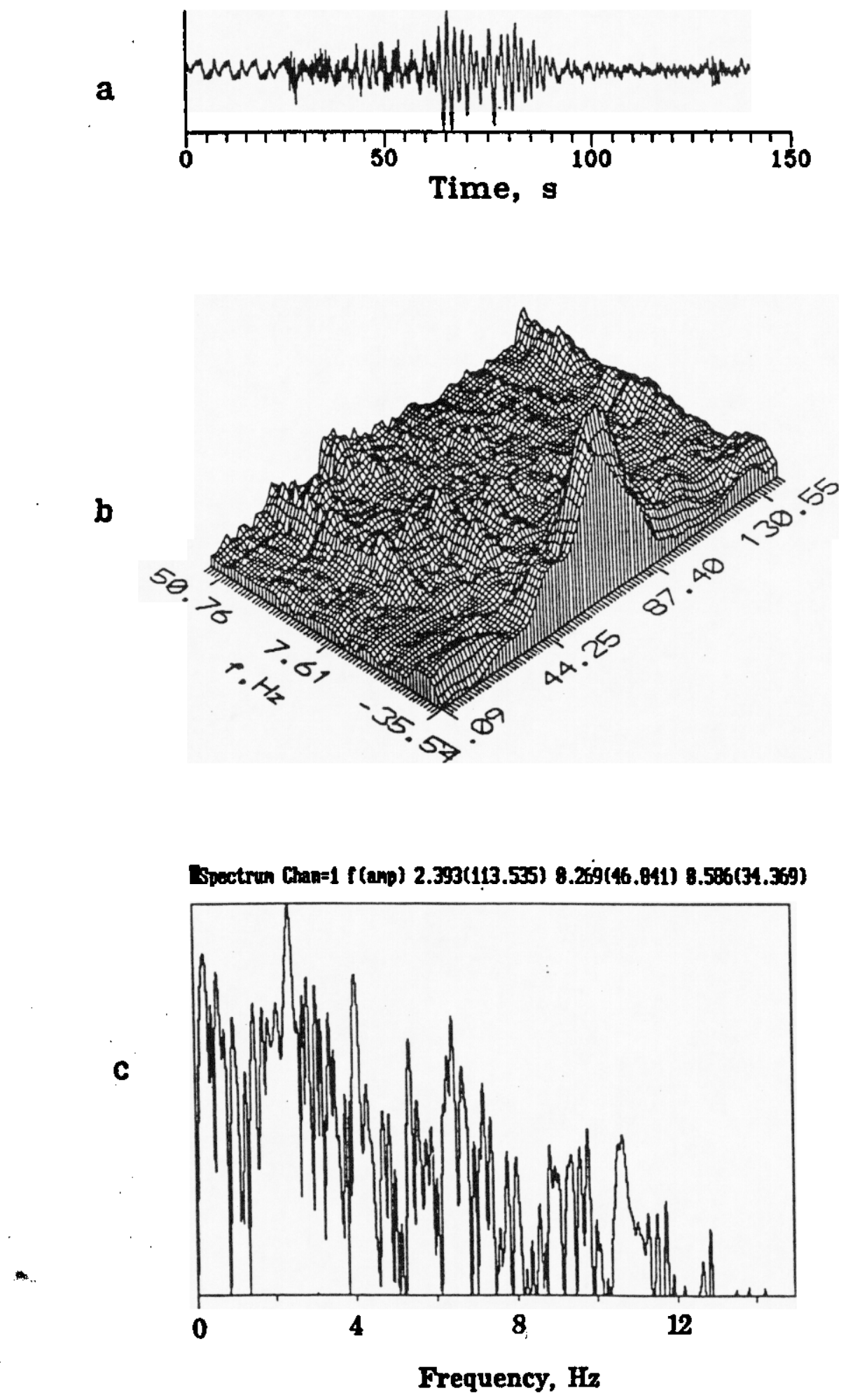

Figure 19. Seismogram, sonogram and log of the spectrum of the blast of Septebmer 7, 1995, at Lebedinsky mine (634 tons). 
surface and underground blasts, videotaping of individual blasts, compiling data on explosives, and providing information on the context of these blasts with respect to both Russian, Soviet and U.S. blasting. Twelve blasts from August-September, 1995, were recorded on two permanent and six portable seismic stations at distances ranging from 60 to $500 \mathrm{~km}$ from one of four blasting sites.

Based on this work, several features of the blasts at Kursk should be emphasized:

1) Blasting at Kursk is clearly diminished over the levels of only a few years ago; both the total number of blasts has decreased, as well as the average total charge per blast.

2) Blasting practice in the surface mines at Kursk has changed, such that the predominant mode is true ripple firing, in which many delays are used along the rock face (which we have called, "reduced-shaking mode". Nevertheless, this ripple-firing practice does not match that used in major mines in the U.S. in that entire rows of holes are still blasted at once, detonating as much as $\mathbf{1 0}$ tons of explosive in a single delay.

3) Data on a limited number of blasts in the underground mines at Kursk indicates that relatively large charge-per-delay are used; over 4 tons in several cases. These amounts are essentially the same as those used in the surface mines.

4) Local magnitudes, $M_{L}$, determined at near-regional distances $(300-500 \mathrm{~km})$, range from about 2.5 to 3.5, for blasts with total charges of about 200 to 850 tons. Figure 20 shows these magnitudes compared with explosions from the Soviet program of peaceful nuclear explosions and with chemical explosions in Russia and the former Soviet Union that were detonated for non-mining purposes. Note that these magnitudes correlate well with total charge, a feature not observed in ripple-fired miing blasts in other studies. This may reflect particular features of the blasting practice used at Kursk, or it may be related to the method of magnitude determination used.

5) Of over 100 blasts detonated in the years 1992-1995, only one of these blasts was located by the seismic arrays in Scandinavia. This blast, from 1992, had a teleseismic magnitude, $m_{b}$ of 2.9 , and a regional magnitude, $M_{L}$, of 3.6. While this is only one point for comparison, it suggests that there may be a significant discrepancy between the teleseismic magnitude, $m_{b,}$, and a regional magnitude, $M_{L,}$, as determined at the station MHV. It also suggests that most Kursk mining blasts will have teleseismic magnitudes less than 3.0, and may not be well recorded by the proposed International Monitoring System.

6) The large mining blasts from the surface mines at Gubkin show evidence of spectral scalloping, typical of ripple-fired mining blasts. This feature may aid in discriminating them from earthquakes and other seismic sources. 


\section{Magnitudes of Soviet Nuclear and Chemical Explosions}
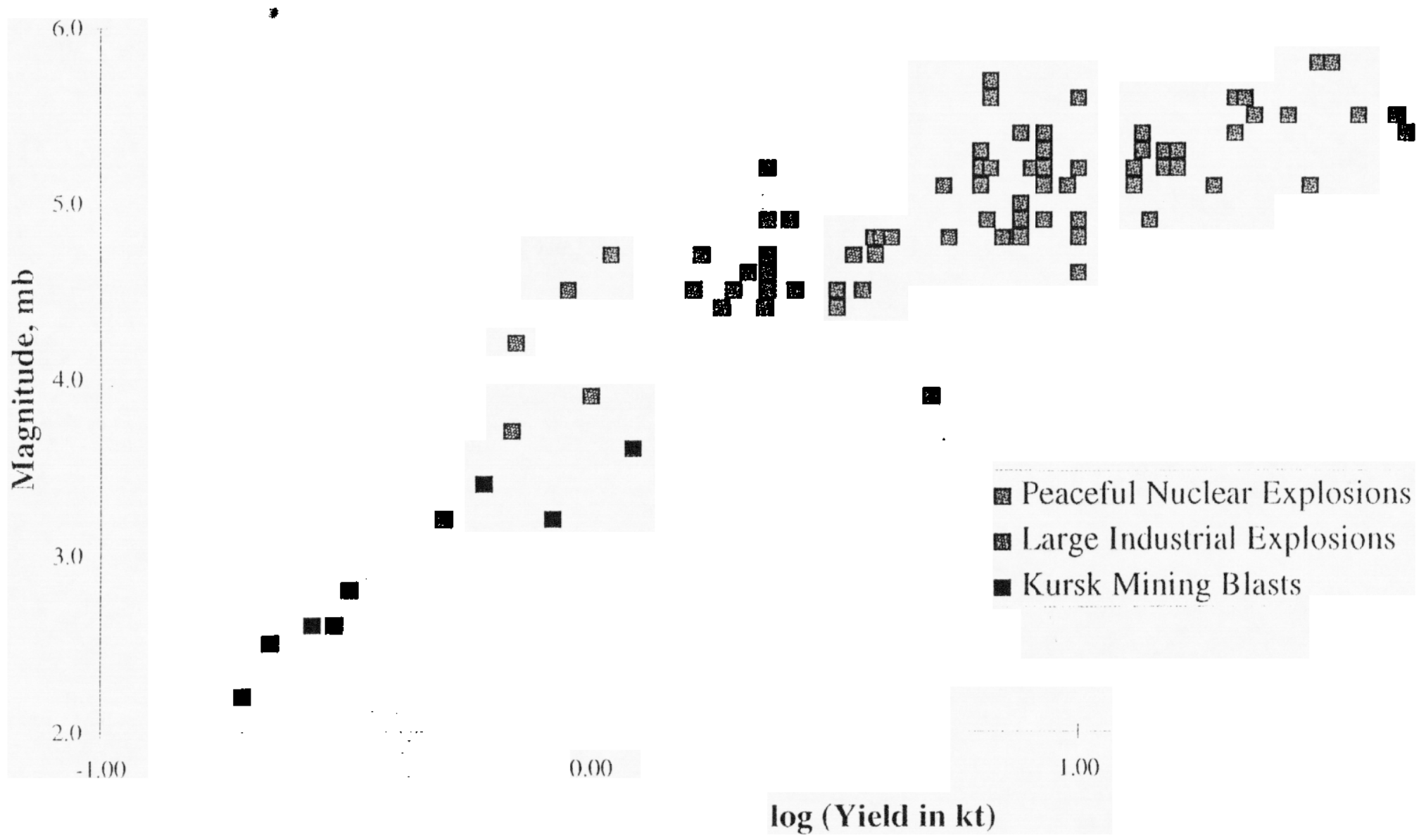

Figure 20. Comparison of the magnitudes of Soviet and Russian explosions: Peaceful nuclear explosions are shown in red; large chemical explosions for military and civilian purposes (but not mining) are shown in green; and the Kursk mining blasts are shown in blue. Note that the magnitudes of the Kursk blasts are not $m_{b}$; see text for details. 


\section{Acknowledgements}

Assistance in this work was provided by Leonid Pernik and Vadim Spungin of the Institute of Dynamics of Geospheres, and by John Unger and Jim Luetgert of the U.S. Geological Survey. Information derived from the seismic arrays in Scandinavia were provided by Frode Ringdahl of NORSAR, to whom we give many thanks. The digital seismic data from this study have been placed in an archive of the Lawrence Livermore Laboratory, and are available for research. For additional information, please contact the authors. 


\section{References}

Adushkin V., and A. Spivak, Geologic Characterization and Mechanics of Underground Nuclear Explosions, Defense Nuclear Agency. Alexandria, VA. U.S.A. 1994. 793 pp.

Adushkin, V.V., A.A. Spivak and W. Leith, 1996, Large-Scale Industrial Blasts And Ctbt Monitoring Problems, preprint of the Russian Academy of Sciences, Institute of Dynamics of Geospheres, 19pp.

Alexandrov, E.A., 1973, The Precambrian banded-iron formations of the Soviet Union, Economic Geology, v.68, p.1035-1062.

Baumgardt D., Ziegler K. (1988) Spectral evidence for source multiplicity in explosions: Application to regional discrimination of earthquakes and explosions. Bull.Seism.Soc. Am. Vol. 78, pp.1773-1795.

Cochran T., Arkin., Norris., Sands J. (1992) Soviet Nuclear Weapons, Moscow. "IzdAT". $460 \mathrm{pp}$. (in Russian).

Hedlin M., Minster J., Orcutt J. (1990) An automatic means to dscriminate between earthquakes and quarry blasts, Bull.Seim.Soc.Am., v. 80, No. 6, pp.2143-2160.

Identification mining blasts conducted in Australia: Study of spectral characteristics. Experts report at the Conference in Geneva, Switzerland. June 1995. 14 pp.

Instruktsiya o Poryadke Proizvodstva i Obrabotki Nablyudeniy na Seysmicheskikh Stantsiyakh Edinoy Sistemy Seysmicheskikh Nablyudenuy SSSR, 1982 (Moscow, 272pp.)

Laznika, P., 1993. Precambrian Empirical Metallogeny, v. 2, part a.

Leith, W. and L. Bruk, 1995a, A review of blasting activity in the former Soviet Union, in Proceedings, Symposium on the non-Proliferation Experiment, U.S. Department of Energy, p. 2-36 - 2-44.

Leith, W. and L. Bruk, 1995b, Blasting in the Magadan Oblast', Russia, 1989-1992, Technical Report No. 3 on AC94-1A-3003, U.S. Arms Control and Disarmament Agency, $10 \mathrm{pp}$.

Murphy J. Seismic source functions and magnitude determinations for underground nuclear detonations, Bull.Seism.Soc.Am., 1977, vol. 67, pp.135-158.

Murphy J. Types of Seismic Events and Their Source Discriptions, in Monitoring a Comprehensive Test Ban Treaty, Kluwer Academic Publishers, Netherlands, 1995, pp.225-245.

(continues) 
Murphy J., Rimer N., Stevens J. Comment on "Seismic decoupling with chemical and nuclear explosions on salt" by L.Glenn and P.Goldstein. J.Geophys.Res., 1996, vol.101, pp.845-850.

NORSAR Scientific Report No. 2-94/95, Kjeller, May 1995, pp.110.

Peaceful uses of underground nuclear explosions. In Nuclear explosions in USSR (1991). Vol.4. Editor Mikhailov V. Moscow, "Minatom". 166 pp.(in Russian).

Richards, P., D.A. Anderson and D.W. Simpson, 1992, A survey of blasting Activity in the United States, Bull. Seis. Soc. Am v.82, n.3, p.1416-1433.

Seismic verification of nuclear testing treaties (1992). Editors: Adushkin V., Spivak A. Moscow: "Mir", 216 pp. (in Russian).

Solov'ev, O., A. Bagramyan, T. Yanovskaya and M. Petrosya, 1983, Investigation of the amplitude field of seismic waves of the nearest Caucasus earthquakes.

Soviet-American works for seismic monitoring of a nuclear explosions (1991). Editors: Nersesov I., Sidorin A. Moscow: "Nauka", 144 pp (in Russian).

Spivak A. (1973) Compression waves in solid medium due to explosion in aerial cavity. Physics of burn and explosion. No.2, pp.263-268 (in Russian).

Spivak A. (1995) Methods of evading detection by a nuclear explosion monitoring network under special condition. Monitoring a Comprehensive Test Ban Treaty. Kluwer Academic Publishers, Netherlands,, pp.295-308.

Spivak A., Tchernyshev A. (1996) Conception of regional seismic monitoring CTBT. Russia's Federal System of Seismological Networks and Earthquake Prediction. No.4.

Vanecek, M., ed., 1994, Mineral Deposits of the World, Elsevier (Amsterdam). 


\section{Appendix I: Catalog of Mining Explosions at Lebedinsky GOK, 1992-1995 \\ [Explosives: granulotol, grammonit]}

\section{2}

\begin{tabular}{|c|c|c|c|c|}
\hline $\begin{array}{l}\text { Ref. } \\
\text { No. }\end{array}$ & $\begin{array}{l}\text { Date } \\
\text { da mo yr }\end{array}$ & $\begin{array}{l}\text { Time } \\
\text { Moscow) }\end{array}$ & $\begin{array}{l}\text { Total Charge } \\
\text { metric tons }\end{array}$ & \\
\hline 1 & 06.02 .92 & $12: 00$ & 871.7 & \\
\hline 2 & 21.02 .92 & $12: 00$ & 1248.1 & \\
\hline 3 & 05.03 .92 & $12: 00$ & 1110.0 & \\
\hline 4 & 19.02 .92 & $12: 00$ & 979.0 & \\
\hline 5 & 02.04 .92 & $12: 00$ & 1314.6 & \\
\hline 6 & 16.04 .92 & $12: 00$ & 996.6 & \\
\hline 7 & 30.04 .92 & $12: 00$ & 786.7 & \\
\hline 8 & 08.05 .92 & 9:00 & 290.6 & \\
\hline 9 & 14.05 .92 & N/A & 694.0 & $871.7 ?$ \\
\hline 10 & 22.05 .92 & $12: 00$ & 1221.7 & ${ }^{*} \mathrm{~m}_{b}=2.9$, NORSAR bulletin \\
\hline 11 & 11.06 .92 & $.13: 22$ & 1568.5 & \\
\hline 12 & 25.06 .92 & $12: 00$ & 1273.5 & - \\
\hline 13 & 09.07 .92 & $12: 00$ & 867.9 & \\
\hline 14 & 23.07 .92 & $13: 00$ & 660.5 & \\
\hline 15 & 11.08 .92 & $13: 30$ & 1436.7 & \\
\hline 16 & 25.08 .92 & $12: 03$ & 1299.6 & \\
\hline 17 & 17.09 .92 & $12: 32$ & 1187.6 & \\
\hline 18 & 08.10 .92 & $14: 52$ & 1126.1 & . \\
\hline 19 & 15.10 .92 & $12: 00$ & 792.4 & \\
\hline 20 & 30.10 .92 & $12: 02$ & 776.9 & \\
\hline 21 & 13.11 .92 & $12: 00$ & 558.3 & - \\
\hline 22 & 19.11 .92 & $12: 00$ & 671.8 . & \\
\hline 23 & 26.11 .92 & $12: 00$ & 356.7 & \\
\hline 24 & 10.12 .92 & $11: 58$ & 1475.8 & \\
\hline 25 & 18.12 .92 & $14: 20$ & 247.0 & \\
\hline 26 & 28.12 .92 & $12: 46$ & 1862.0 & \\
\hline
\end{tabular}




\section{3}

\begin{tabular}{|c|c|c|c|}
\hline $\begin{array}{l}\text { Ref. } \\
\text { No. }\end{array}$ & $\begin{array}{l}\text { Date } \\
\text { da mo yr }\end{array}$ & $\begin{array}{l}\text { Time } \\
\text { (Moscow) }\end{array}$ & $\begin{array}{l}\text { Total Charge } \\
\text { metric tons }\end{array}$ \\
\hline 1 & 14.01 .93 & $12: 00$ & 988.1 \\
\hline 2 & 21.01 .93 & $12: 00$ & 474.3 \\
\hline 3 & 04.02 .93 & $12: 00$ & 857.0 \\
\hline 4 & 18.02 .93 & $12: 00$ & 936.6 \\
\hline 5 & 04.03 .93 & 13:00 & 911.2 \\
\hline 6 & 25.03 .93 & $12: 30$ & 456.6 \\
\hline 7 & 01.04 .93 & $12: 00$ & 685.9 \\
\hline 8 & 08.04 .93 & $12: 00$ & 1082.2 \\
\hline 9 & 15.04 .93 & $12: 00$ & 534.1 \\
\hline 10 & 29.04 .93 & $12: 00$ & 407.1 \\
\hline 11 & 07.05 .93 & $12: 50$ & 434.3 \\
\hline 12 & 21.05 .93 & $12: 35$ & 1082.5 \\
\hline 13 & 24.05 .93 & $15: 20$ & 118.0 \\
\hline 14 & 04.06 .93 & $12: 00$ & 752.7 \\
\hline 15 & 15.06 .93 & $12: 30$ & 1177.2 \\
\hline 16 & 01.07 .93 & $12: 00$ & 1413.4 \\
\hline 17 & 15.07 .93 & $12: 00$ & 566.5 \\
\hline 18 & 22.07 .93 & $12: 00$ & 272.2 \\
\hline 19 & 29.07 .93 & $12: 30$ & 1058.3 \\
\hline 20 & 12.08 .93 & $15: 35$ & 1192.7 \\
\hline 21 & 09.09 .93 & $13: 00$ & 456.9 \\
\hline 22 & 16.09 .93 & $13: 00$ & 354.2 \\
\hline 23 & 23.09 .93 & $12: 00$ & 401.0 \\
\hline 24 & 30.09 .93 & $12: 00$ & 248.2 \\
\hline 25 & 07.10 .93 & $12: 05$ & 388.8 \\
\hline 26 & 14.10 .93 & $13: 15$ & 350.8 \\
\hline 27 & 21.10 .93 & $12: 00$ & 349.5 \\
\hline 28 & 28.10 .93 & $12: 00$ & 340.4 \\
\hline 29 & 04.11 .93 & $12: 02$ & 355.2 \\
\hline 30 & 18.11 .93 & $12: 10$ & 581.5 \\
\hline 31 & 25.11 .93 & $12: 00$ & 297.6 \\
\hline 32 & 02.12 .93 & $12: 19$ & 301.2 \\
\hline 33 & 16.12 .93 & $12: 25$ & 426.3 \\
\hline 34 & 30.12 .93 & $12: 12$ & 323.4 \\
\hline
\end{tabular}




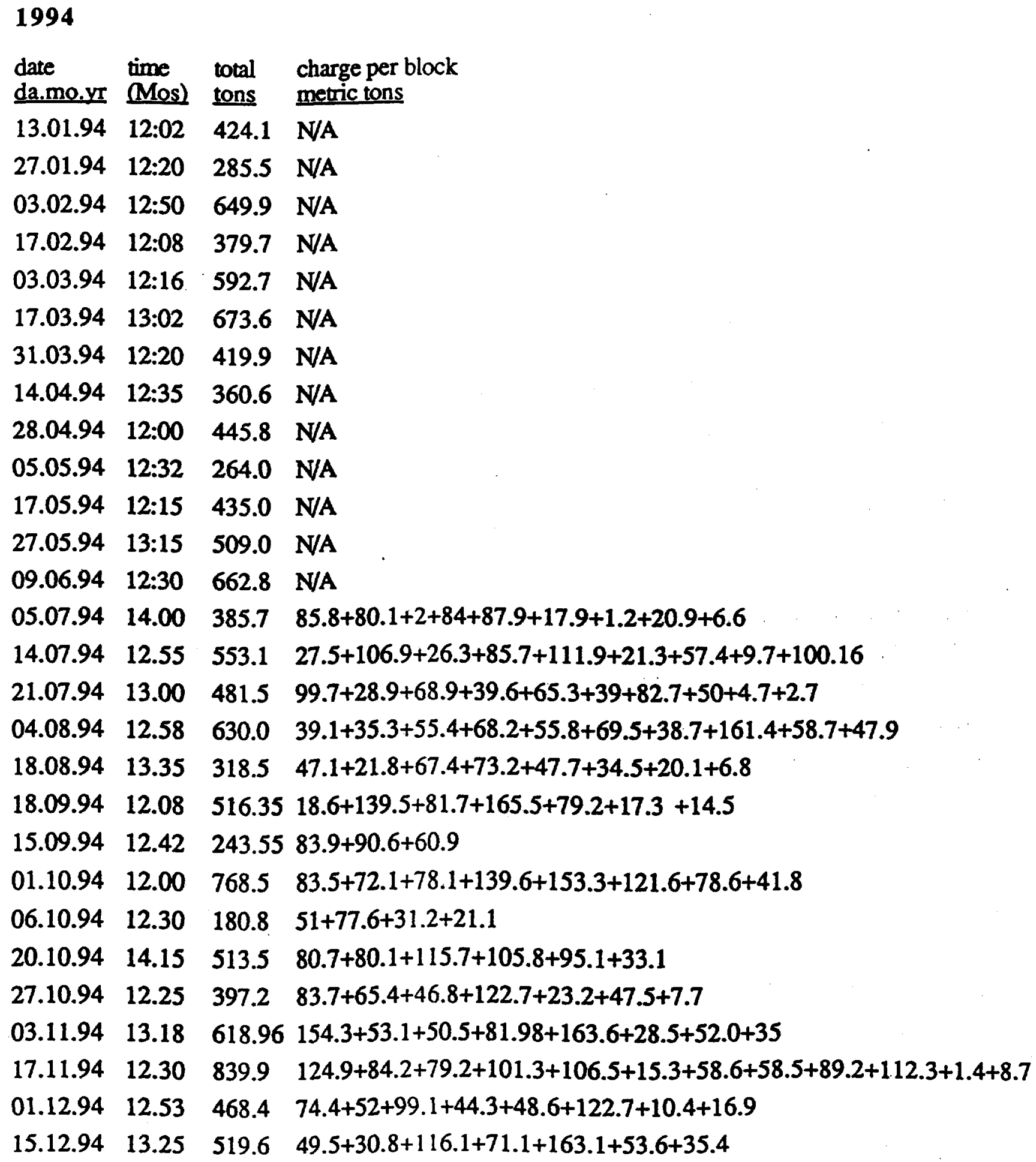


FINAL REPORT--USGS/UC-LLL MOA B291532

\author{
1995 \\ date time total charge per block \\ da.mo.yr (Mos) tons metric tons \\ $06.01 .95 \quad 12.05 \quad 663.2 \quad 56.2+92.6+81.5+112.8+90.4+213.4+16.3$ \\ $19.01 .95 \quad 12.35 \quad 1109.5 \quad 135.6+140.0+183+121.9+159.3+20.4+98.4+87.6+46.3+116.7$ \\ $02.02 .95 \quad 12.32718 .46 \quad 45+109.2+89.5+88.2+83+32.8+92.4+125+23.7+23.7$ \\ $\begin{array}{llll}16.02 .95 & 12.03 & 882.2 & 34.6+43.5+115.2+72.6+23+153.4+53.3\end{array}$ \\ 02.03.95 $13.10 \quad 1021.7$ \\ $132.2+77.4+29.3+41.2+109.4+62+92.4+34.4+4.8+12.5+16+8.4+5.8+0$. \\ 24.03.95 $12.18 \quad 1455.1$ \\ $168.7+138.6+44.4+34.3+160.7+191.9+53.5++300+193.9+90.5+222.7+30.4$ \\ $06.04 .95 \quad 12.10 \quad 291.4 \quad 77.7+42.8+79.4+62.1+48.6+72.3+23.7+152.3+35.7$ \\ $\begin{array}{llll}20.04 .95 & 12.00 & 560.4 & 87.1+59.4+96.3+1.9+121.7+114.2+79.6\end{array}$ \\ $27.04 .95 \quad 12.22 \quad 101.2 \quad 67.6+33+0.6$ \\ $06.05 .95 \quad 12.02 \quad 729.4 \quad 174 .+46+72.6+113.3+44.7+121.1+157.6$ \\ $\begin{array}{lll}18.05 .95 & 12.40 \quad 868.85\end{array}$ \\ $114.4+107.7+27.1+31.7+55.8+27.6+126.6+176.3+85.8+113.9+1.3$ \\ $08.06 .95 \quad 12.19 \quad 460.6 \quad 125.8+76+305.4+125.7+8+98.4$ \\ $22.06 .95 \quad 12.15 \quad 625.7 \quad 89.2+82.2+102.7+127.9+124.6+16.8+30.2+52.4$ \\ $29.06 .95 \quad 12.10 \quad 430.5 \quad 22.5+88+186.9+36.5+48.2$ \\ $13.07 .95 \quad 12.03 \quad 924.8 \quad 59.4+152.9+32+141.2+47.8+164.9+93.3+181.6+38.1+12+4+1.5$ \\ $27.07 .95 \quad 12.35 \quad 717.2 \quad 77.6+130+14.4+6.6+86.2+66.4+80+49.2+76.5+130.5$ \\ $10.08 .95 \quad 12.15 \quad 603.4 \quad 139.8+78.5+98+109.7+67.7+20.2+44.8+2.3+40.6+1.6$ \\ $24.08 .95 \quad 12.10 \quad 834.6$ \\ $135.2+18.9+41.5+62.6+92.8+60.7+171.8+65.8+17.4+50+99+13.9+1.7$ \\ $\begin{array}{llll}07.09 .95 & 12.34 & 633.7 & 73.36+68.36+196.77+48+117.53+150\end{array}$ \\ $21.09 .95 \quad 12.05 \quad 638.6 \quad 138.16+162.72+95.48+10.6+161+70.66$ \\ $28.09 .95 \quad 12.01 \quad 235.2 \quad 77.87+91.16+61.4+0.38+2.54+1.8$
}




\section{Appendix 2: List of Explosives}

Commonly Used in Russia and the former Soviet Union

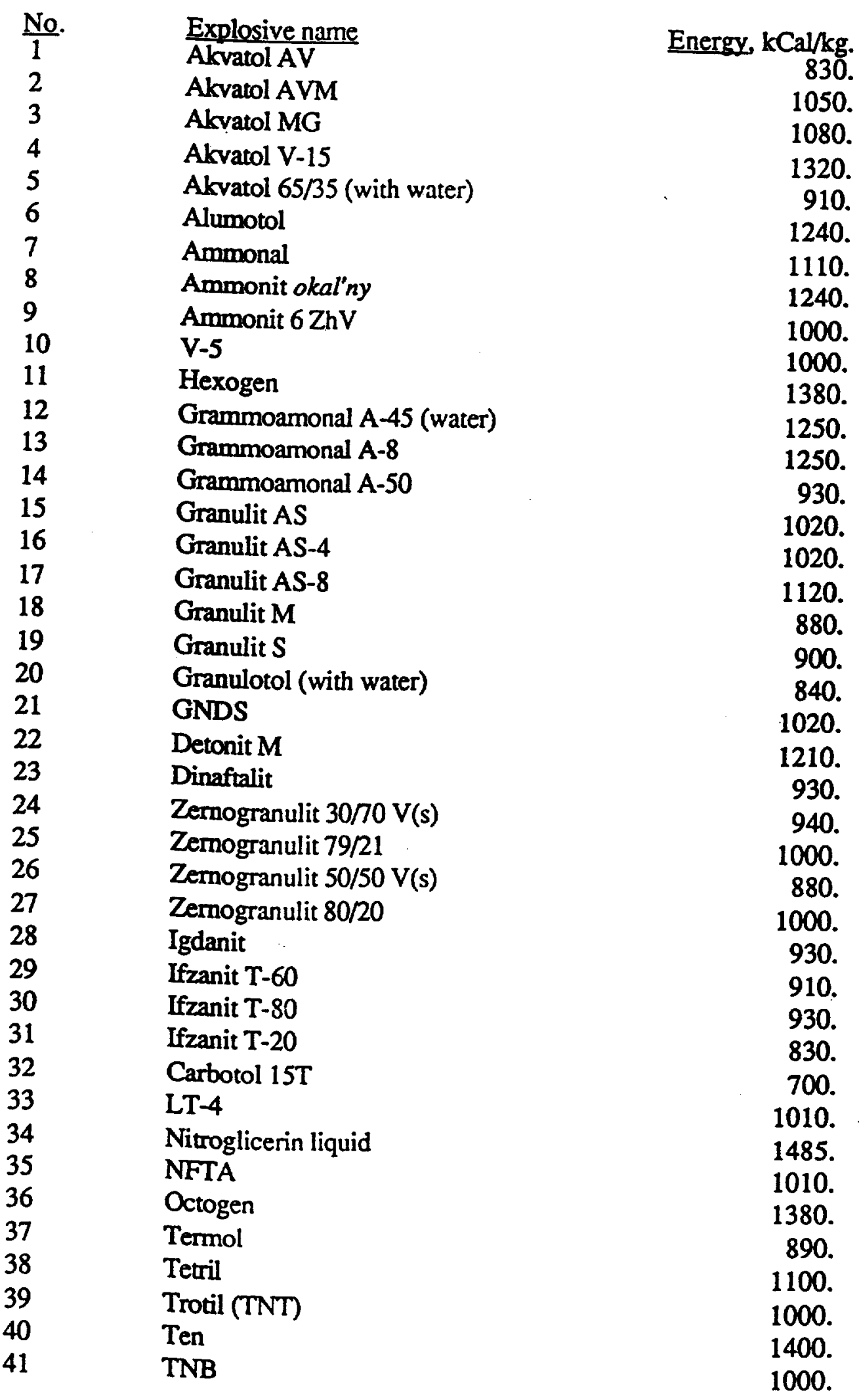


Appendix 3: Sketch maps of the locations of charge blocks for blasts at the Lebedinsky and Stoylensky open pit mines.
A.3.1-
August 4, 1995, Stoylensky mine, 299.4 tons

A.3.2- $\quad$ August 10, 1995, Lebedinsky mine, 424.2 tons

A.3.3-

August 18, 1995, Stoylensky mine, 195.6 tons

A.3.4- September 1, 1995, Stoylensky mine, 221.3 tons

A.3.5- September 1, 1995, Stoylensky mine, 221.3 tons

A.3.6- September 7, 1995, Lebedinsky mine, 633.7 tons 


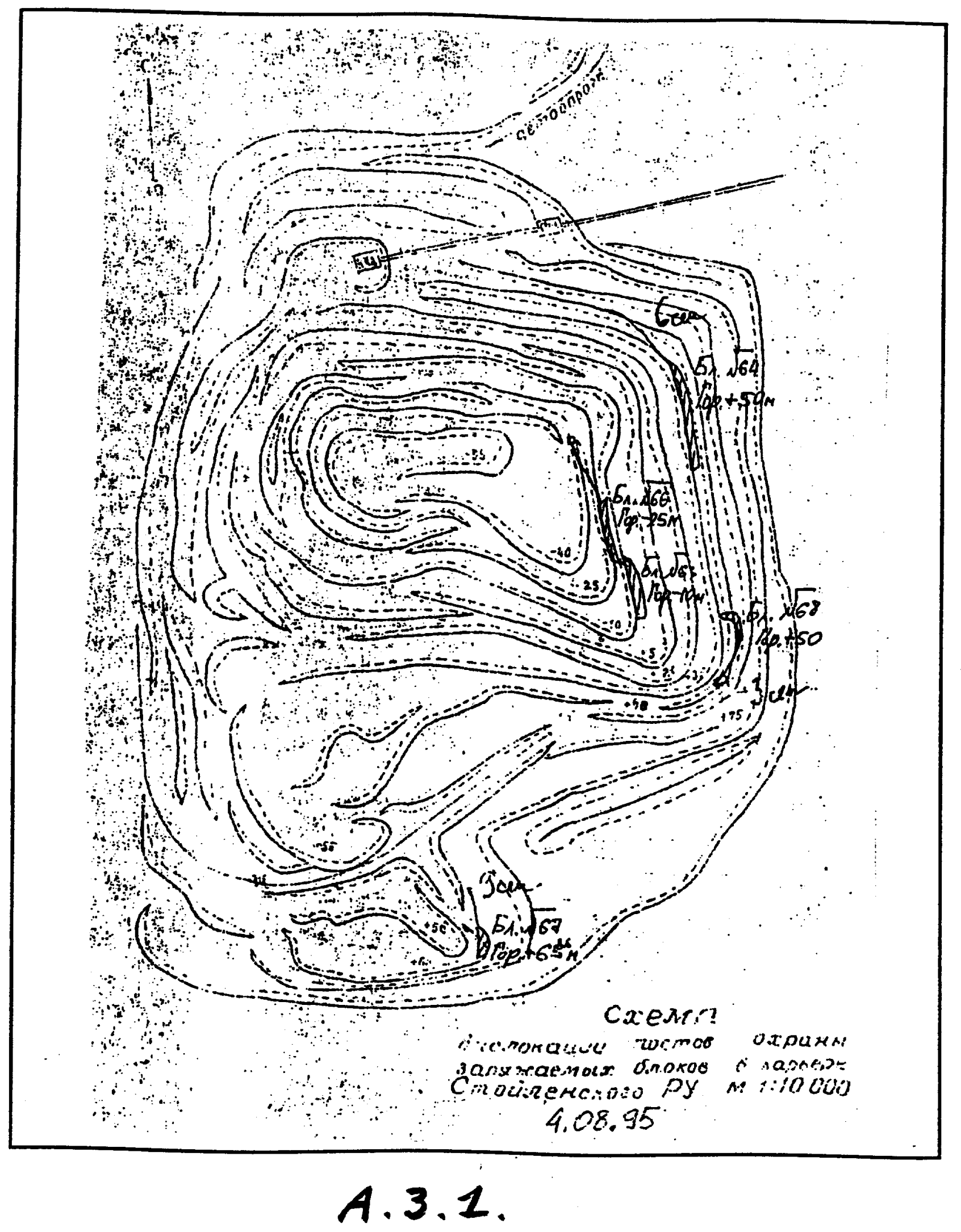




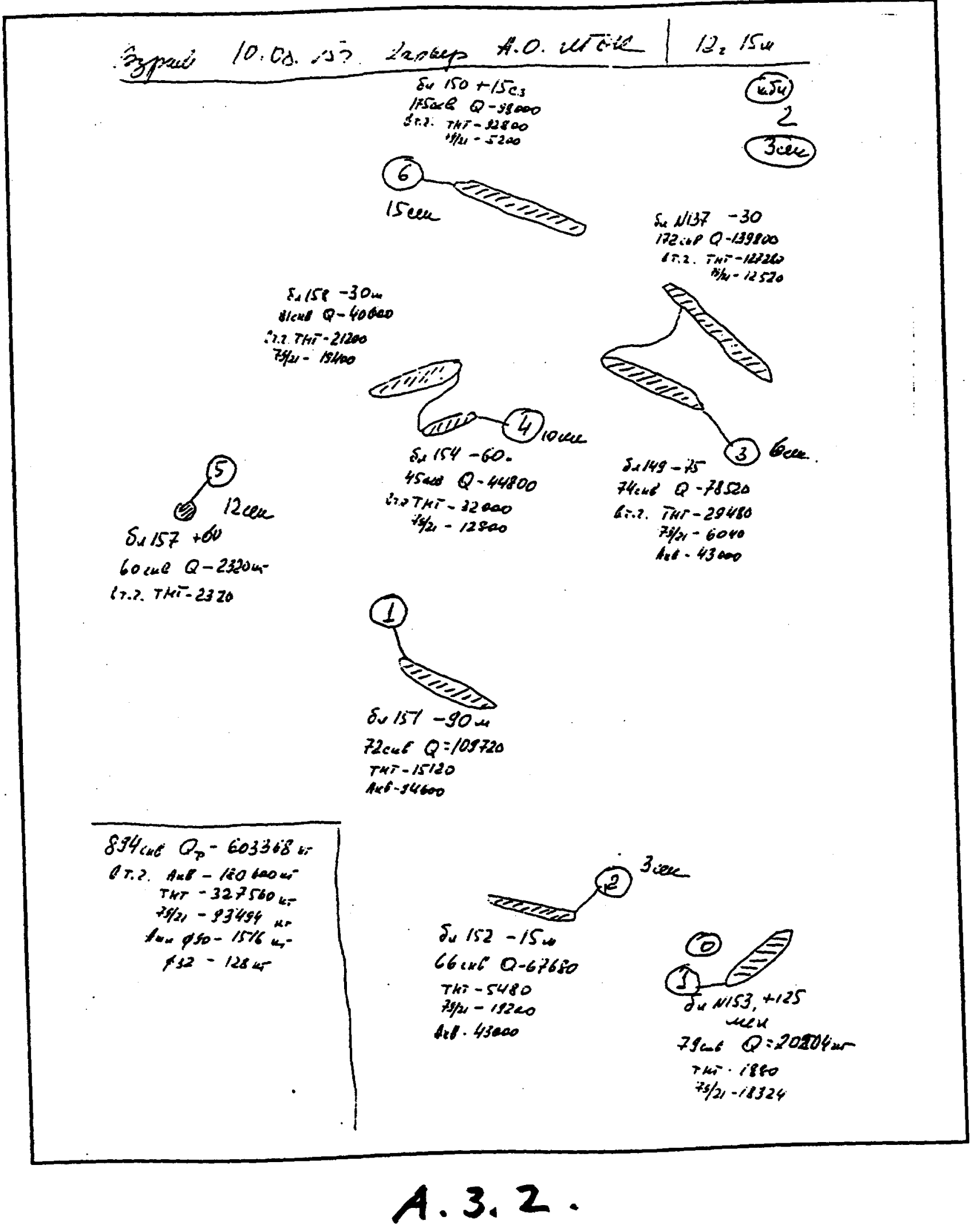




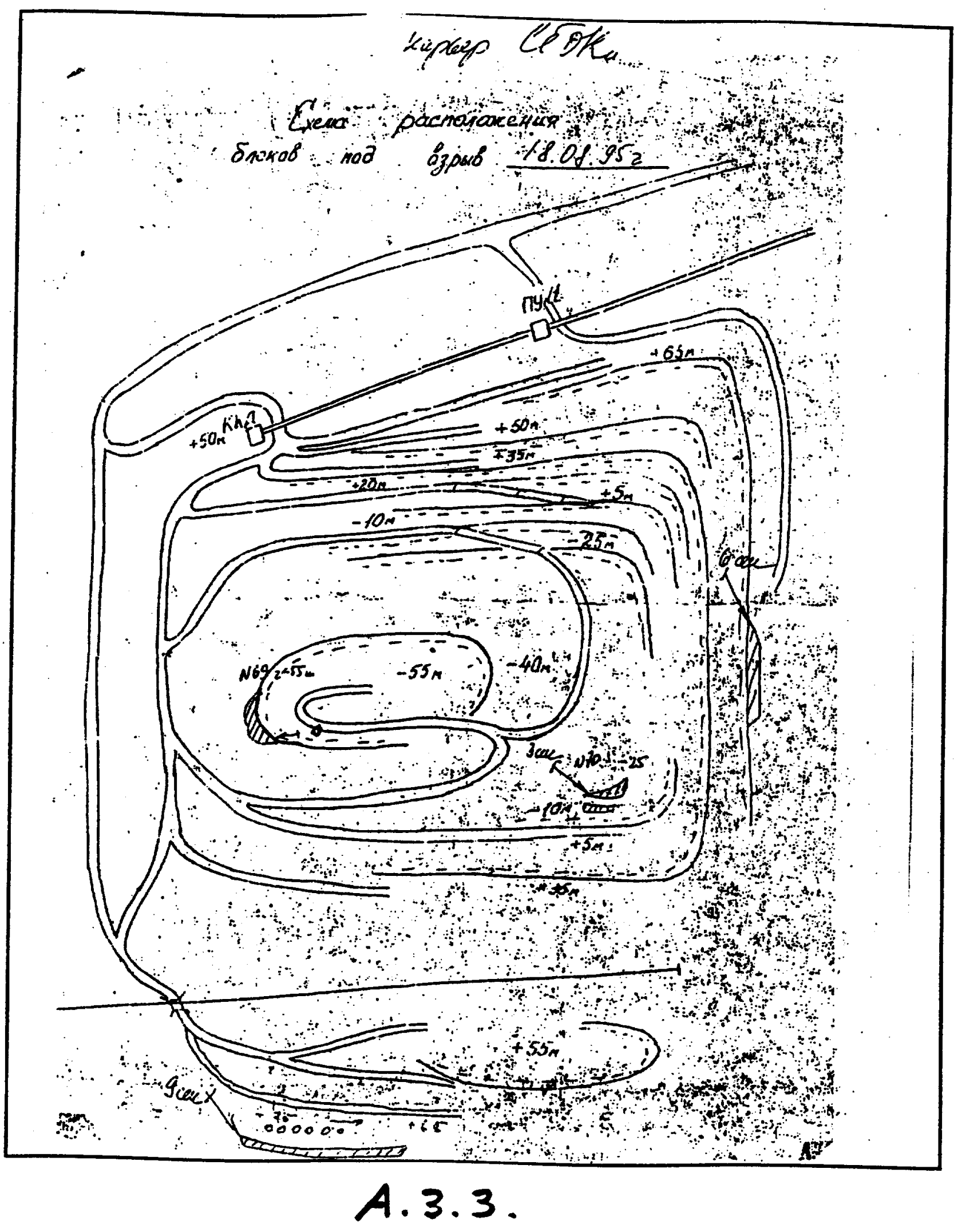




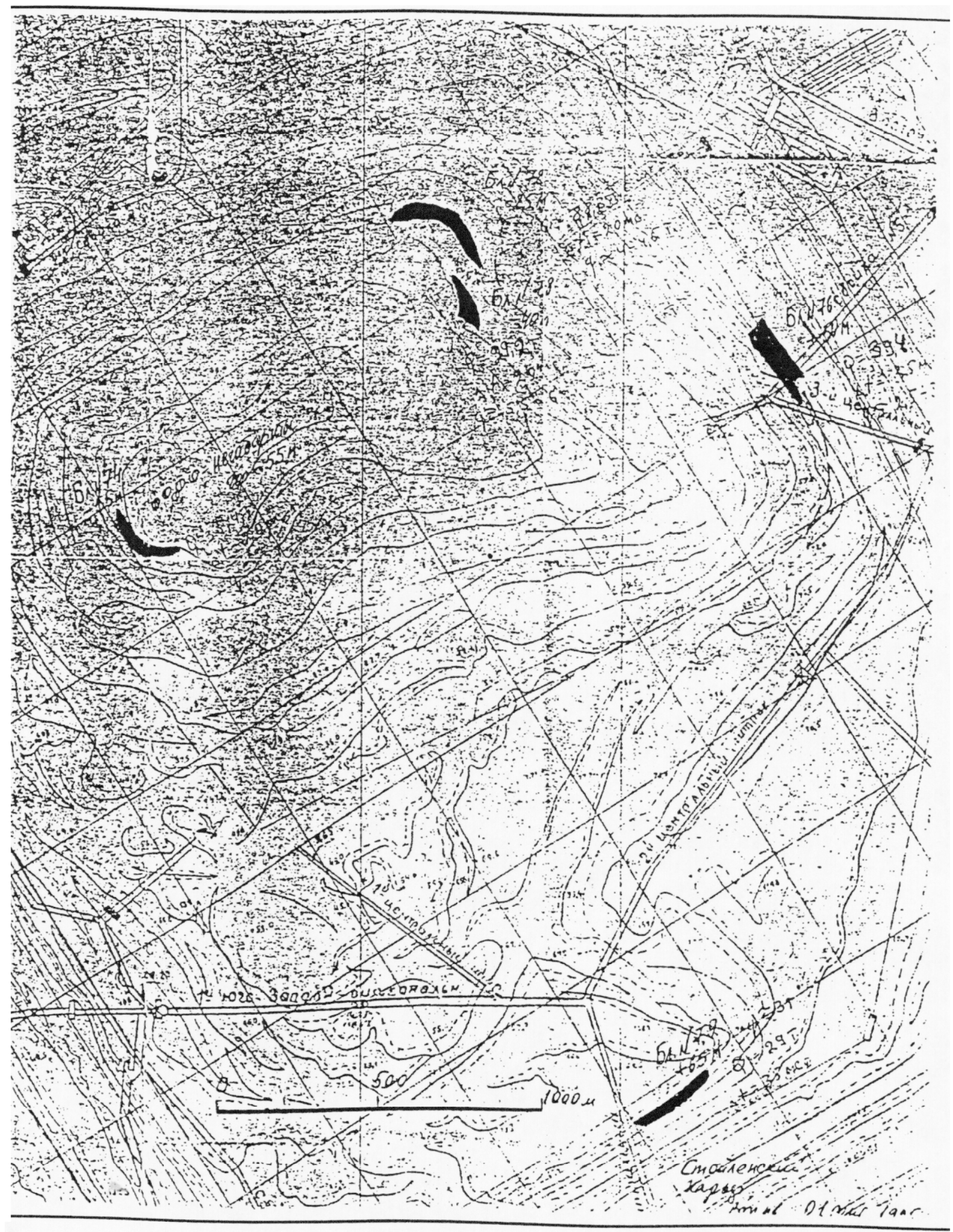

A. 3. 4 . 


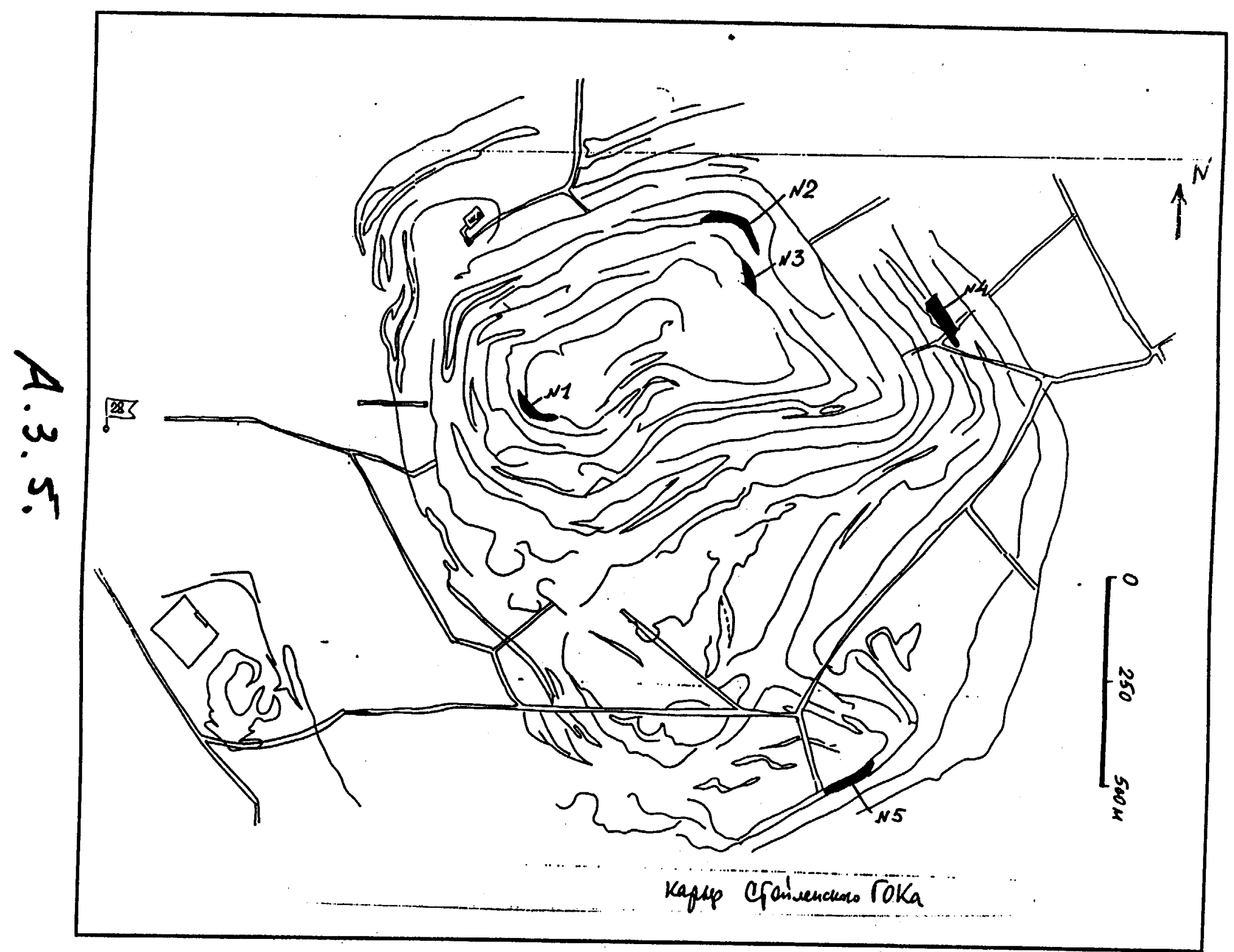




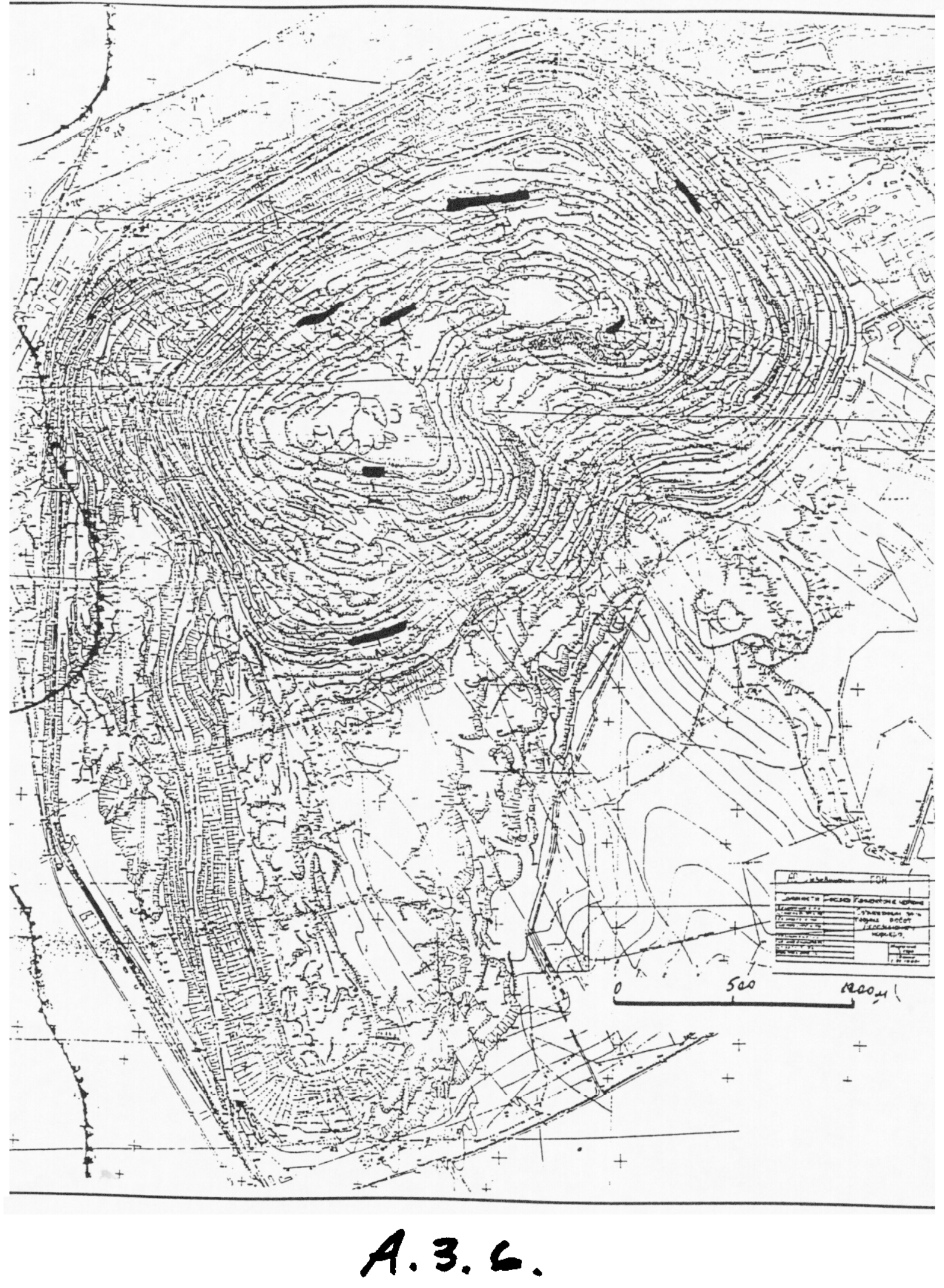


Appendix 4: Video/movie of the detonation of a single block from the blast of September 7, 1995, at Lebedinsky GOK.

Quicktime movie of ....

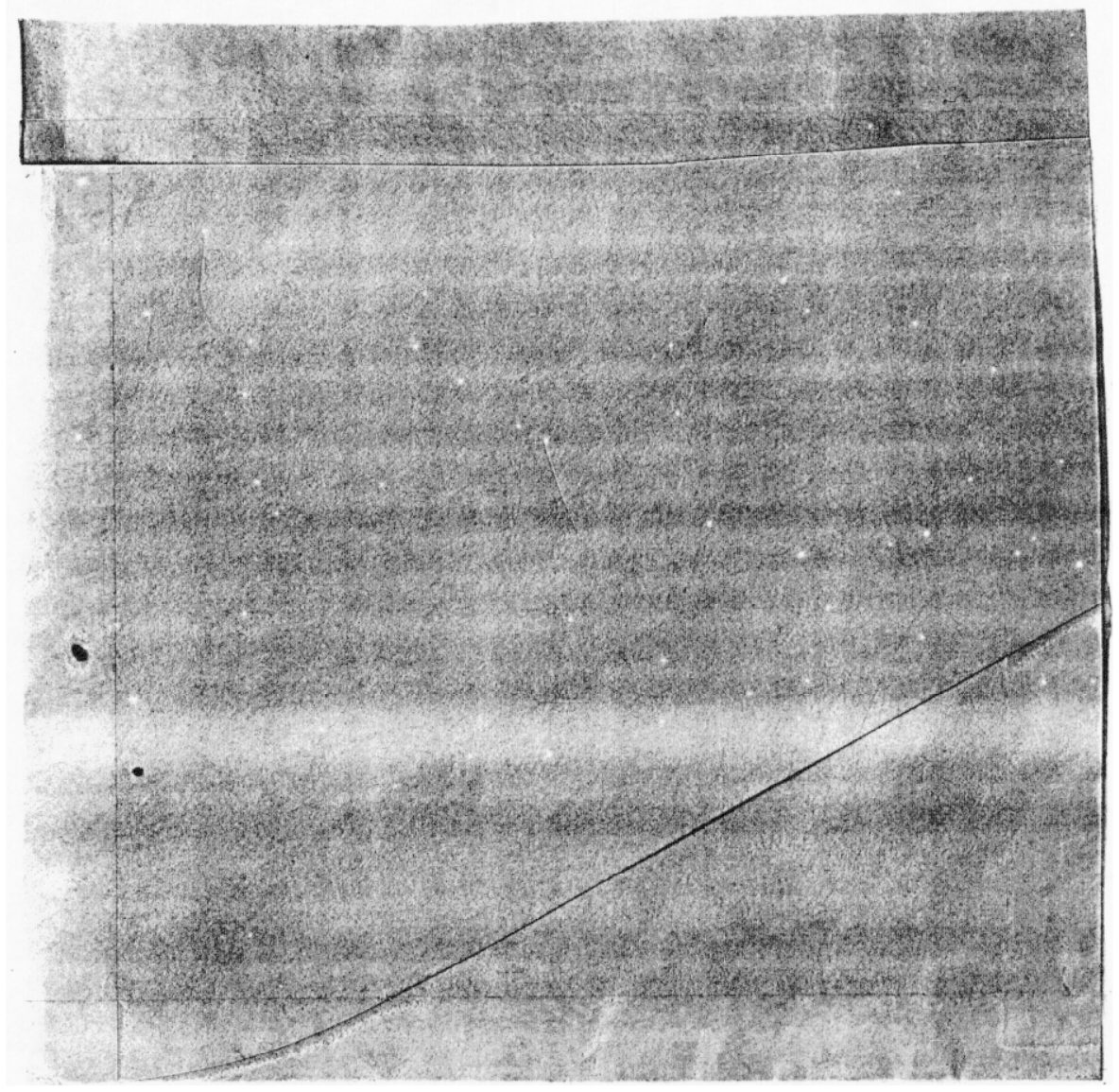


Appendix 5: Seismograms for blasts recorded in Aug.-Sep., 1995.

Events are identified by the year and Julian day on which they occurred. To obtain blast information, compare with Table 7. 
Svoboda 230.09 .40 .52 .46

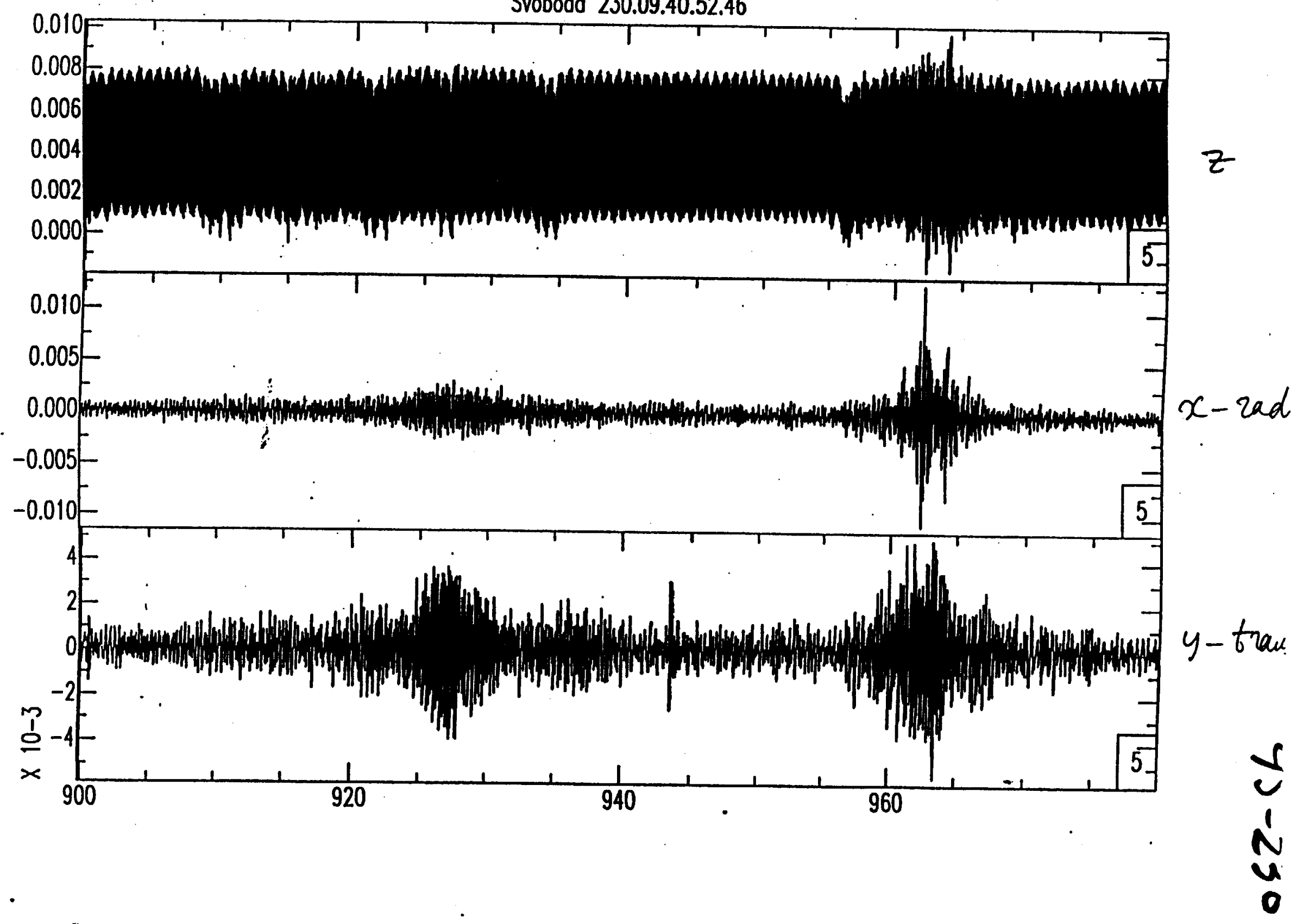



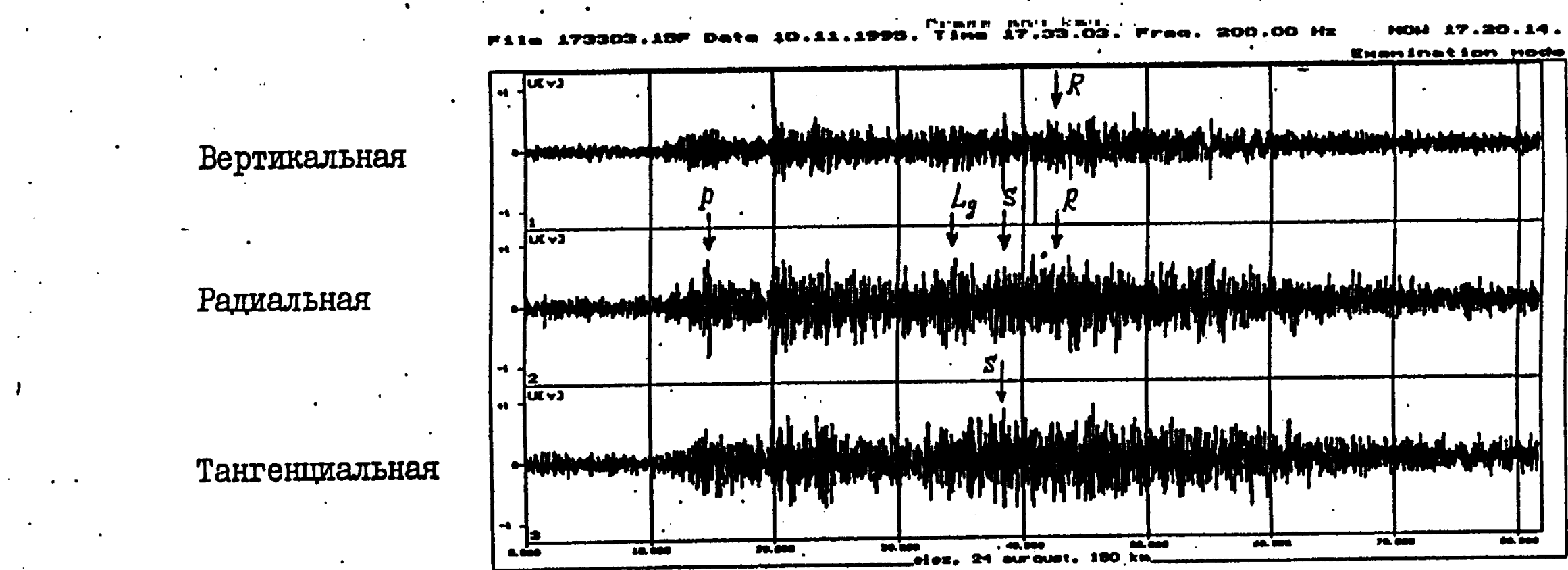

$$
0-80 \text { ceк }
$$

Взршв на Јебединском ГОКе 24 aвгуста I995r. Cейсмопункт в Г.Елец, әшщентральное расстояние $\mathrm{s} I 50$ ісм Амплитуды волн: $P_{x}=7,8 \mathrm{MkM} / \mathrm{c}, L_{g x}=6,9 \mathrm{MKC} / \mathrm{c}, S_{y}=8, I \mathrm{MKM} / \mathrm{c}$ 


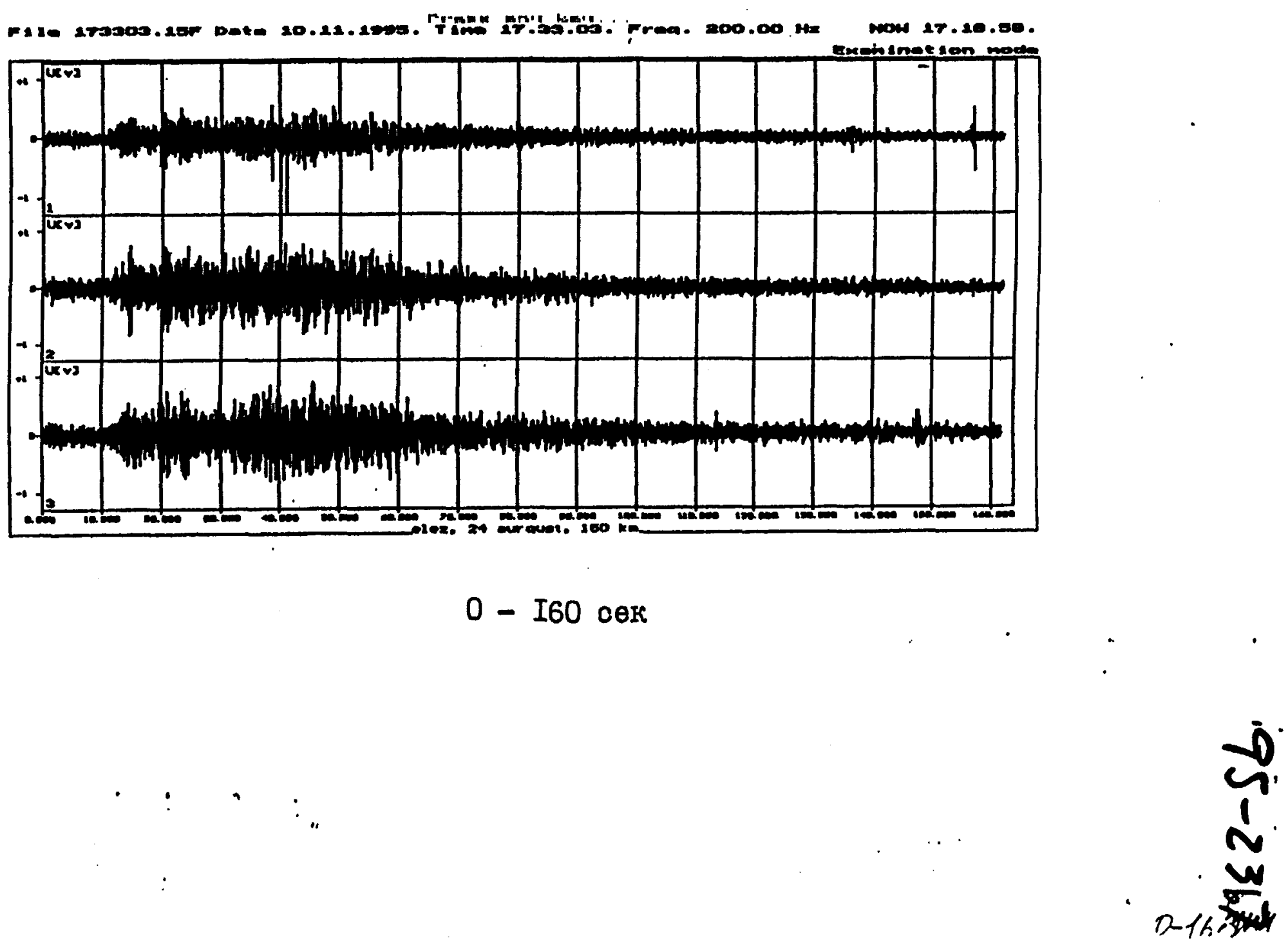




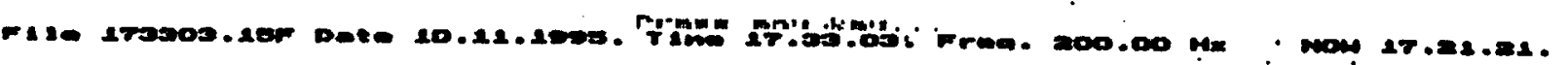

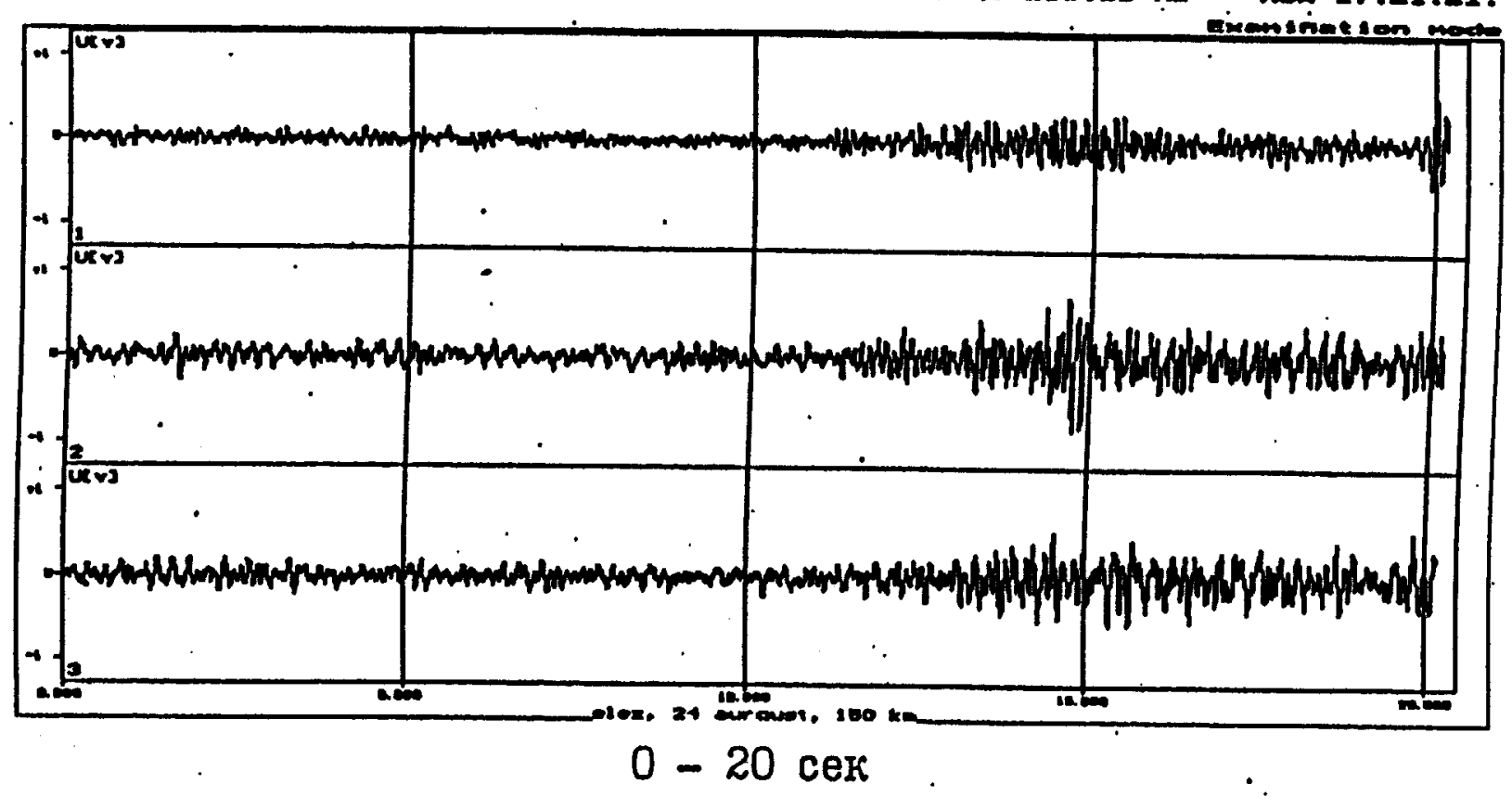

$0-20$ ceк 


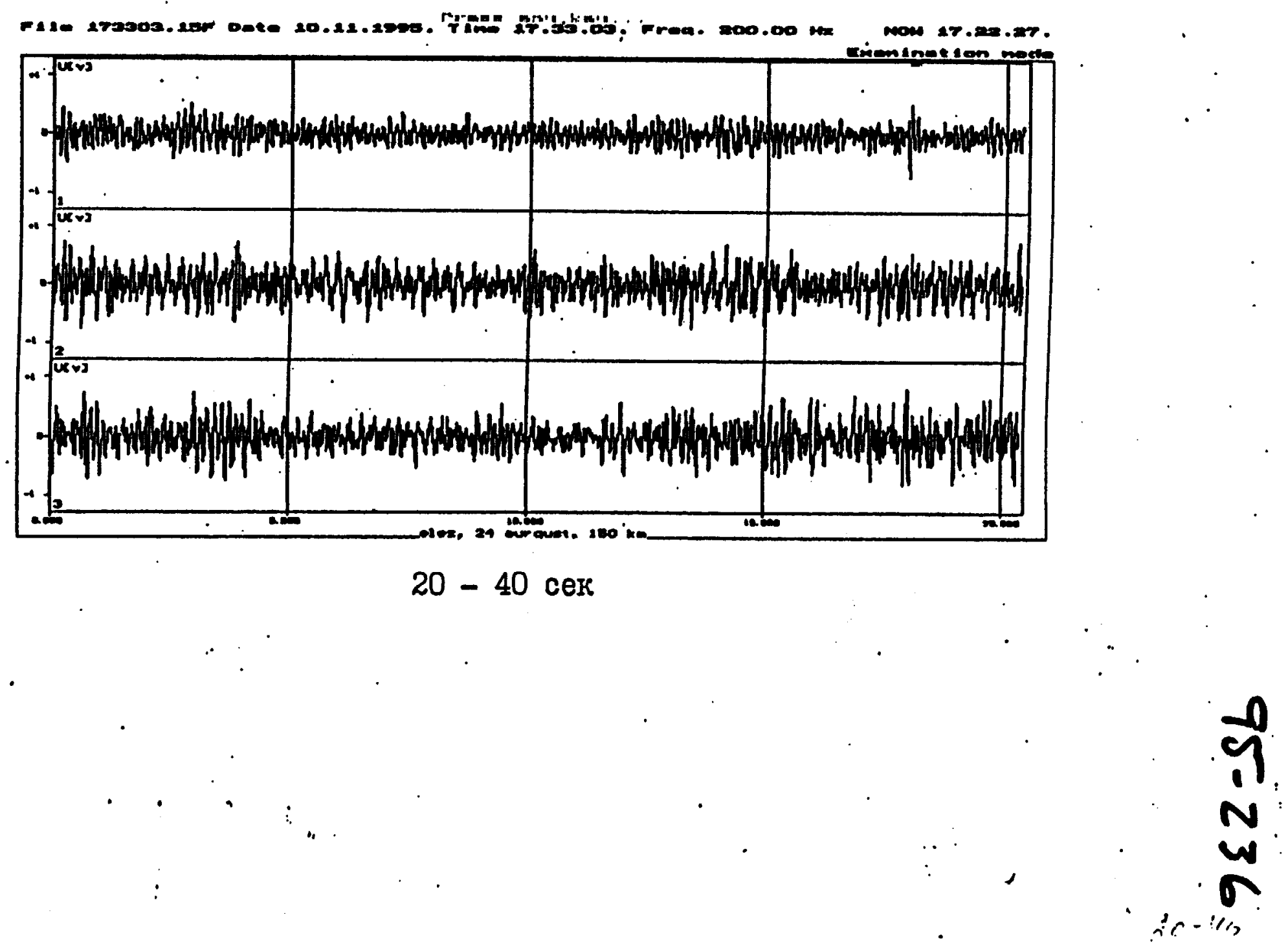




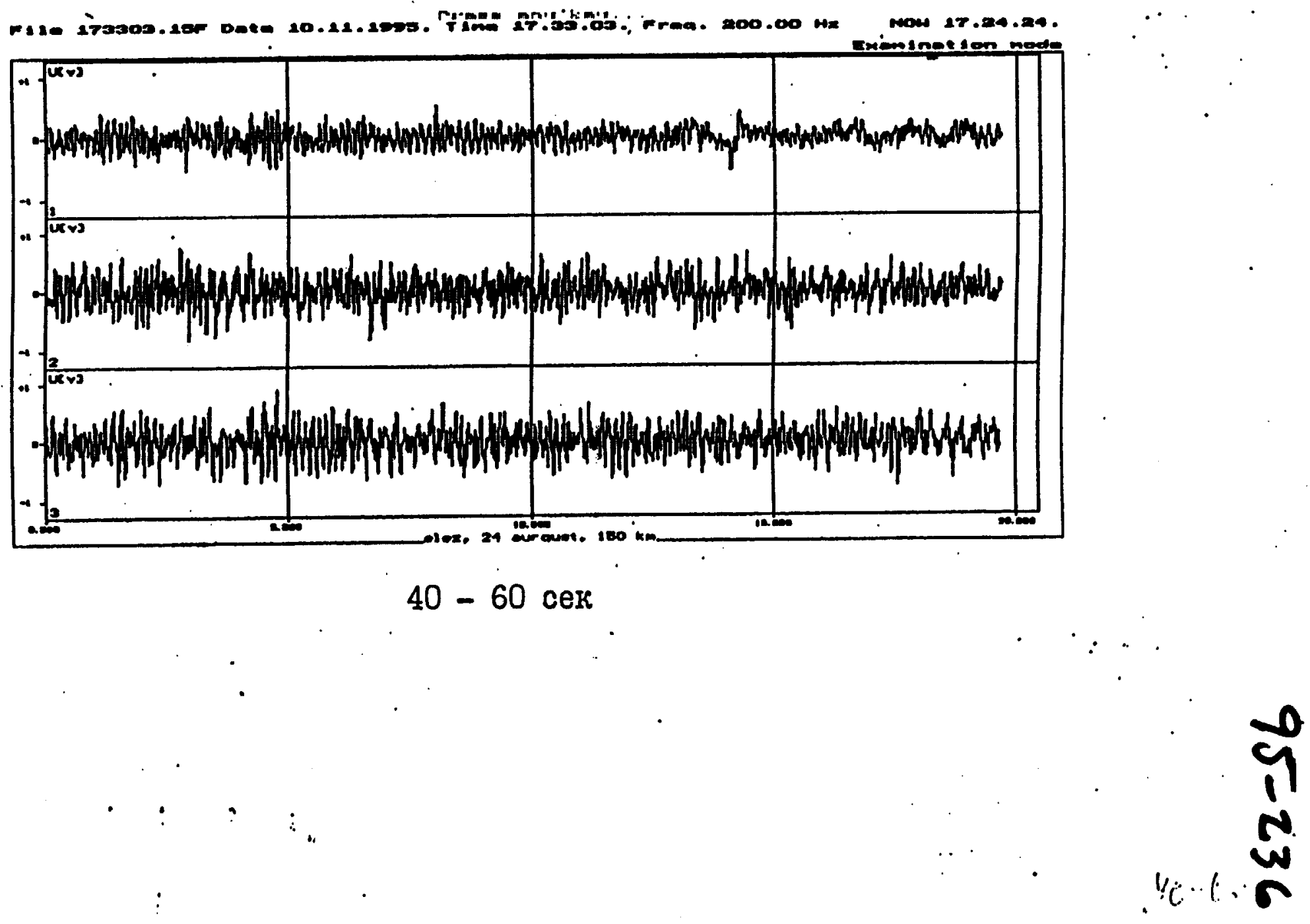




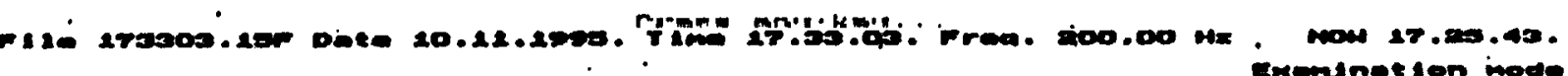

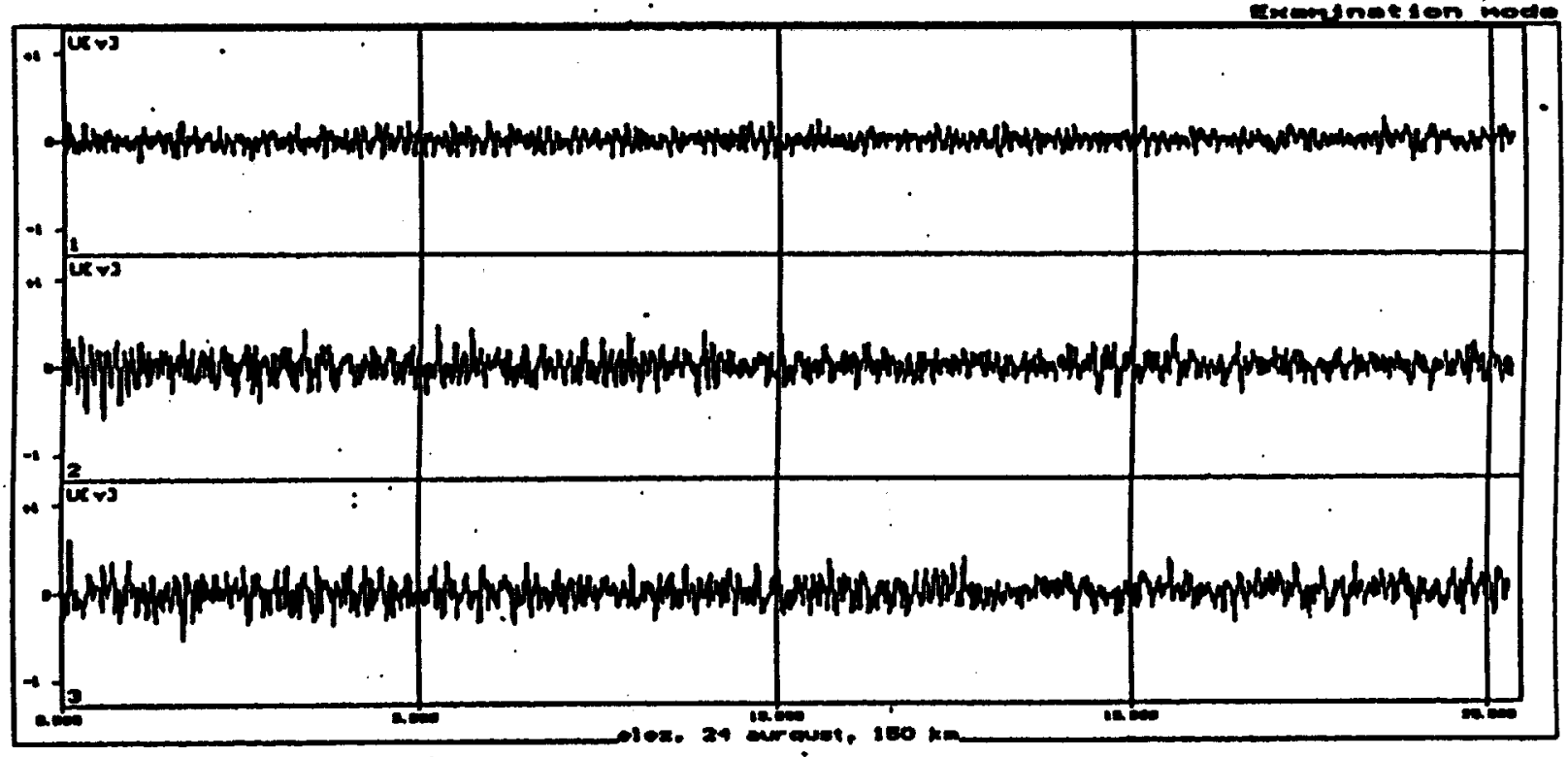

$60-80$ сек 


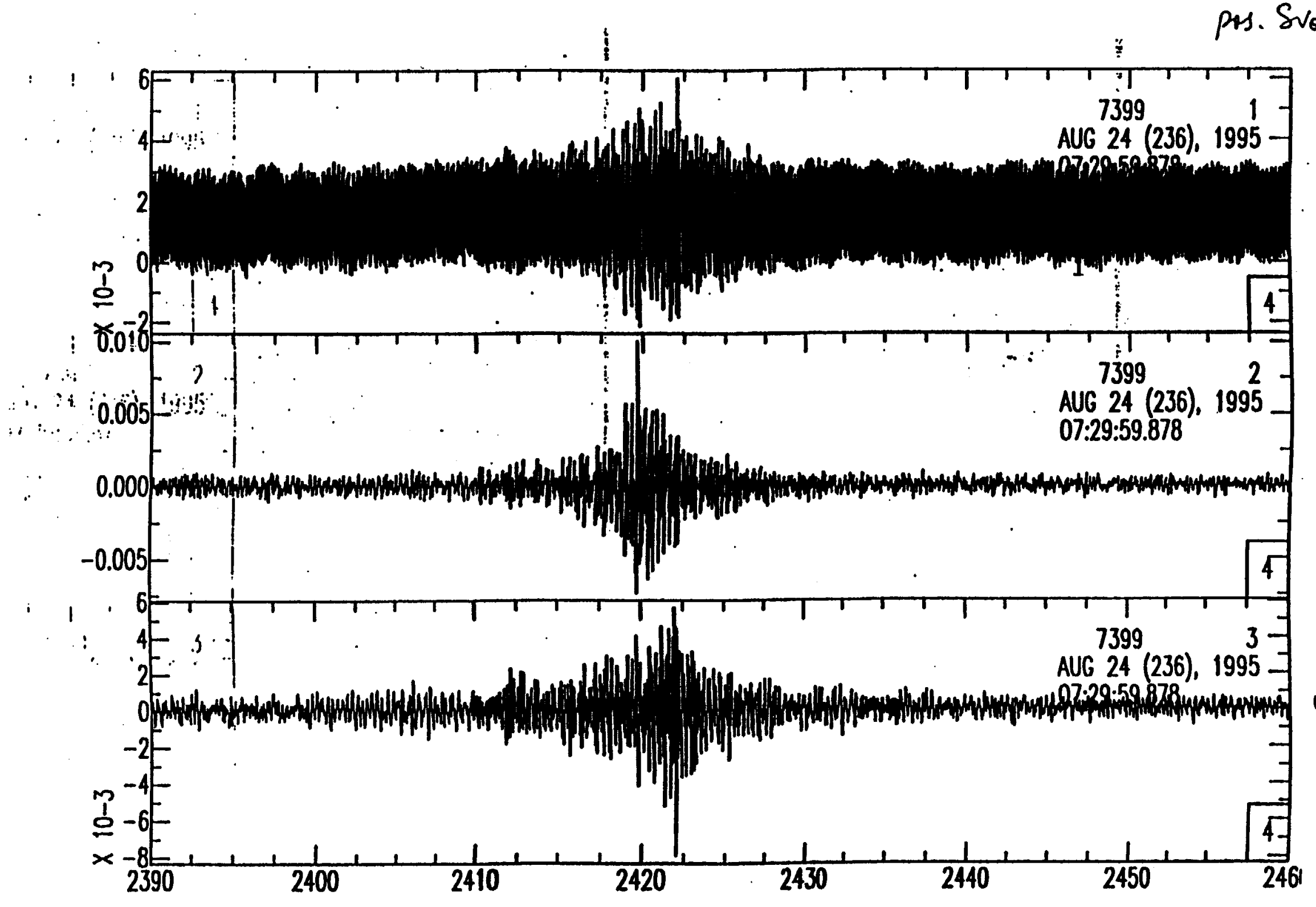




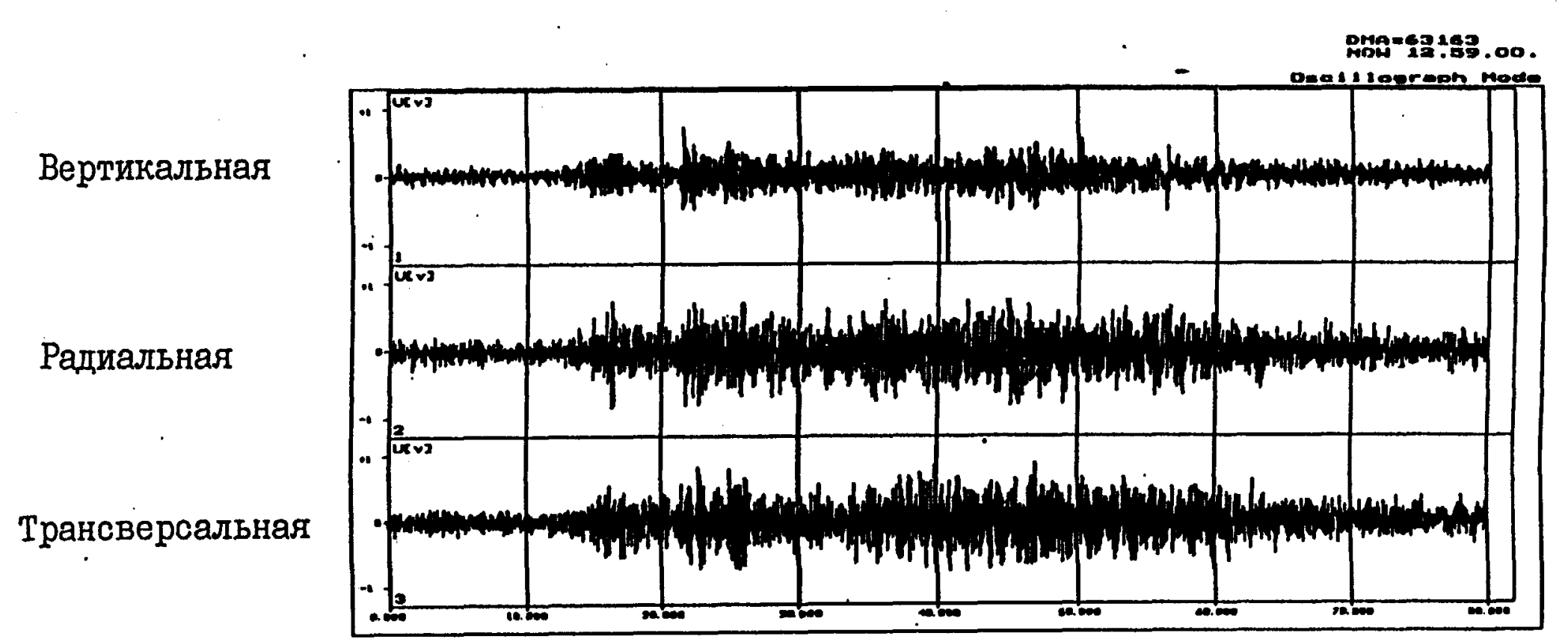

Взрыв на Лебединском руднике.

$$
24.08 .95
$$

Сейсмопункт влец

Эгицентральное расстояние I50 км.

Масштаб записи I - $0.1 \mathrm{~mm} / \mathrm{ce \kappa}$ 
RMA" 13.09 .20 .

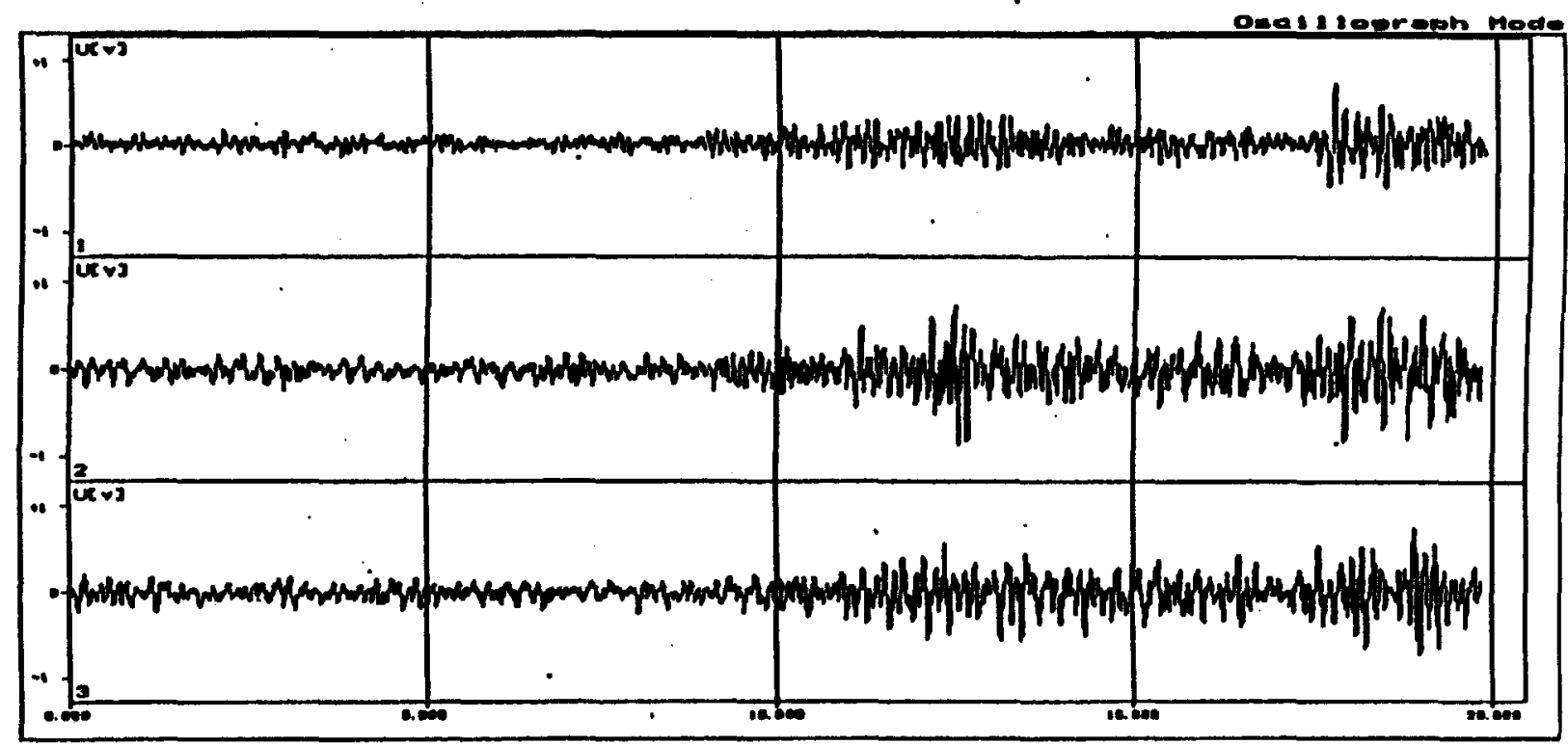

Сейсмопункт Елец.

$0-20$ сек.

Первые 20 секунд записи. 


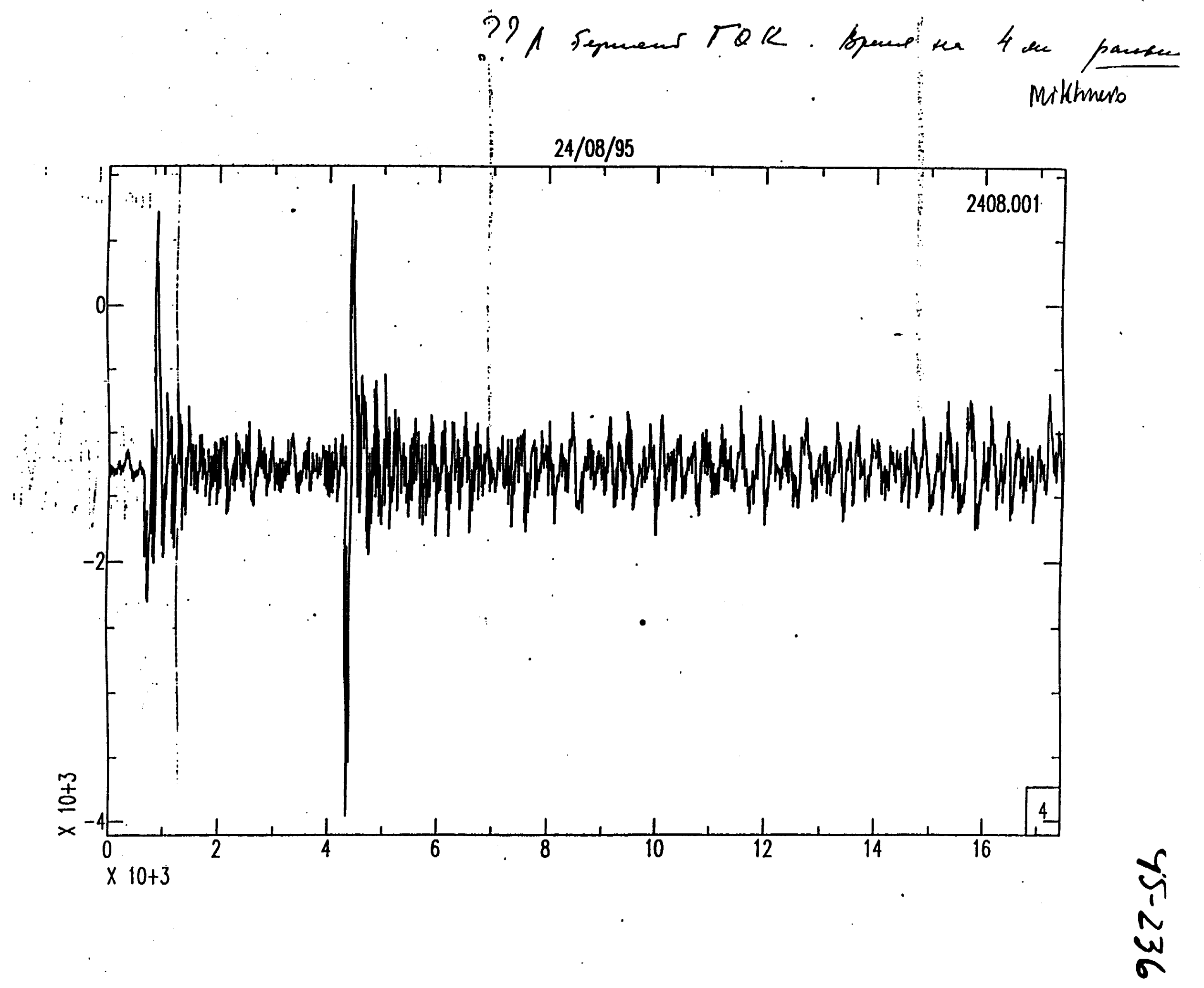


KMA ( dergroum

26.08 .95

pas. Sroroda

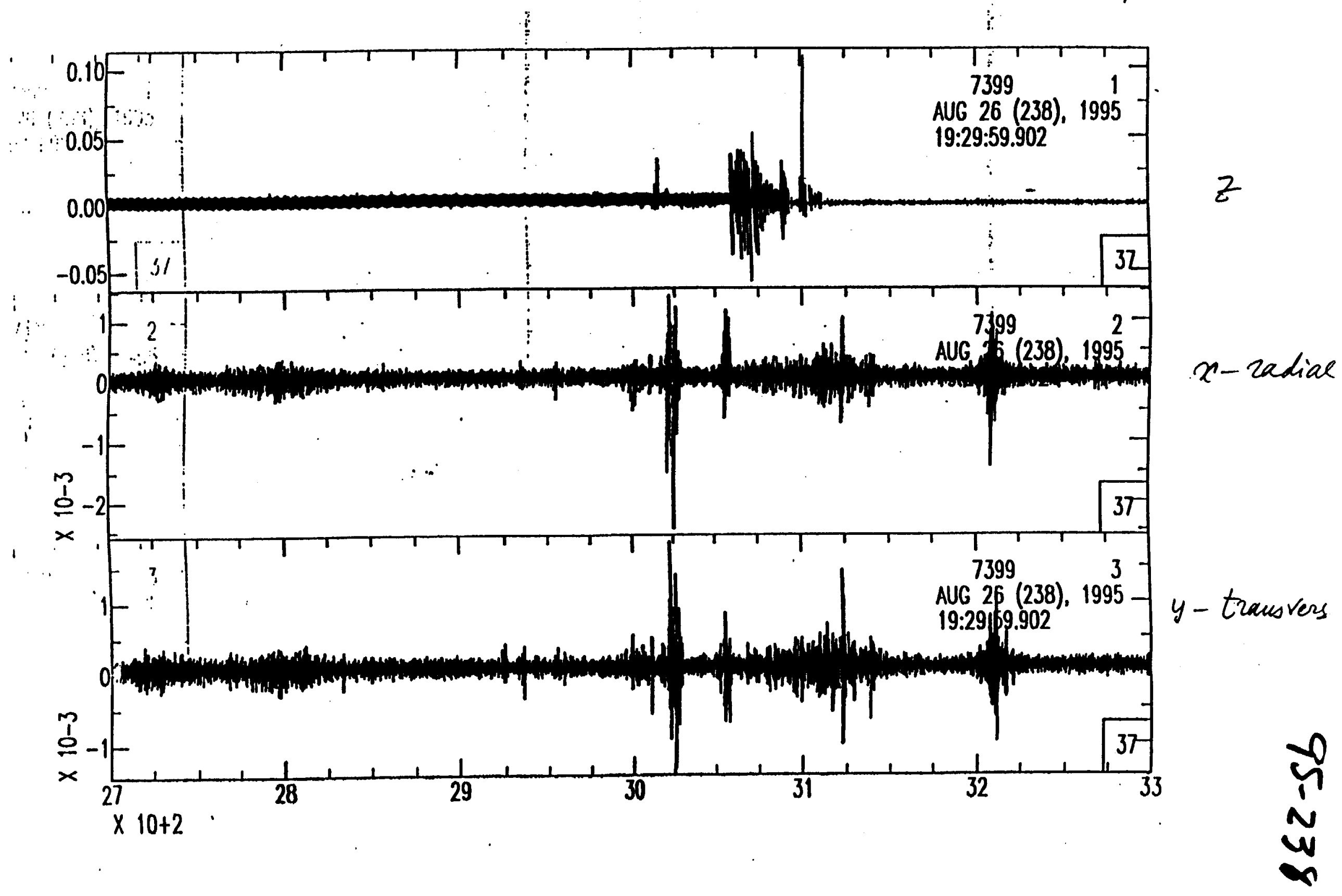


Mikhailor-ty or.c. 15 pos. Svoloda

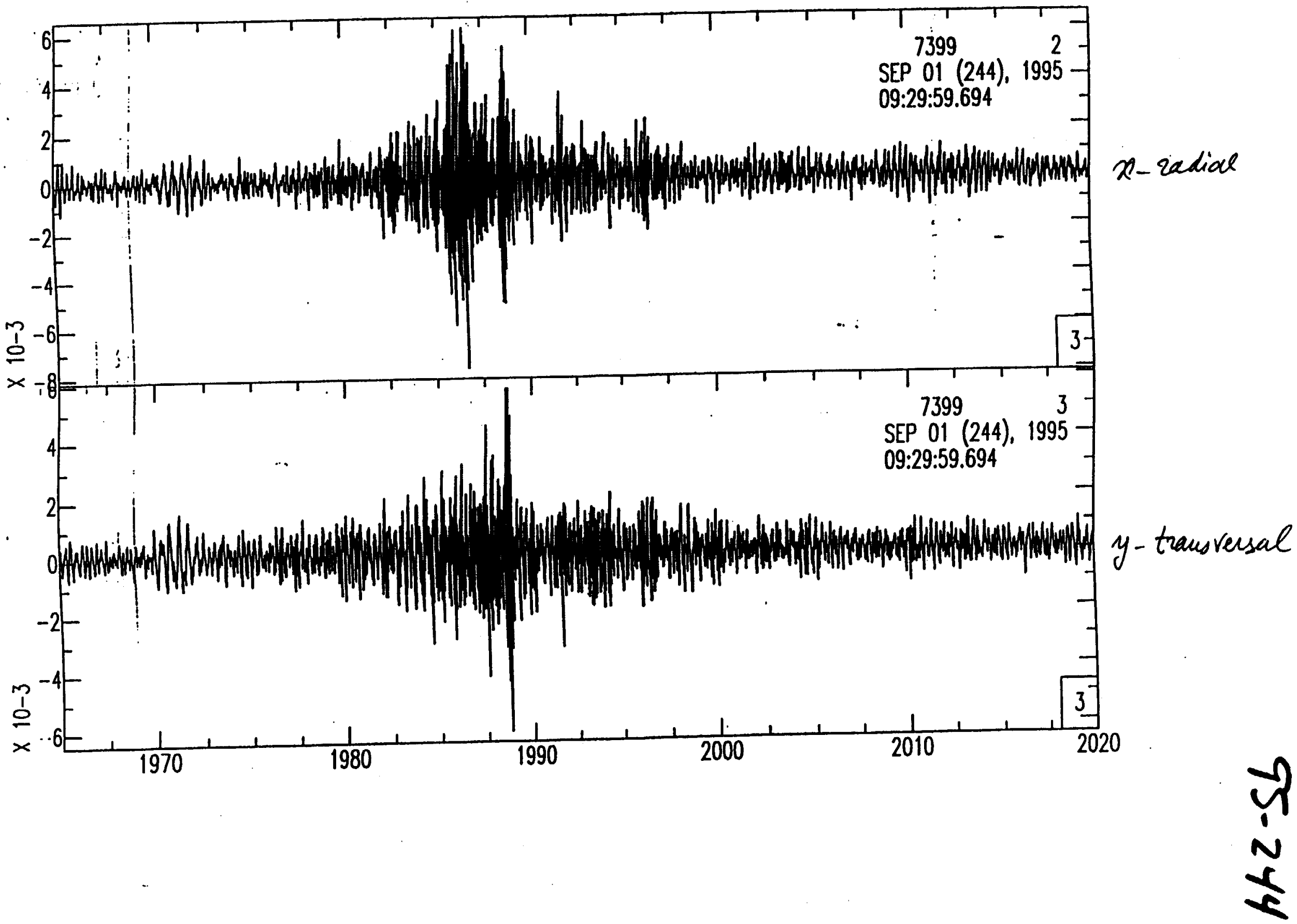




\section{Mikhailorshy 0 tog.95 ( \\ pos. Tim}

file a501 date 95-9-1 time 8:0:0. $Y$-ax $f=10$.

$A \cup=-3.154$ AuSq $=26.872$ AUA $=20.399 \quad D=1.7353$

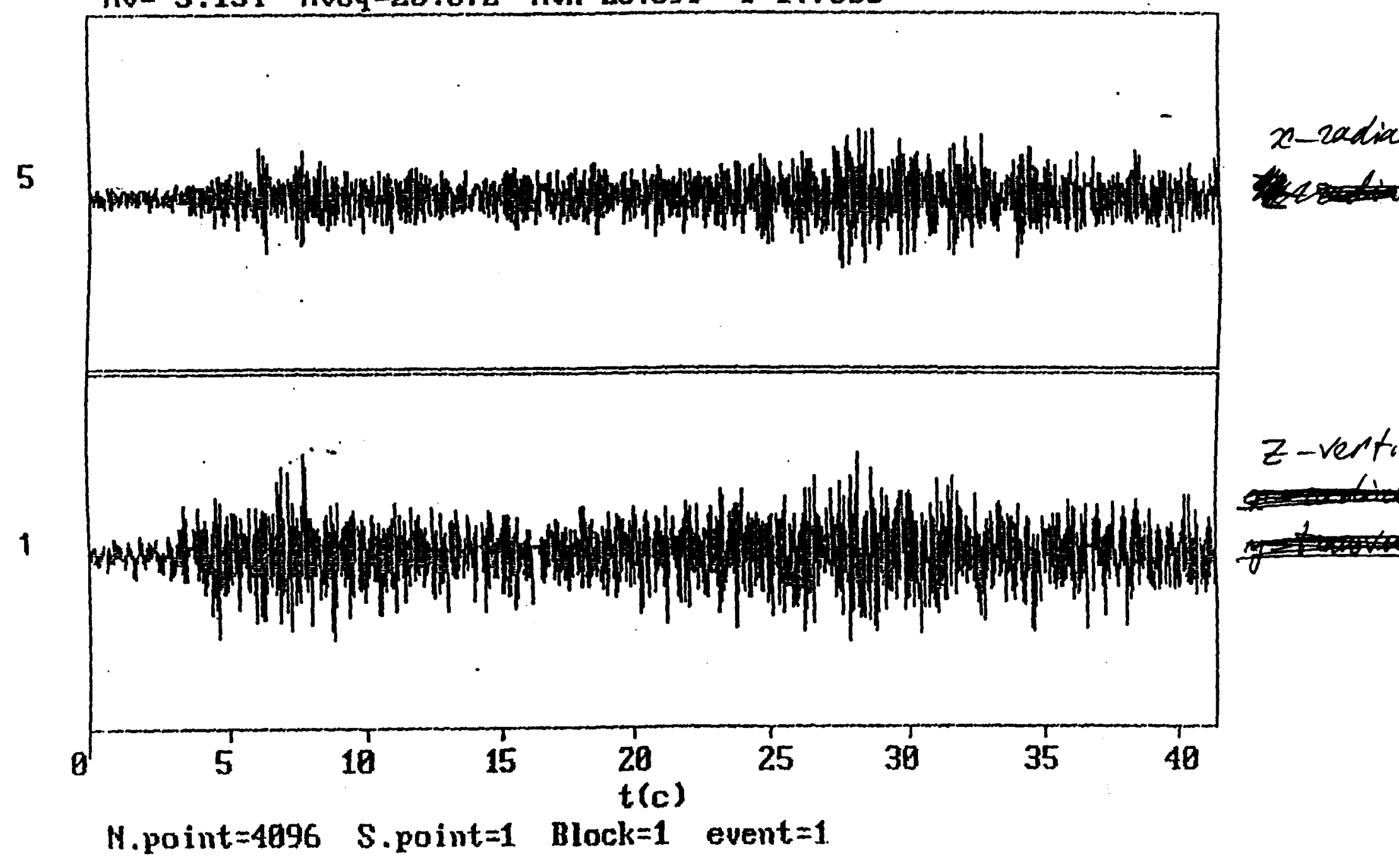


Stailenstey Gou

$$
\begin{aligned}
& 01.09 .95 \text { ( } 205 \\
& \text { pos. Tim }
\end{aligned}
$$

file a501 date 95-9-1 time 10:0:0. Y-ax $f .=20$.

$A \cup=14.429$ AuSq $=75.770$ AuA $=59.407 \quad D=1.6267$

5

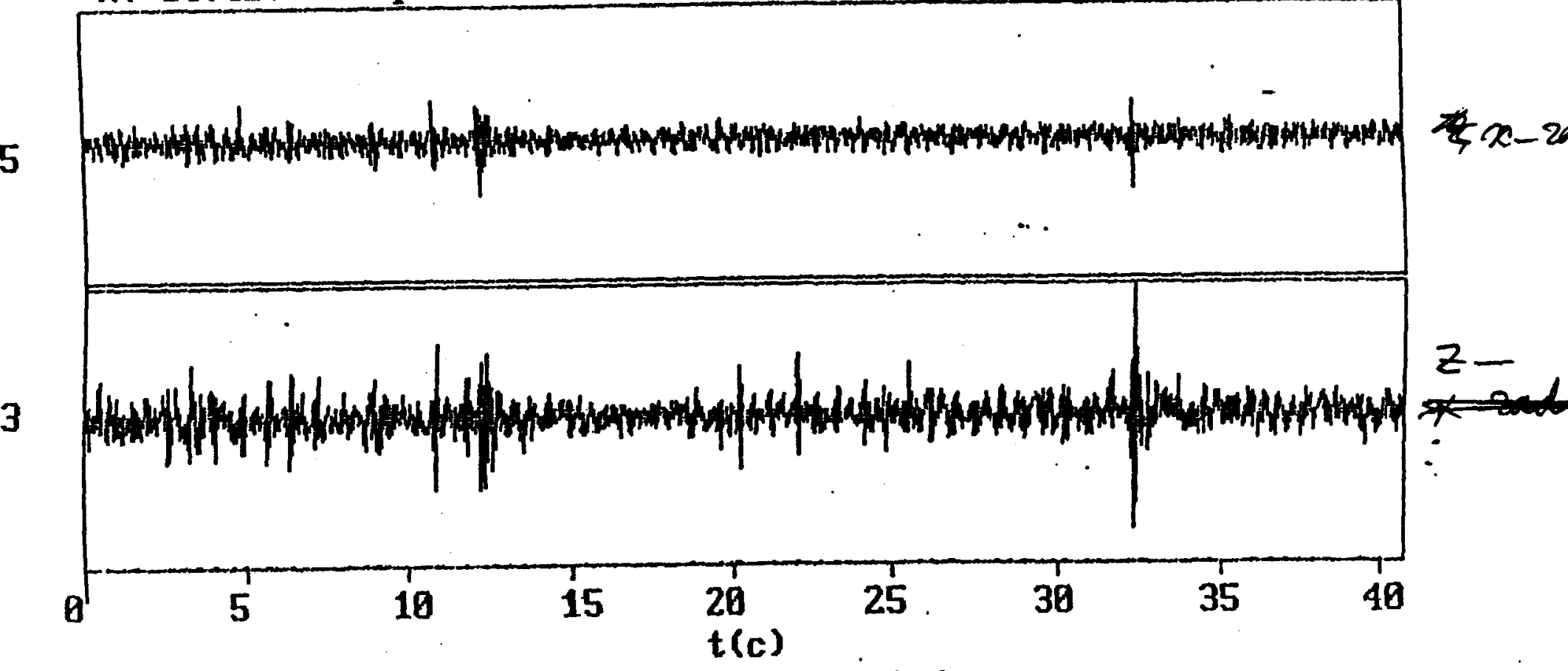

N.point $=4996$ S.point=1 Block=1 event $=1$ 
pos. Svobode
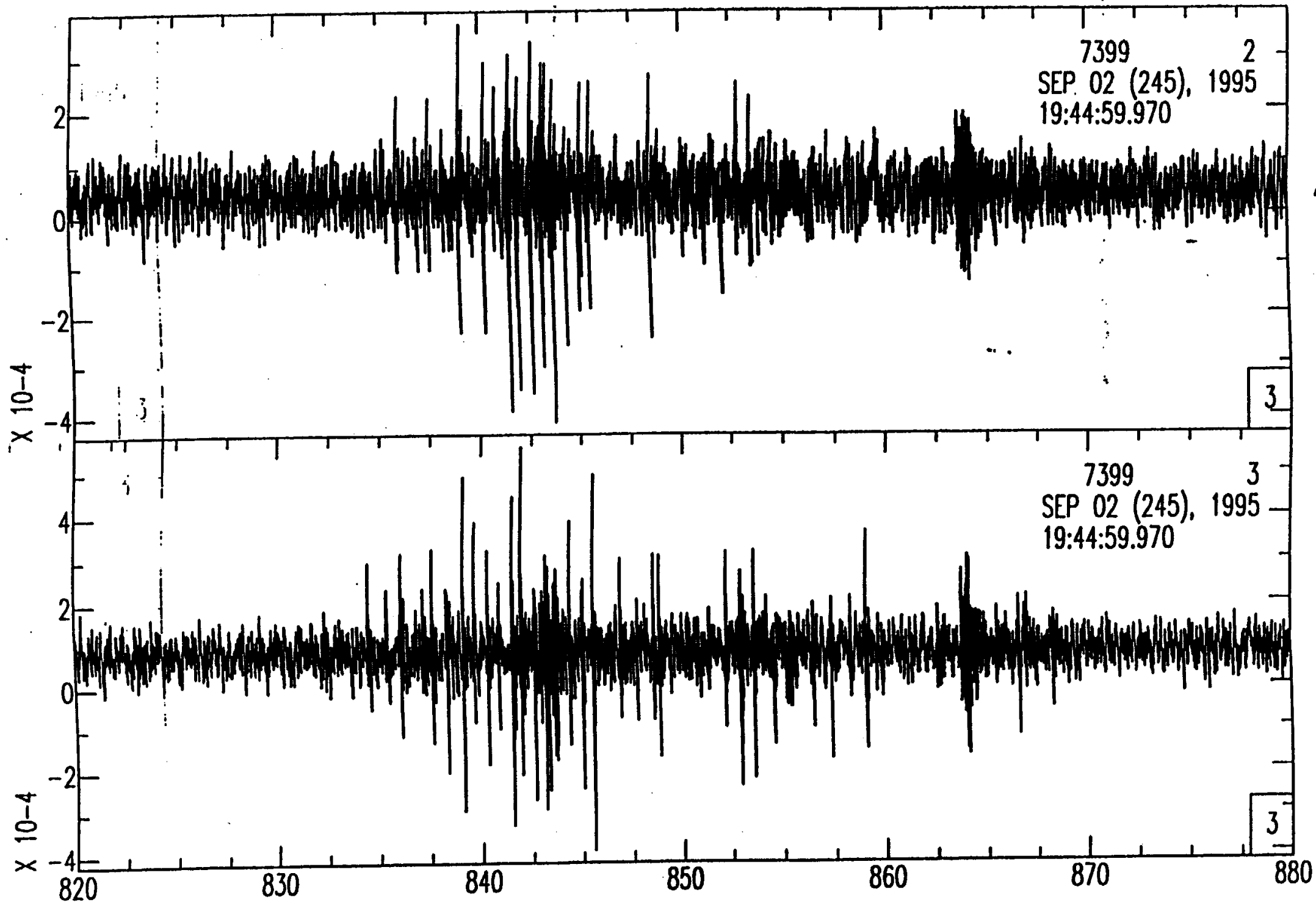

$x$-radial

$y$-trausvasal 
Explosion at Lebedinsky GOK (Sep 07, 1995)

Point of registration: pos. Tim

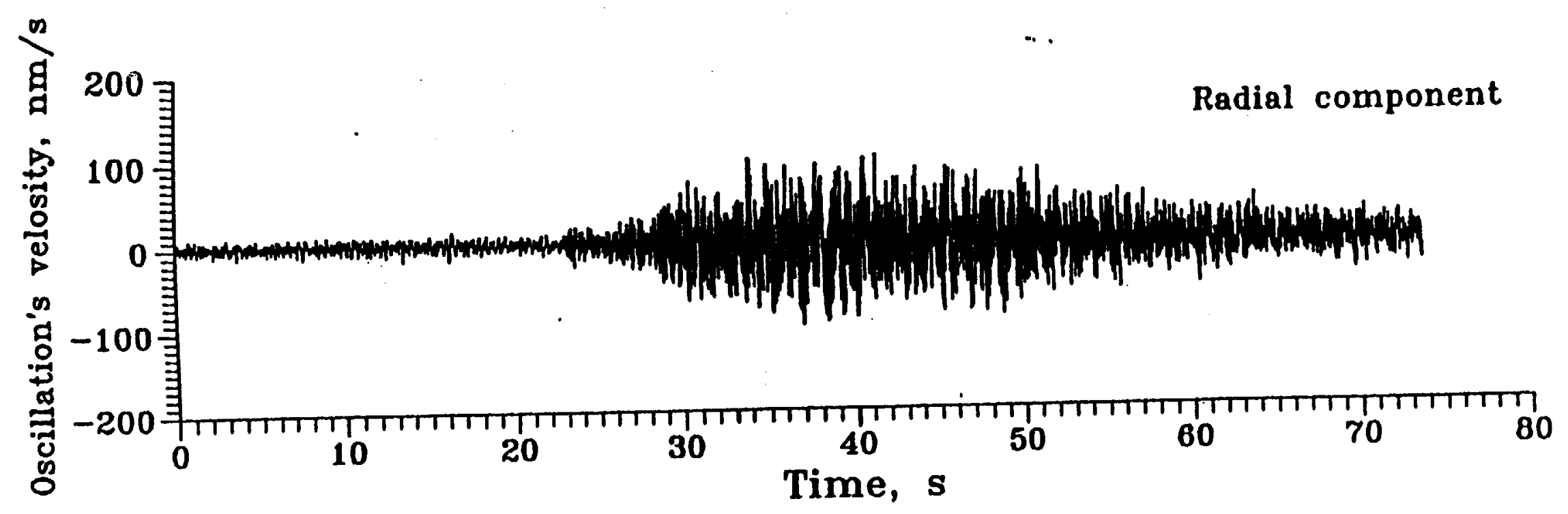




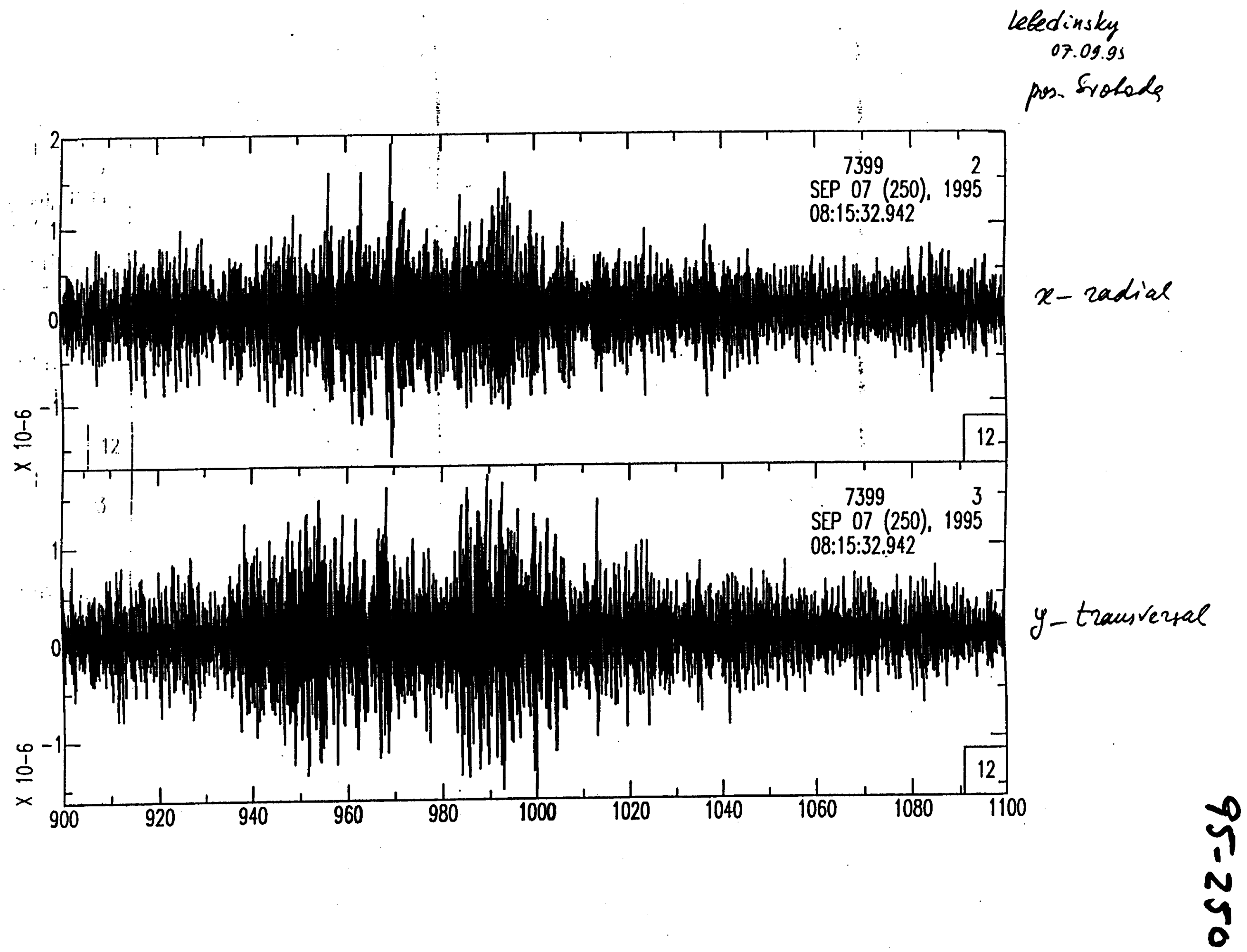


Lebediusty ô

07.09 .95 ( vesus)

pes. Tim

file a501 date 95-9-7 time 8:31:日. Y-ax f. $=10$. $A \cup=5.857$ AuSq $=27.098$ AuA $=15.793 \quad D=2.9439$

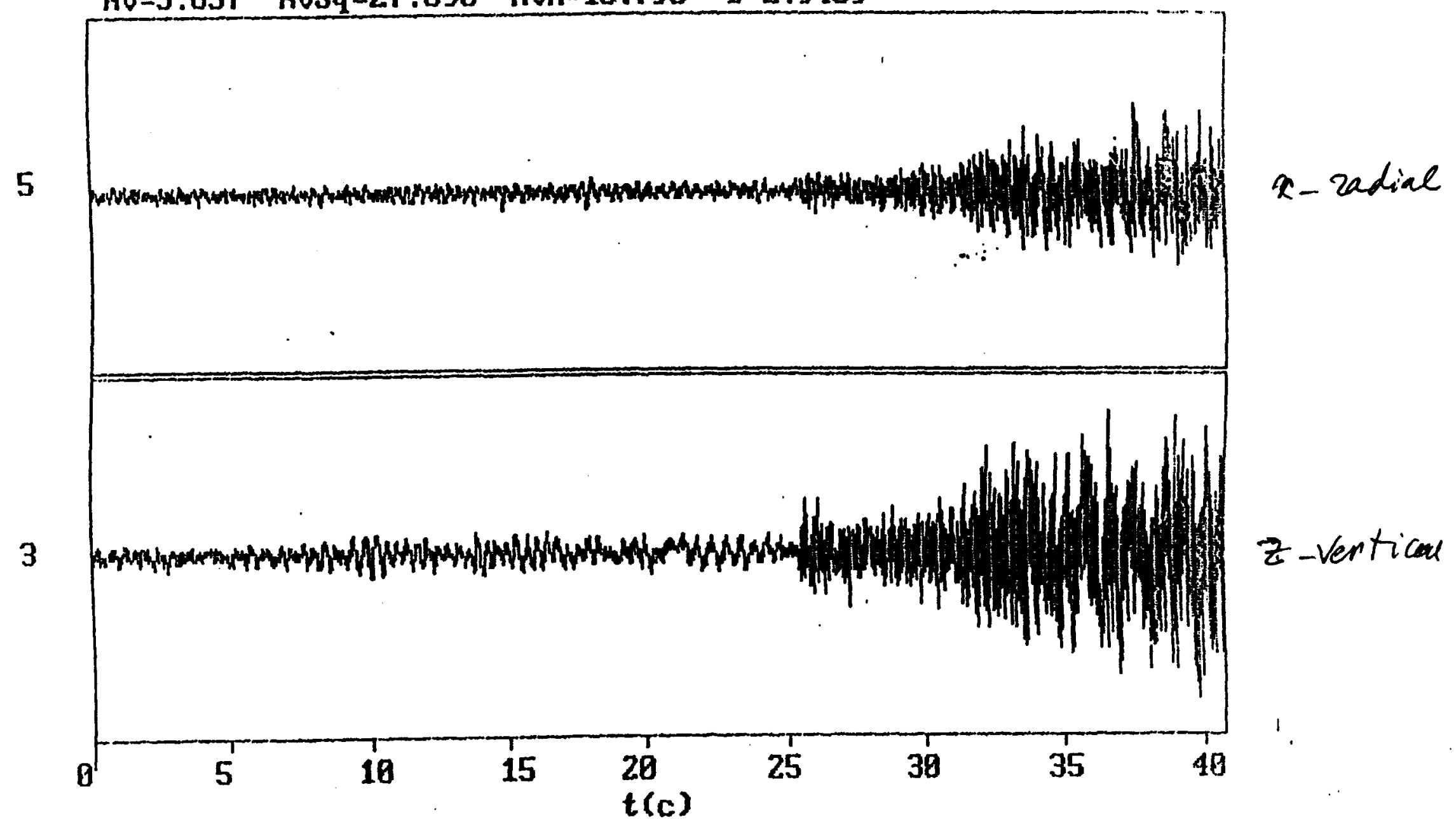

N.point $=4096$ S.point $=1$ Block $=0$ event $=1$ 
Lebediughte som

$$
\begin{aligned}
& 07.09 .95 \\
& \text { pos. Tim }
\end{aligned}
$$

file a501 date 95-9-7 time 8:31:40.804 $\quad Y$-ax $f=10$.

$A \cup=5.340$ AuSq=40.709 AuA $=30.674 \quad D=1.7613$

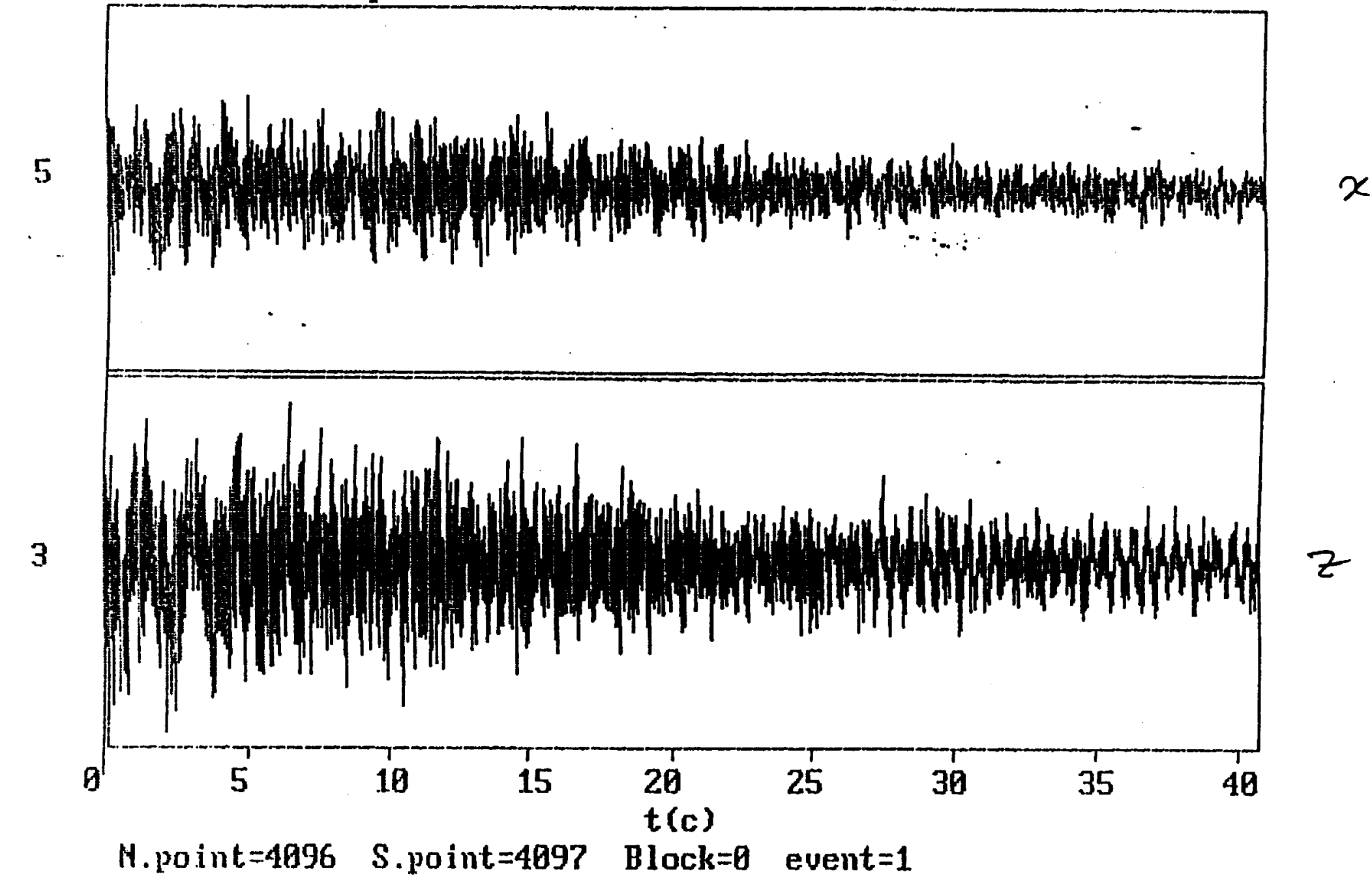




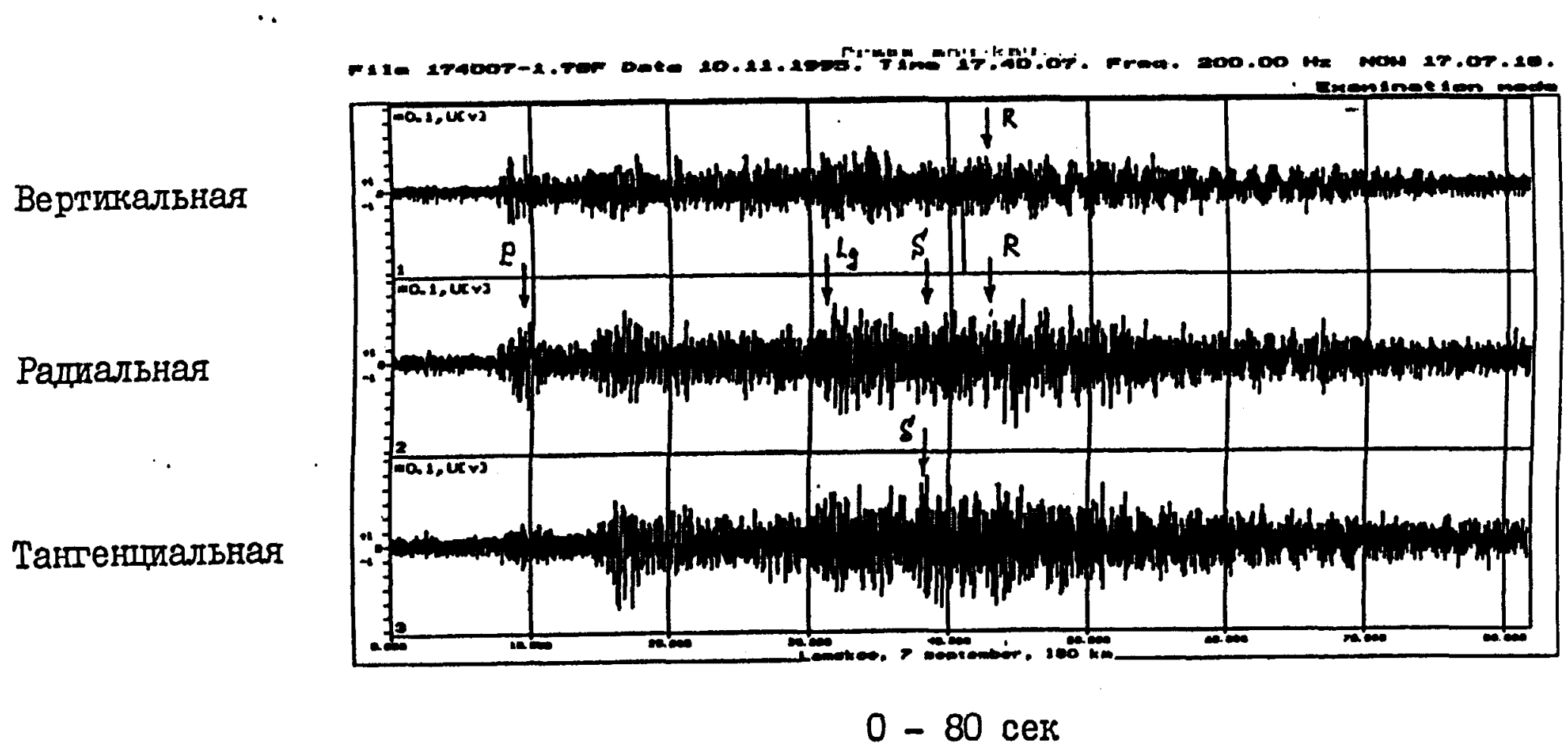

Взрыв на Лебединском ГОКе

7 сентября I995r.

Сейсмопункт в с.Ламское, эпицентральное расстояние I80 км.

Амплитуды волн: $P_{x}=3, I 5 \mathrm{mrom} / \mathrm{c}, L_{g x}=3,8 \mathrm{Mrem} / \mathrm{c}, S_{y}=4,2 \mathrm{Mrem} / \mathrm{c}$ 


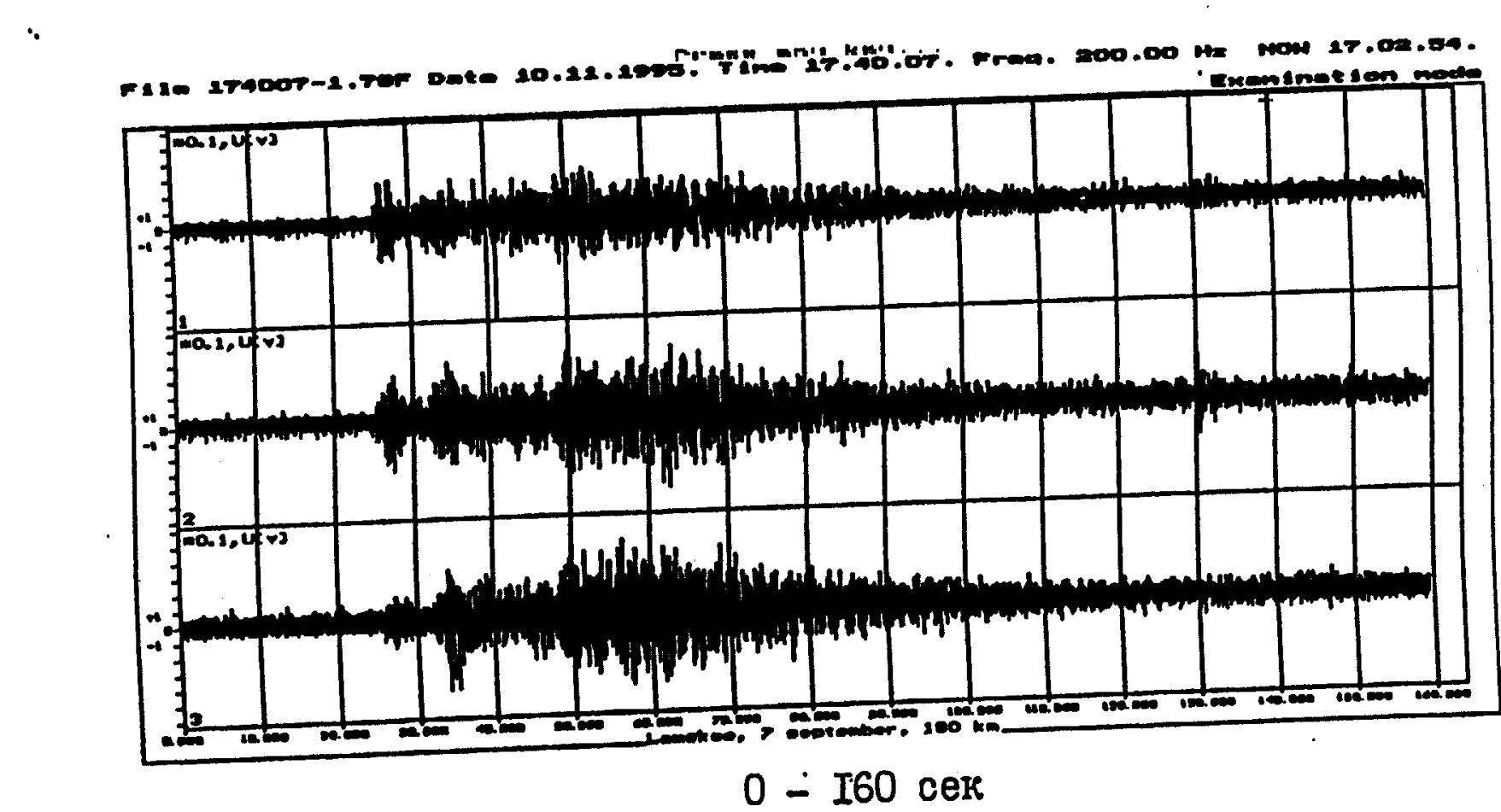




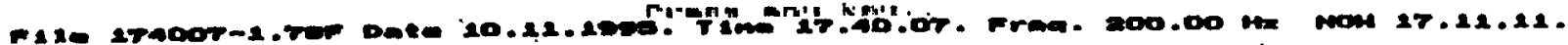

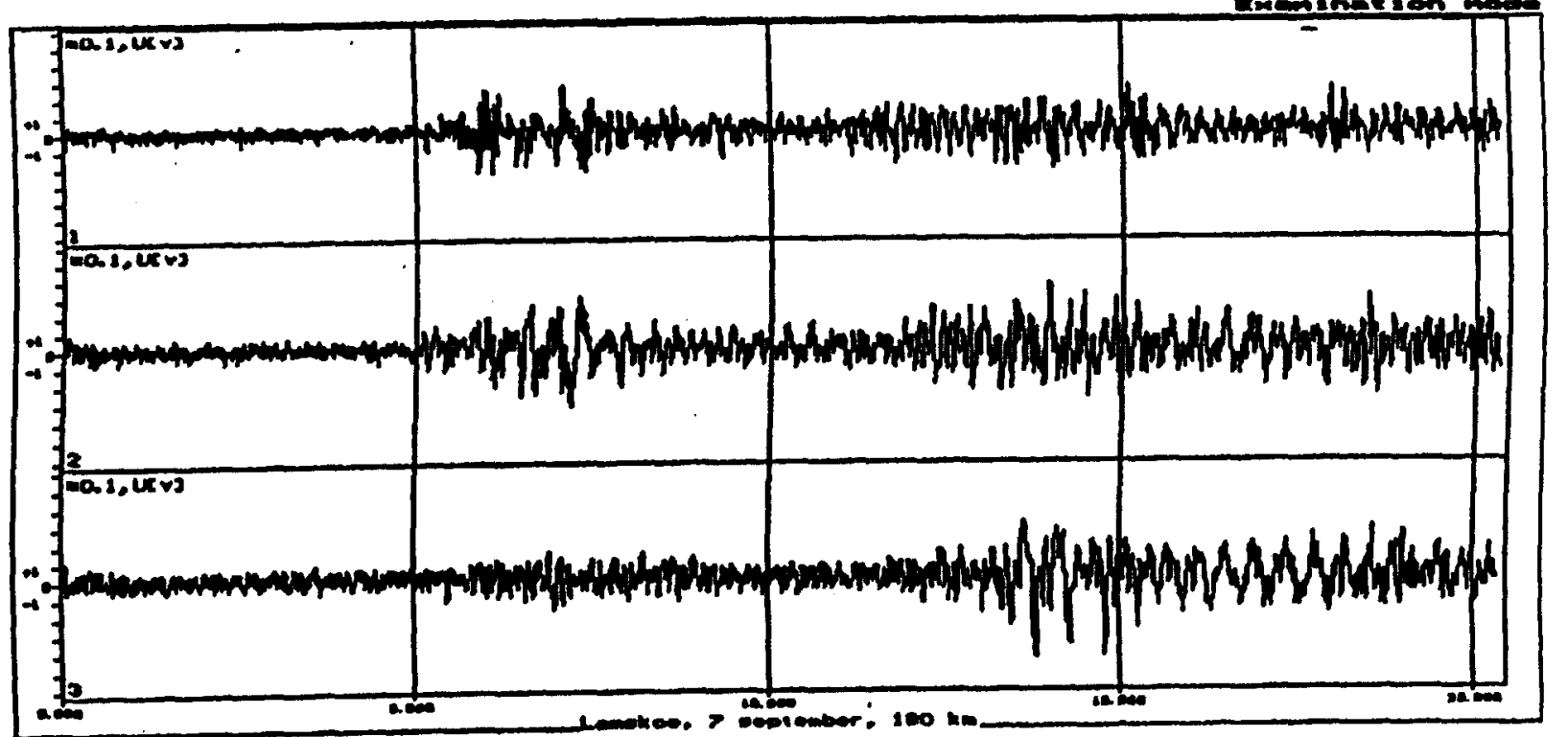

$$
20-40 \text { cek }
$$





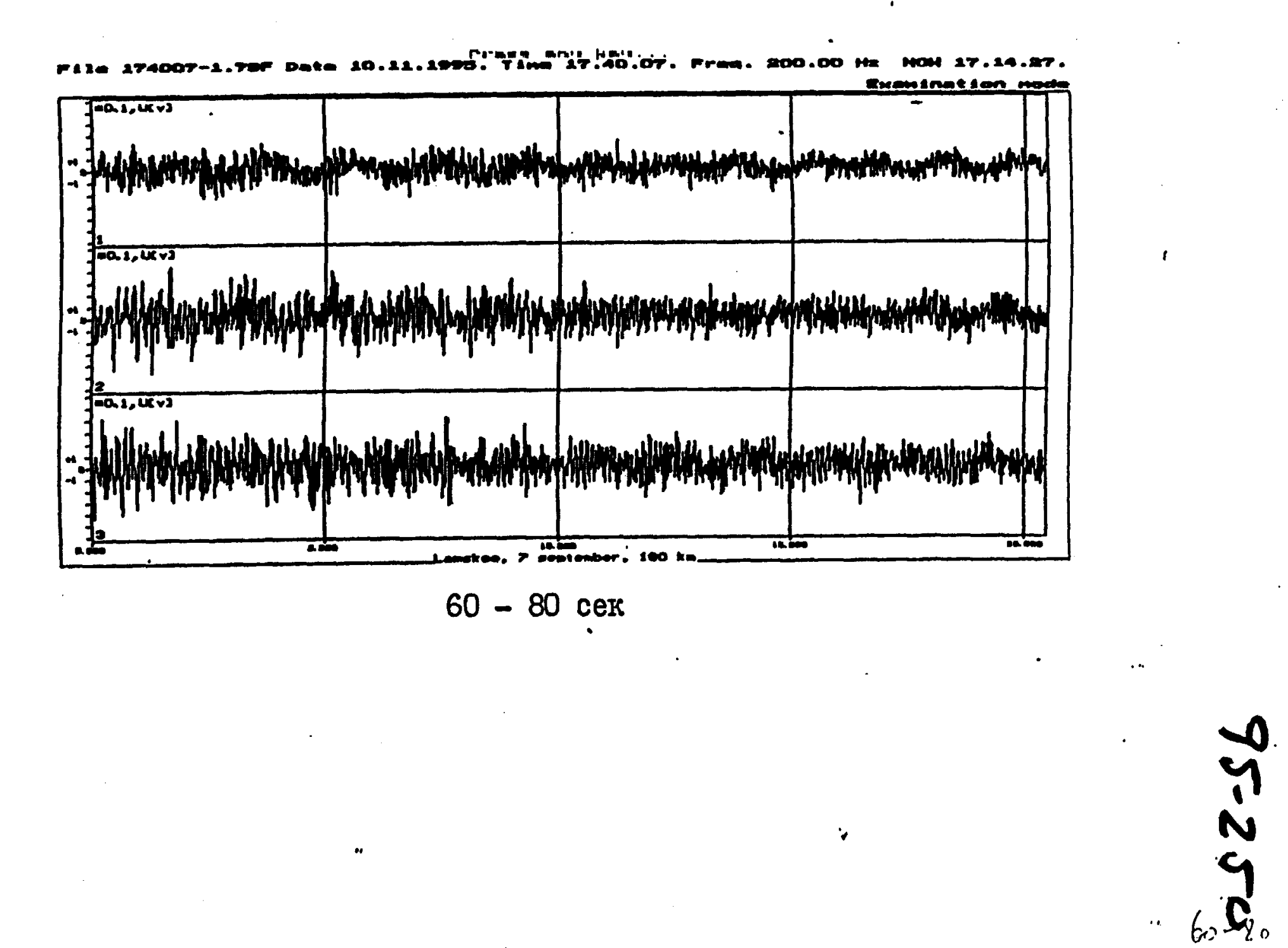




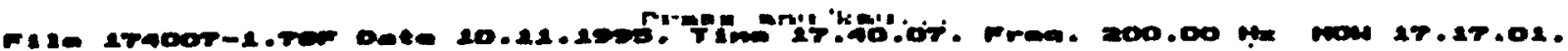

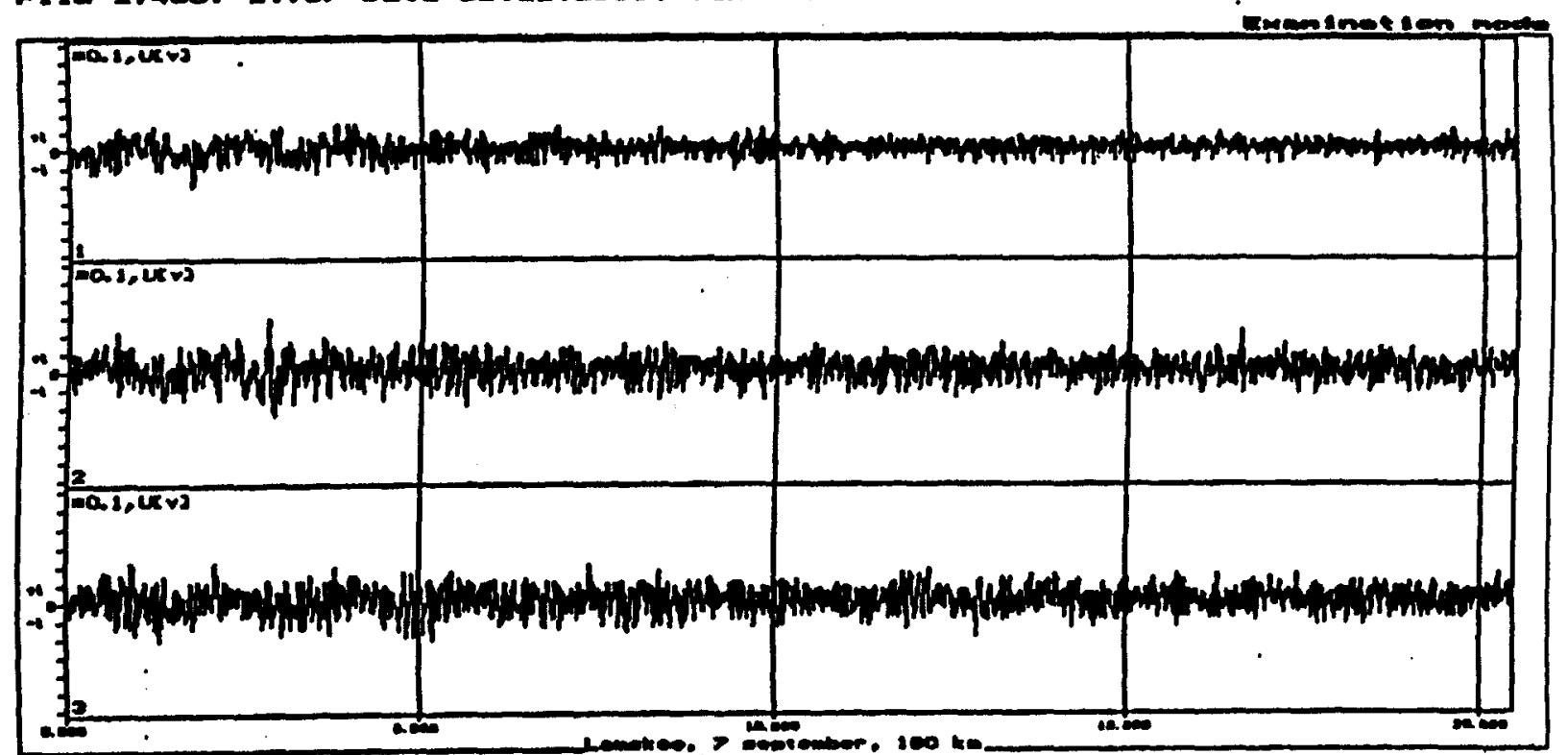

80 - IOO cer 


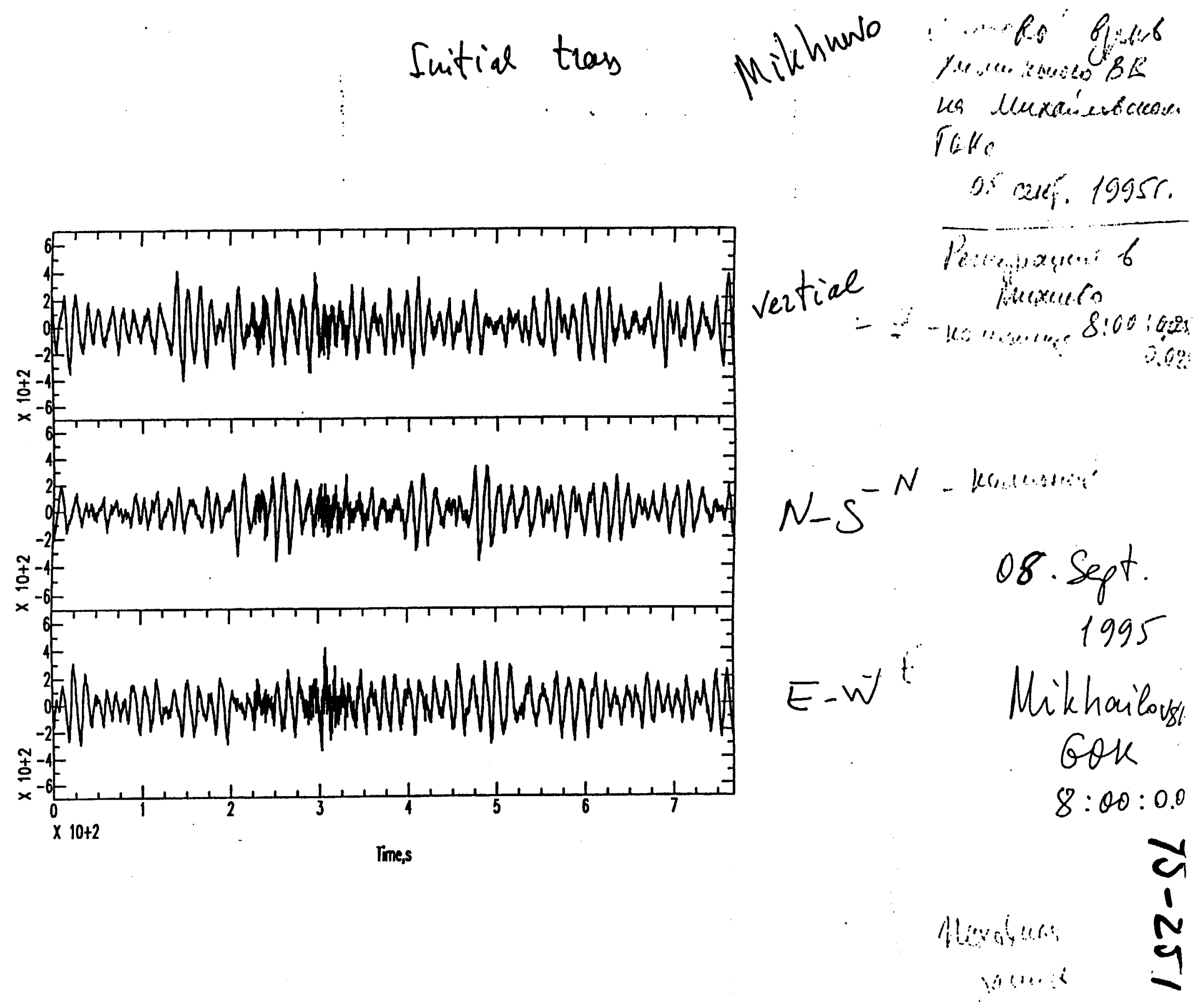


Explosion at Michailovsky GOK (Sept 08, 1195)

Point of registration: pos. Michnevo, $R=340 \mathrm{rm}$

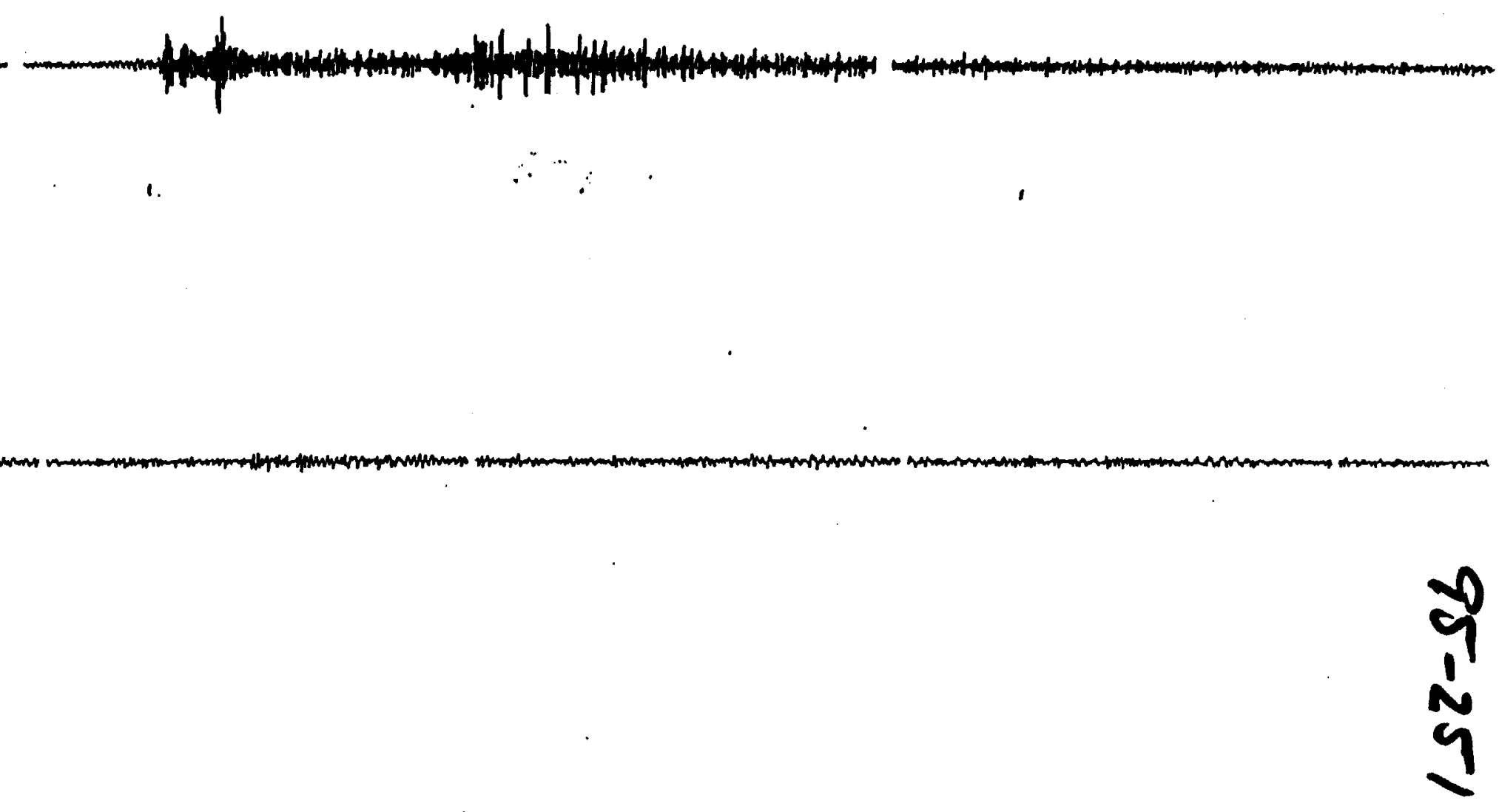

('s 
Byput wa lluwate Qs. 09.95

Rewappang in noc.

Sept 08.1995

$R=60 \mathrm{~km}$

file a301 date 95-9-8 tine 8:4:日. Y-ax $f .=$ ?.

$A \cup=3.983$ AuSq $=29.435$ AuA $=17.661 \quad D=2.7777$

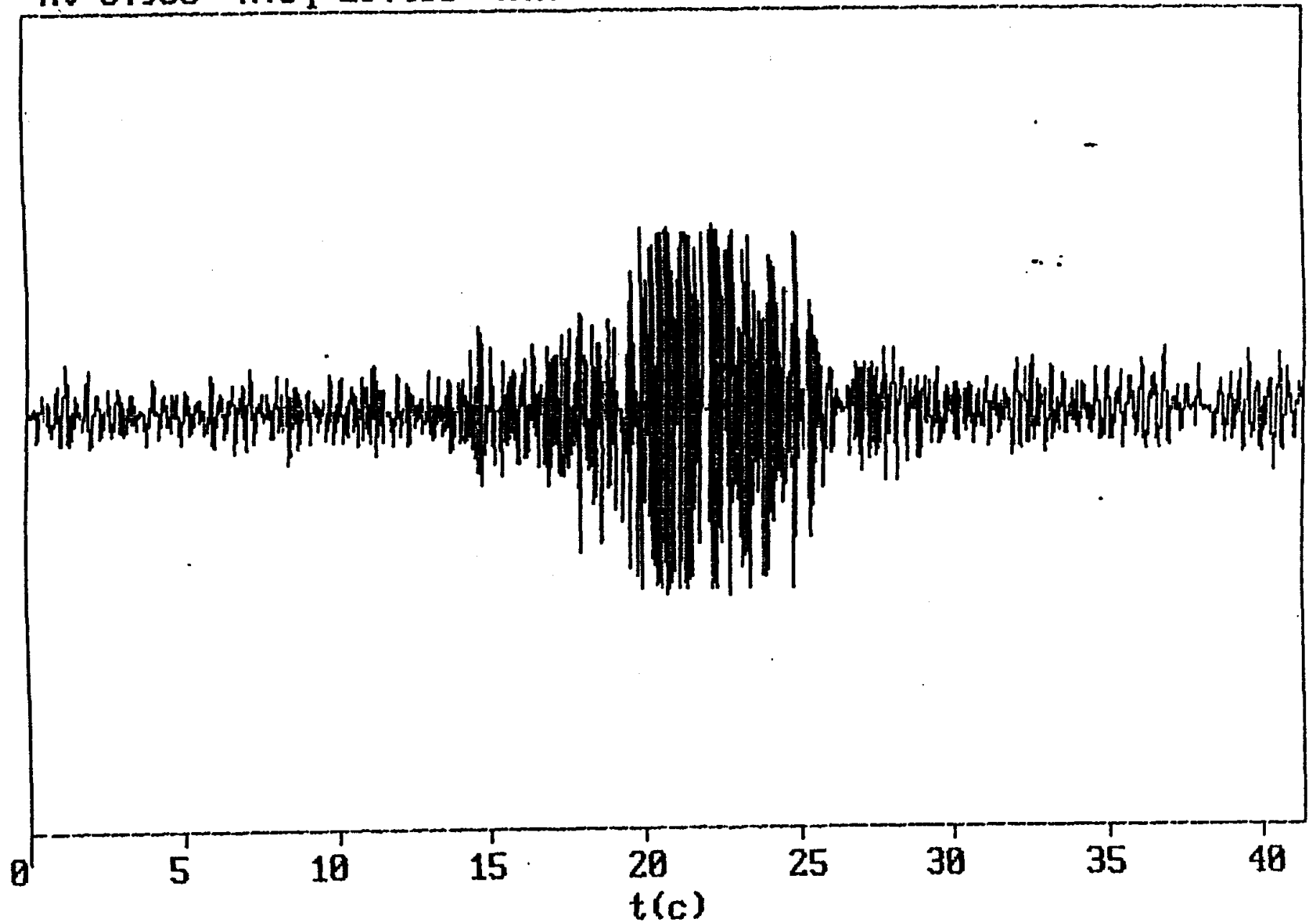

N.point $=4096$ s.point $=1$ Block $=0$ event $=1$ 


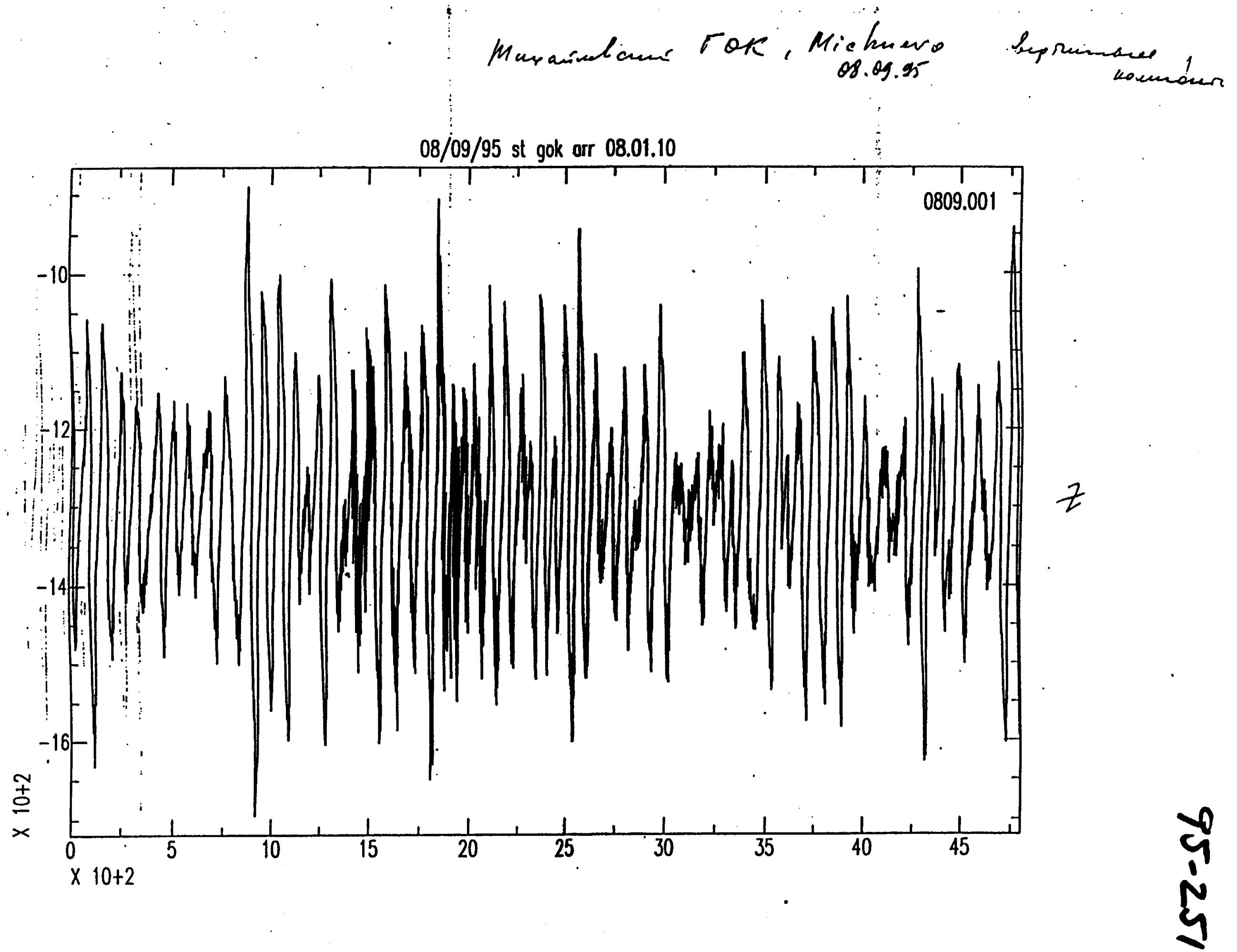




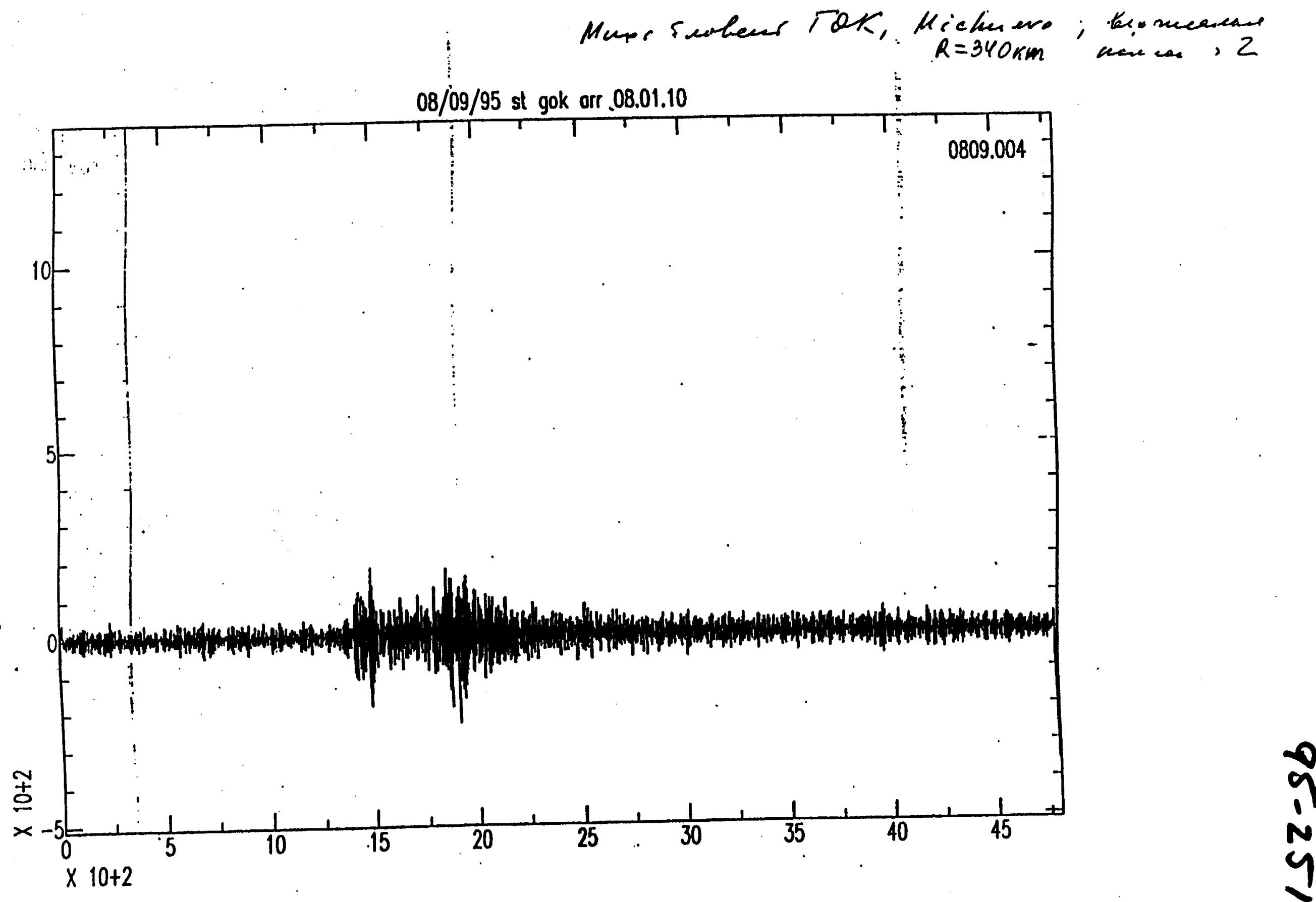

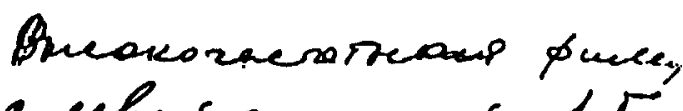
- echeer zpanment 15 
Mikhailusk

08.09.95

pos. Srabada

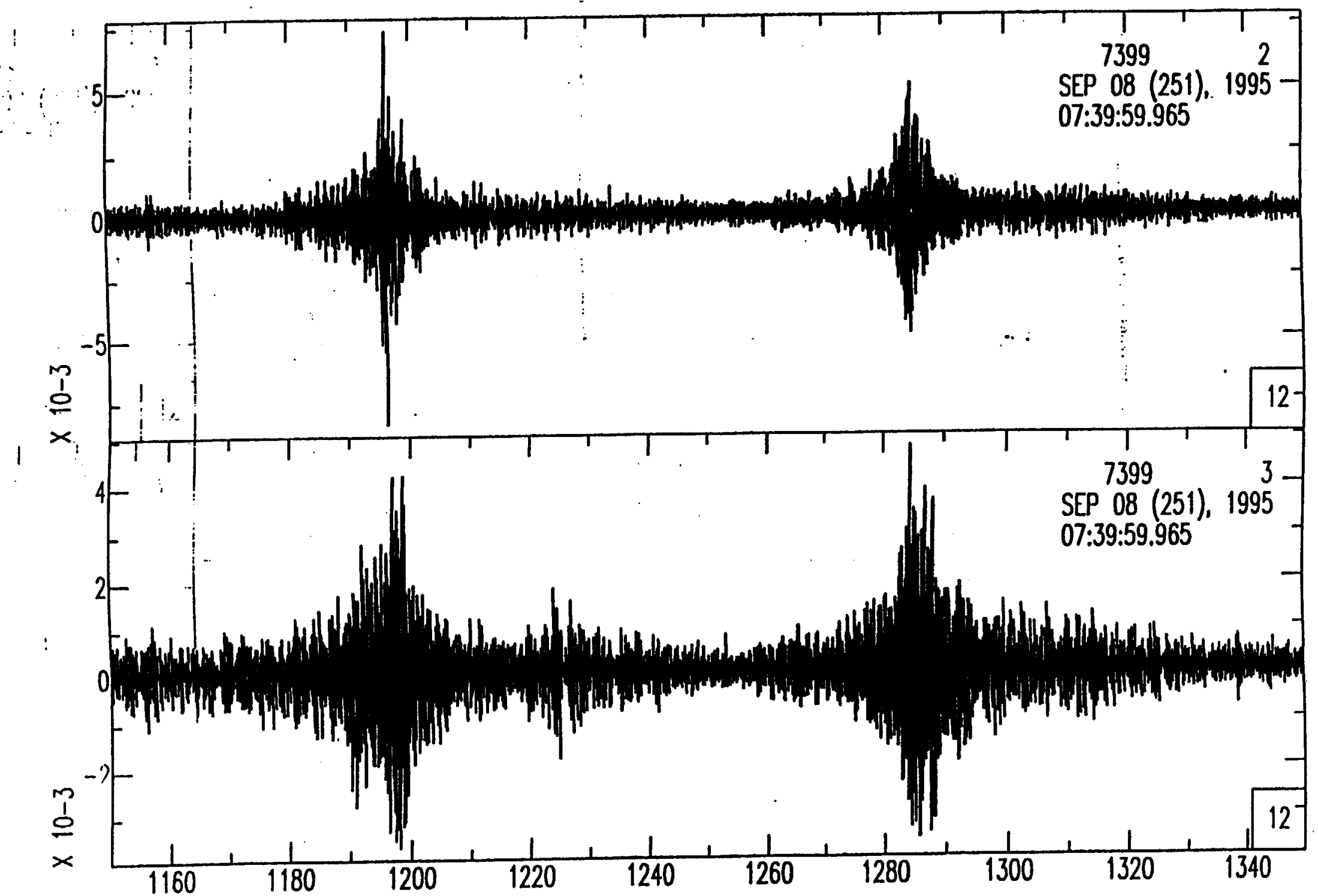

$x$-radial $y$-trausversal 


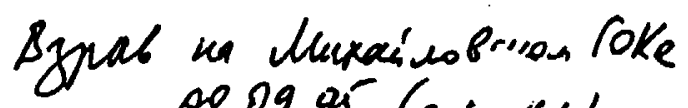
08.09.95 (2 a. ucus) Pecucuspayns b noc. Crovage.

file a301 date 95-9-8 time 8:4:0. Y-ax $f .=7$.

$A \cup=3.983 \quad A \cup S q=29.435 \quad A \cup A=17.661 \quad D=2.7777$

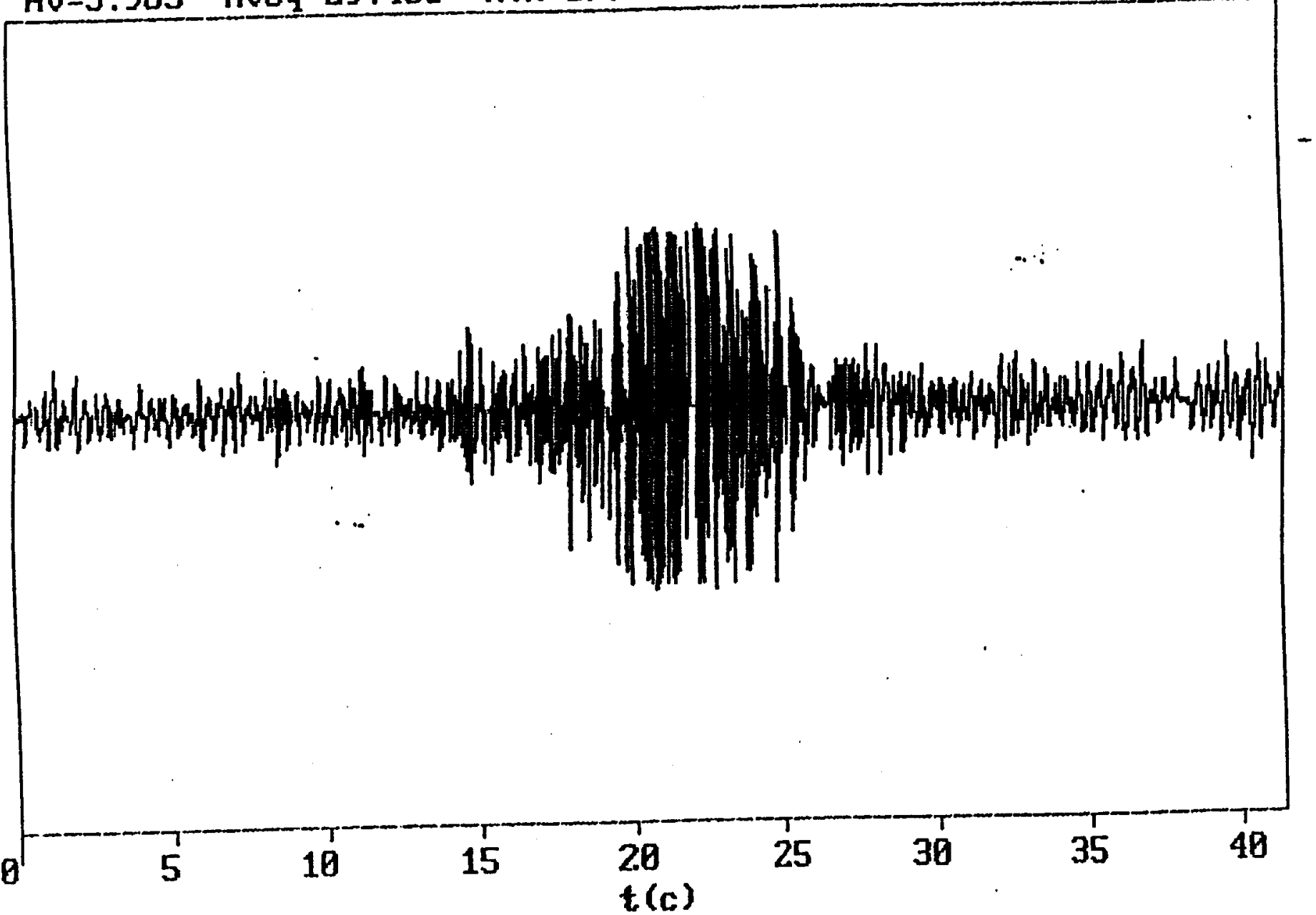

N.point $=4096$ S.point $=1$ Block=0 event $=1$ 
пос. Свобода, Курская обл. 08.09.1995 08 $04^{\prime} 00^{\prime \prime}$

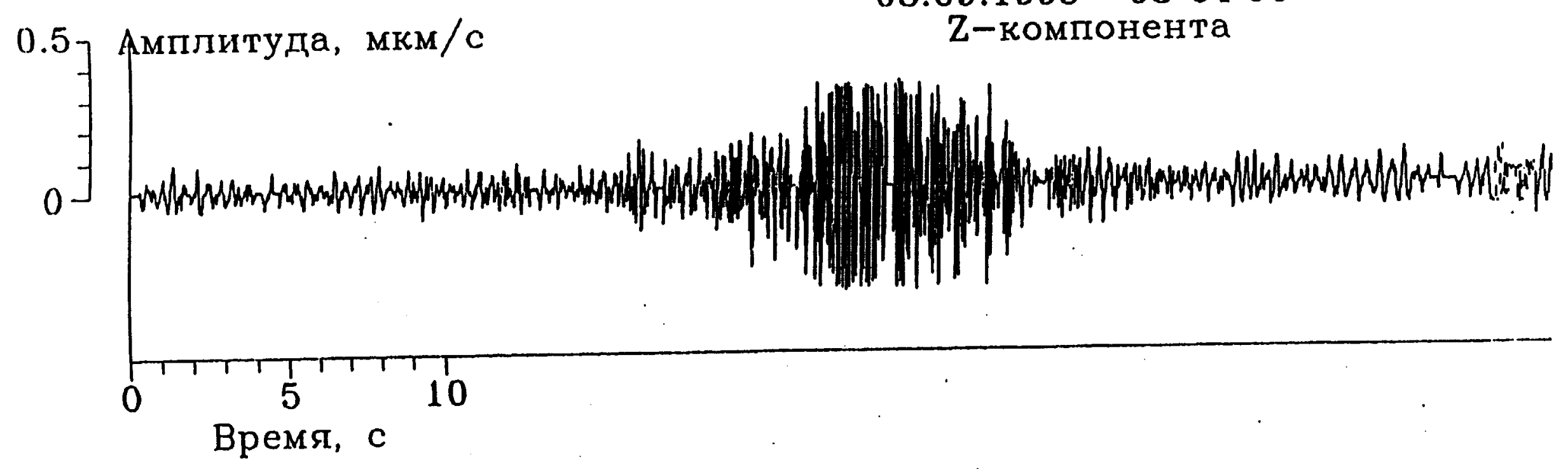




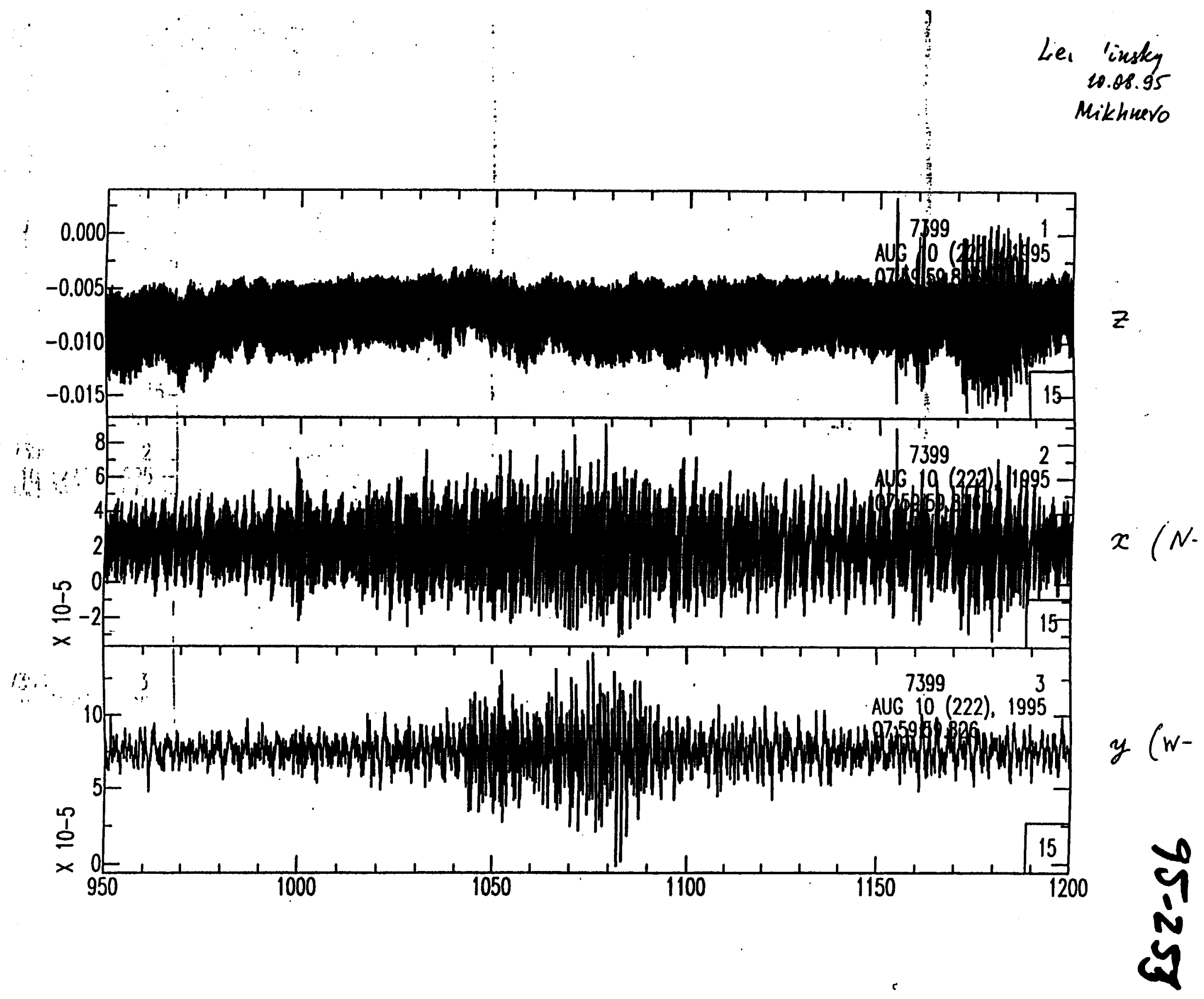




\section{Appendix 6: Nomogram used for determing magnitudes of the Kursk mining blasts}

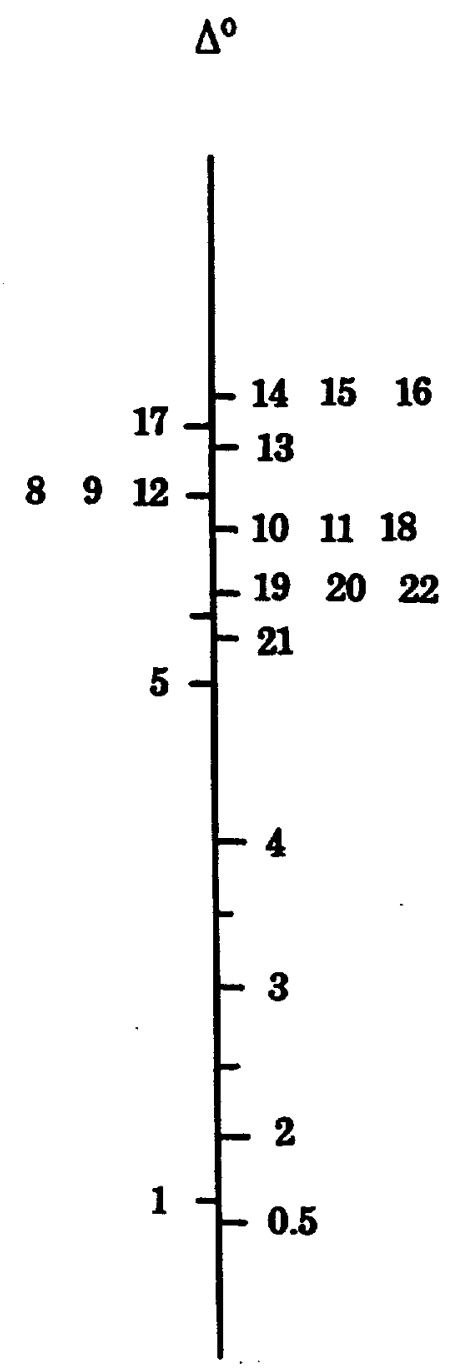

MPV

$A(\mu) \quad T(\sec )$

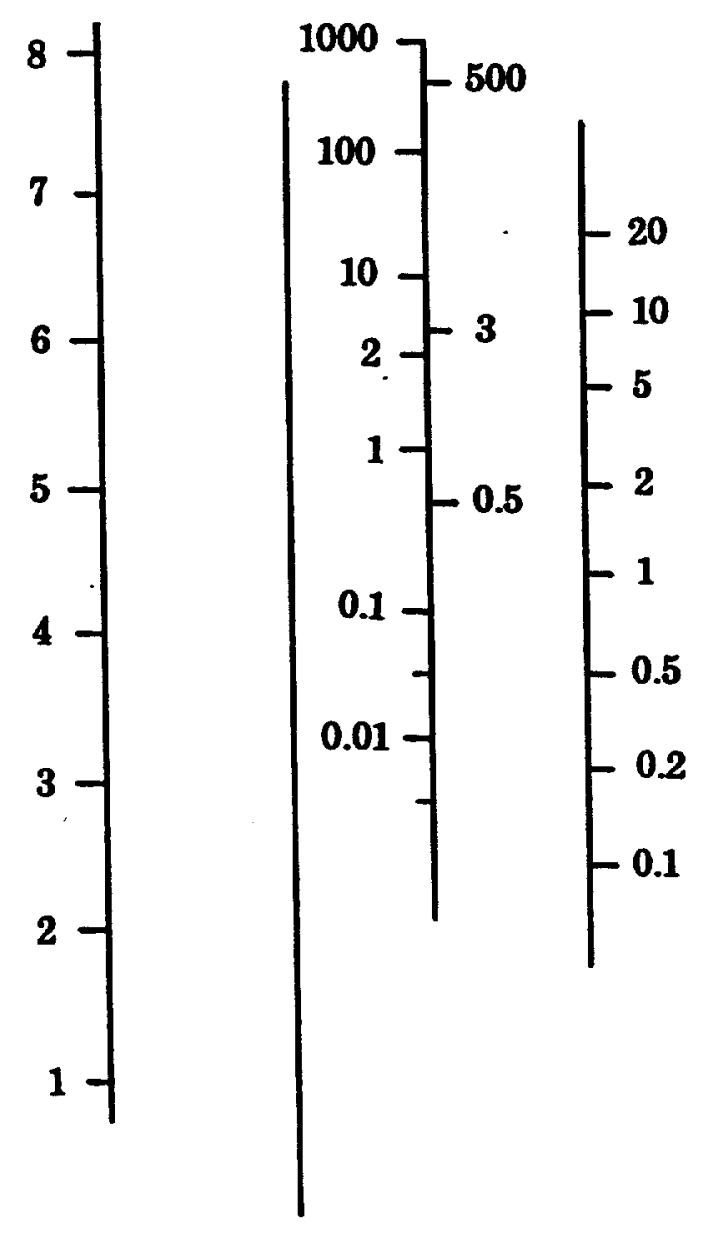




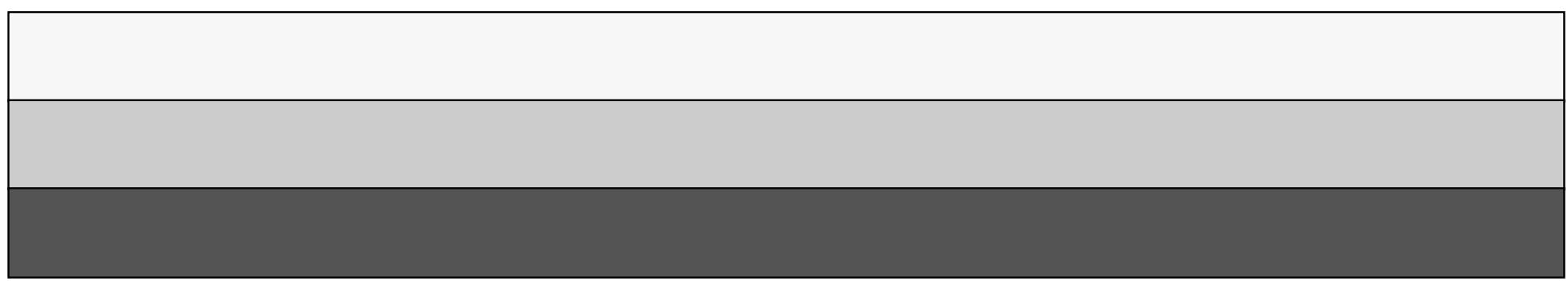

